DEPARTMENT OF THE INTERIOR

U.S. GEOLOGICAL SURVEY

\title{
MINERALOGY AND THERMAL PROPERTIES OF CLAY DEPOSITS IN THE SALT RANGE AND KALA CHITTA RANGE, PUNJAB PROVINCE, PAKISTAN
}

Gene Whitney ${ }^{1}$, Syed Qamar Abbas ${ }^{2}$, and Kenneth Esposito ${ }^{1}$

U.S. Geological Survey Open-File Report 90-657

Report prepared jointly by the Geological Survey of Pakistan and the U.S. Geological Survey under the auspices of the U.S. Agency for International Development.

This report is preliminary and has not been reviewed for conformity with the U.S. Geological Survey editorial standards and stratigraphic nomenclature.

1 U.S. Geological Survey, Box 25046, Denver Federal Center, Denver, Colorado 80225

2 Ministry of Petroleum and Natural Resources, Geological Survey of Pakistan, Lahore, Pakistan 54590 


\title{
MINERALOGY AND THERMAL PROPERTIES OF CLAY DEPOSITS IN THE SALT RANGE AND KALA CHITTA RANGE, PUNJAB PROVINCE, PAKISTAN
}

\author{
Gene Whitney, Syed Qamar Abbas, and Kenneth Esposito
}

\section{INTRODUCTION}

The Salt Range and Kala Chitta Range, Pakistan, contain many small deposits of laterite, bauxite, bentonite, and other economic clay deposits. Many of these deposits are located in remote and inaccessible areas and therefore have not been well studied or exploited. Others deposits have been very well characterized. The present examination of the clay deposits of the Salt Range and Kala Chitta Range was undertaken as part of a cooperative geological research program between the Geological Survey of Pakistan and the U.S. Geological Survey (Punjab Regional Framework Program), funded by the government of Pakistan and the U.S. Agency for International Development.

The purpose of this study is to provide an internally consistent mineralogical and thermal data set for a broad sampling of the clay deposits in the Salt Range and Kala Chitta Range, Punjab. Seventy-nine samples were collected from outcrop and mine exposures. Location of clay mineral leases obtained from the Directorate of Mineral Development are listed in Table 1 and are plotted on figures 1 through 5. These leases were used as a guide for field work and sampling. Clay types and the location of individual samples from the Salt Range are listed in Table 2. A brief description of each sample is included as Appendix I at the end of this report. Samples were analyzed in the U.S. Geological Survey's Clay Petrology Laboratory in Denver, Colorado. Some of the analyses were performed by the second author during his visit to the U.S. in November, 1989.

\section{ACKNOWLEDGEMENTS}

We are deeply grateful to Mr. Hamid Perraiz Chughtai, Joint Director, Directorate of Mineral Development, and his staff in Lahore for their great assistance in locating mineral leases in the Salt Range. We are also grateful to Peter Warwick, Ned Noble, and their USGS/USAID staffs for their considerable administrative and logistical assistance.

\section{GEOLOGY AND DESCRIPTIONS OF THE CLAY DEPOSITS IN THE SALT RANGE}

The deposits studied in the Salt Range and Kala Chitta Range, north central Pakistan, include bentonite, fireclay, China clay, laterite, and bauxite. In this paper we will follow the convention of referring to kaolinitic clay deposits according to their industrial use, rather than their specific mineralogy. Because all past work has followed this convention, comparison with previous studies is 
more convenient. Initial classification of each deposit was based on mineral lease information kindly provided by the Directorate of Mineral Development in Lahore.

\section{Bentonite:}

Bentonites are layers of various thickness composed mostly of smectitic clay. These smectite-rich layers are the result of devitrification and alteration of volcanic glass in an aqueous environment. If ash was allowed to remain undisturbed during and after alteration, the resulting bentonite would be very pure smectite and would contain little or no grit. Generally, however, there has been some reworking of material subsequent to deposition and the bentonite is contaminated with sand and silt. This grit, along with organic contamination, may reduce the industrial value of bentonite. The bentonites examined in the Salt Range are all thin, usually less than $25 \mathrm{~cm}$, and usually contain some contamination. The bentonites in the Salt Range lie almost exclusively within the Siwalik Group or Rawalpindi Group, primarily within the Nagri (Pliocene) and Kamlial (Miocene) Formations, which are exposed in the eastern and central Salt Range. These Tertiary rocks are highly disturbed at the eastern end of the Salt Range, making exposures of bentonite difficult to locate, discontinuous, and very difficult to mine. Bentonite occurrences in the central Salt Range and Potwar Plateau near Chinji village are more flat-lying, but remain thin and difficult to exploit because of thick overburden.

\section{Fireclay:}

Fireclay is clay material composed primarily of kaolinite (generally poorly ordered), but contains significant amounts of mineral impurities, particularly illite. Fireclay is used in low-grade refractory materials such as building brick, fire brick, tile, or stoneware. Fireclay is found predominantly in the Patala Formation (Paleocene) throughout the Salt Range. It is of sedimentary origin and is generally associated with coal. In some cases, the coal underclay is mined as fireclay. Some clay deposits in the Datta Formation (Lower Jurassic) have been classified as fireclay, but these materials are commonly shale or mudstone and are very impure.

\section{China clay:}

China clay is another kaolinite-rich clay product, but it is generally pure white kaolinite and does not contain the mineral and organic impurities that contaminate fireclay. China clay is used primarily for fine ceramics and for paper filler and coating. It generally forms by residual weathering or by hydrothermal alteration. Although Pakistan contains some significant China clay deposits in the Swat Valley, the Salt Range China clays are very limited in extent and of lower quality than the Swat clays. The only deposits classified as China clay in the Salt Range are tan to brown, though they are composed of fairly pure kaolinite.

\section{Laterites and bauxites:}

Laterites and bauxites are the most widespread and distinctive of the clay deposits in the Salt Range. Laterites are severely leached and weathered soils which consist primarily of hydrous oxides of iron and aluminum. Bauxite is a particular type of laterite in which aluminum has been concentrated and iron 
depleted. Generally, Salt Range laterite profiles contain both iron-rich and irondepleted zones. These lithologies are easy to identify in the field because of their bright white, red, and yellow colors. They are rarely of great volume or extent, being limited to a few meters in length or width on outcrop. Laterite in the Salt Range is commonly found in the basal Tertiary unit, the Hangu Formation (Paleocene). These laterites are sometimes, but not always, at the unconformity between Tertiary and Mesozoic or between Tertiary and Paleozoic rocks.

\section{METHODS OF ANALYSIS}

Clay samples were analyzed for mineralogy and thermal properties. Mineralogy was determined by grinding each sample in a ball mill until the powder passed a 200 mesh screen. Random specimen mounts were made of the resulting powder and analyzed using a Siemens D-500 automated X-ray diffractometer. Mineral composition was determined by comparison of data with the JCPDS mineral data file, and is listed in Table 3.

Thermogravimetric analysis was performed using a Perkin-Elmer TGS-2 thermogravimetric analyzer, automated with a Macintosh IIci computer, MacADIOS interface hardware, and LabVIEW software. Ten milligrams of each powdered sample was heated at $20^{\circ} \mathrm{C}$ per minute from $25^{\circ} \mathrm{C}$ to $1000^{\circ} \mathrm{C}$ in nitrogen atmosphere. Weight loss was accurately measured by monitoring the microbalance during heating, and the temperature of each weight loss event was accurately determined by identification of peaks on the first-derivative of the weight loss curve. Thermogravimetric analyses are included in Appendix II.

\section{SUMMARY OF ANALYTICAL RESULTS}

Bentonites from the Nagri Formation near Jalalpur (PK 2 and PK 3) are nearly pure smectite with only minor amounts of quartz (Figure 6). This material occurs in near-vertical veins 20 to $35 \mathrm{~cm}$ thick and is currently being mined by hand by local laborers. This highly smectitic material displays typical thermal behavior, losing almost $15 \%$ of its weight below $200{ }^{\circ} \mathrm{C}$, but losing only an additional $5 \%$ between $200{ }^{\circ} \mathrm{C}$ and $1000{ }^{\circ} \mathrm{C}$ (Sample PK-89-3 in Appendix II).

Fireclay in the Salt Range is composed chiefly of kaolinite, with lesser amounts of anatase, quartz, mica, and sulfate minerals (Figure 7). The highly kaolinitic fireclays exhibit distinctive thermal behavior losing very little weight from adsorbed moisture below $200^{\circ} \mathrm{C}$, but losing approximately $13-14 \%$ of their weight in a single dehydroxylation event at about $550^{\circ} \mathrm{C}$ (Sample PK-89-57 in Appendix II).

Bauxites and laterites vary widely in their mineralogical composition, depending upon the position in the weathering horizon from which the sample was taken, the composition of the parent rock, and the specific nature of the weathering conditions under which the weathered material formed (e.g., the lack or abundance of organic matter). Laterites are enriched in $\mathrm{Fe}$-bearing minerals formed under oxidizing conditions. These include hematite, goethite, lepidocrocite, and a variety of amorphous $\mathrm{Fe}$-oxides and oxy-hydroxides. The more aluminous varieties (bauxites) are predominantly boehmite, kaolinite, and gibbsite (Figure 8), but may contain a large number of minor phases such as 
anatase, calcite, and Fe-minerals. The thermal behavior of these complex mixtures of minerals is likewise complex and TGA analysis reveals a number of weight loss events. For example, bauxite from the Salt Range (Sample PK-89-38 in Appendix II) exhibits a double weight-loss event around $300^{\circ} \mathrm{C}$ which corresponds to goethite and/or lepidocrocite dehydroxylation. Boehmite and kaolinite both break down at around $550{ }^{\circ} \mathrm{C}$, so a large dehydroxylation event is seen there. At higher temperatures, calcite and sulfates decrepitate. The weight loss associated with the breakdown of calcite and loss of $\mathrm{CO}_{2}$ is at about $700{ }^{\circ} \mathrm{C}$.

Bauxites and fireclays of the Kala Chitta Range differ mineralogically from those in the Salt Range. Instead of boehmite and gibbsite, which dominate the Salt Range bauxites, the Kala Chitta Range samples are composed primarily of diaspore and bayerite (Figure 9). Anatase persists, but no carbonates were identified in the Kala Chitta Range bauxites. Rather, sulfates were common. In addition, the Fe-rich laterites in the Kala Chitta Range contained foliated hematite rather than massive goethite or lepidocrocite observed in the Salt Range samples.

\section{CLAYS AS INDICATORS OF THERMAL REGIME}

Clays and related oxide and hydroxide minerals may serve as sensitive indicators of diagenetic or metamorphic grade. In the present context, both smectitic bentonites and the laterite/bauxite horizons enriched in $\mathrm{Fe}$ - and $\mathrm{Al}$ hydroxides may be used as indicators of thermal regime.

When smectite is exposed to temperatures in excess of about $60^{\circ} \mathrm{C}$, it begins to react toward illite via an interstratified intermediate phase (Hoffman and Hower, 1979; Whitney and Northrop, 1988). Absence of a reaction in smectitic materials ordinarily indicates that the rocks have never been heated above $60{ }^{\circ} \mathrm{C}$ for any length of time. Bentonites in both the Salt Range and in the Kala Chitta Range remain smectitic; there is no sign of reaction. This lack of diagenetic reaction confirms what is accepted about the geology of these rocks, that neither the Salt Range bentonites nor the Kala Chitta Range bentonites have experienced deep burial or high temperatures. Though the Salt Range bentonites are highly deformed, their presence in the young molasse sediments of the Tertiary Siwalik Group suggests that they have never been buried for geologically long periods of time at elevated temperatures. In the Kala Chitta Range, the bentonites actually occur just north of the range itself, lying within very young and undeformed fluvial sediments. There is clearly no evidence for significant burial or smectite diagenesis in the Kala Chitta Range bentonites. Thus, the bentonites simply indicate a lack of burial and consequent heating.

A comparison of mineral composition of bauxites and laterites from the Salt Range (boehmite + gibbsite) and Kala Chitta Range (diaspore) allows us to compare the thermal histories of the two environments in a general way. The Alhydroxides in bauxites, which form at low temperature $\left(25^{\circ} \mathrm{C}\right.$, weathering conditions), are primarily gibbsite and boehmite. Though diaspore has been reported in low-temperature environments, it is more commonly associated with high temperatures. Thermal alteration of bauxite causes the gibbsite and boehmite to react to diaspore. The precise transition temperature is a matter of debate and depends upon several variables, but the reaction of gibbsite to boehmite occurs near $120^{\circ} \mathrm{C}$, and the reaction of boehmite to diaspore normally occurs 
between $200{ }^{\circ} \mathrm{C}$ and $300{ }^{\circ} \mathrm{C}$ (Valeton, 1972). Furthermore, the transition from goethite to hematite occurs near $100^{\circ} \mathrm{C}$. These reactions are too complex to use as simple or precise geothermometers, but the presence of diaspore indicates metamorphism of the buried and deformed bauxites in the Kala Chitta Range, when compared to equivalent rocks in the Salt Range (e.g., the Jurassic Datta Formation).

\section{SUMMARY}

The deposits of clay in the Salt Range and Kala Chitta Range, north central Pakistan, are commonly small and of local economic value. They consist of bentonite deposits in Tertiary and Recent sediments, fireclay in Jurassic and Tertiary sediments, and bauxite/laterite primarily in Permian, Jurassic or Paleocene rocks. The bentonites are all highly smectitic, though commonly contaminated, and show no sign of burial metamorphic affects in either the Salt Range or in the area just north of the Kala Chitta Range. Evidence for burial metamorphism is seen in the bauxites and laterites through the reaction of lowtemperature minerals such as gibbsite, boehmite and goethite to higher temperature minerals such as diaspore and micaceous hematite. 


\section{REFERENCES}

Abbas, S.H. and Hasan, M. (1984) Laterite/laterite-bauxite deposits of Karuli-Choa Saiden Shah area, Salt Range, Jhelum district: Geological Survey of Pakistan Information Release No. 237.

Ali, S.T. and Shah, I. (1963) The bentonite resources of Pakistan: CENTO Symposium on Industrial Rocks and Minerals, Lahore, Pakistan, p.153-160. Alauddin, M., Qaiser, M.A., Akhtar, S.M., and Khan, A.H. (1965) Mineralogy and chemistry of Dheri-Kot clays, Campbellpur (Attock) district, Rawalpindi Division, Punjab: Pakistan Journal of Scientific and Industrial Research 8, 343346.

Ashraf, M., Ahmad, M., and Faruqi, F.A. (1976) Jurassic bauxite and kaolinite deposits of Chhoi area, Kala Chitta Range, Punjab: The Geological Bulletin of the Punjab University 12, 41-54.

Ashraf, M., Chohan, N.A., and Faruqi, F.A. (1972) Bauxite and clay deposits in the Kattha area, Salt Range, Punjab, West Pakistan: Economic Geology 67, 103-110.

Ashraf, M., Qureshi, W., and Faruqi, F.A. (1972) Preliminary studies on the economic geology of bauxite/laterite deposits, Kattha area, Salt Range, Punjab, Pakistan: The Geological Bulletin of the Punjab University 9, 43-53.

Baqri, S.R.H. and Iqbal, N. (?) Distribution of clay minerals in Patala Shales, exposed at Nammal Gorge: Pakistan Museum of Natural History (P.S.F.), Islamabad.

Beg, M.A. and Faruqi, F.A. (1962) China clay from Salt Range area: Pakistan Journal of Scientific and Industrial Research 5, 91-93.

Cheema, M.R. (1974) Bauxite and clay deposits of part of the Kattha area, Khushab Tehsil, Sargodha district, Punjab: Geological Survey of Pakistan Information Release No. 76.

Faruqi, F.A. (1966) Mineralogical and ceramic investigations on a high alumina clay from Skesar Hills: Pakistan Journal of Scientific and Industrial Research 9, 146-149.

Faruqi, F.A. (1967) Clay minerals: Pakistan Journal of Scientific and Industrial Research 5, 542-549.

Faruqi, F.A. (1970) Mineralogical studies on some high alumina bauxitic clays from Salt Range area: Pakistan Journal of Scientific and Industrial Research 13, 185188.

Faruqi, F.A. (1972) X-ray studies on two bauxitic ores from Kattha, Punjab: Pakistan Journal of Scientific and Industrial Research 15, 131-133.

Hoffman, J., and Hower, J. (1979) Clay mineral assemblages as low grade metamorphic geothermometers: Application to the thrust faulted disturbed belt of Montana, U.S.A.: in Aspects of Diagenesis, P.A. Scholle and P.R. Schluger, eds., . Soc. Econ. Paleontol. Mineral. Spec. Publ. 26, 55-79.

Hussain, T. and Khan, A.L. (1969) Fireclay deposits of Kalachitta Range, District of Campbellpur, West Pakistan: Geological Survey of Pakistan, P.P.I. No. 89.

Hussain, T. and Naqvi, A.A. (1972) High alumina clay deposits of the Punjab Province, Pakistan: Geological Survey of Pakistan Information Release No. 59.

Hussain, T. and Sibghat, U. (1966) Interim geological report on fire clay deposits of the Salt Range: Geological Survey of Pakistan, P.P.I. No. 31. 
Ibrahim, M., Rashid, A. Z., and Iqbal, M. P. (1975) A study of Kala-Chitta and Salt Range clays: Pakistan Journal of Scientific Research 27, 49-55.

Kazmi, A.H. and Safdar, M. (1962) Clay resources of West Pakistan: CENTO Symposium on Industrial Rocks and Minerals, Lahore, p.120-131.

Khan, S.N. and Hussain, A. (1970) Mineralogy and physical properties of bauxite high alumina clay deposits of Katha-Pail area, Tehsil Khushab District, Sargodha, Punjab: Geological Survey of Pakistan Information Release No. 37.

Khan, S.N. (1971) Bauxite and clay deposits of Chamban-Wala Mohar area, Sargodha District (Punjab), Pakistan: Geological Survey of Pakistan Information Release No. 39.

Safdar, M., Hamid, A., and Naz, M. A. (1966) A study of a high alumina clay from Musakhel: Pakistan Journal of Scientific and Industrial Research 9, 224-229.

Valeton, I. (1972) Bauxites: Elsevier Publishing Company, Amsterdam, 226 pp.

Whitney, G. and Northrop, H. R. (1988) Experimental investigation of the smectite to illite reaction: Dual reaction mechanisms and oxygen-isotope systematics: Amer. Mineral. 73, 77-90. 


\section{APPENDIX 1 \\ SAMPLE DESCRIPTIONS}

PK-89- 1: Bentonite.

Dark grey to black, soapy feel. Bentonite is 7" to 13 " thick, pinching and swelling. Layer has undulating surface and lies within Nagri Formation (Pliocene) sandstone. Bentonitic material appears to be reworked but fairly pure. This sample was taken from a small mine $\left(25^{\prime}\right.$ deep). Strike $=\mathrm{N} 80^{\circ} \mathrm{W}, \operatorname{dip}=$ $45^{\circ} \mathrm{NE}$.

PK-89- 2-3 Bentonite.

PK-89- 2: Dark grey bentonite

PK-89- 3: Light grey bentonite

Samples taken from 90-100' deep mine near Jalalpur in the Shah Kamir area $(43 \mathrm{H} / 6)$. Bentonite layer is $10^{\prime \prime}$ to $14 "$ thick. The light grey portion of the bentonite is about $2 "$ thick and appears to be primary. The thicker, dark grey layer above it appears to be reworked. Bentonite is in the Nagri Fm. and is underlain by a chocolate brown claystone and overlain by greenish grey siltstone. Strike $=\mathrm{S} 80^{\circ} \mathrm{W}, \operatorname{dip}=52^{\circ} \mathrm{SE}$.

PK-89- 4-10 Bauxite and laterite.

PK-89- 4: Massive, earthy red-brown lateritic material

PK-89- 5: Bauxitic material, massive grey matrix with brown pisolites

PK-89- 6: Bauxitic material, massive black matrix with brown pisolites

PK-89- 7: Red, massive, highly fractured lateritic material

PK-89- 8: Dark grey, brittle claystone with Fe-oxide staining

PK-89- 9: White, bleached, massive claystone with pink breccia-like fragments

PK-89- 10: Carbonate parent material, weathered, yellow-ochre staining

Outcrop is near Pind Savika (43 H/5). Some bauxite has been mined at this locale. The bauxite/laterite is in the Hangu Fm. (Paleocene), which has been faulted onto the younger Murree Fm. (Miocene) at this location. Strike $=\mathrm{S} 60^{\circ} \mathrm{E}$, $\operatorname{dip}=50^{\circ} \mathrm{SW}$.

PK-89- 11-12 Fireclay

PK-89- 11: Fireclay, yellowish grey, limonite staining, carbonaceous staining.

PK-89- 12: Reddish to yellowish grey, plastic, gypsiferous (?).

Samples were taken from an abandoned coal mine in the Waralah area, on the way to Kalarkahar (43 D/14). Samples are from the lower Patala Fm.

(Paleocene). Mine is only 10-15' deep. 
PK-89- 13-17 Laterite

PK-89- 13: Soft, yellow-ochre layer, fissile with dark staining along laminae

PK-89- 14: Light yellow-gray claystone with iron staining

PK-89- 15: Ferruginous claystone, hematite veins and staining

PK-89- 16: Pisolitic laterite (16' thick), massive and jointed

PK-89- 17: Dark reddish-brown, friable silty ferruginous clay

Samples are from the Hangu Fm. lying between the Sardhai Fm. (Permian) and the Patala Fm. (Paleocene). Location is at Rakh Simbli, near Karuli (43 D/14). Taken from an abandoned mine. Dark red clay was formerly mined as fireclay. Strike $=\mathrm{EW}, \operatorname{dip}=60^{\circ} \mathrm{S}$.

PK-89- 18 China clay

PK-89- 18a: Massive gray or white, waxy, with some red hematite staining

PK-89- 18b: (same as 18a)

Taken from a small abandoned adit near Rakhi Simbli about 0.5 mi. west of site of PK-89- 13-17 above. These samples lie downsection from the laterite/bauxite horizon of the Hangu Fm.

PK-89- 19 Fireclay

PK-89- 19: Dull gray, waxy and friable clay layer

Samples were taken from the dump of a closed (locked) fireclay mine southwest of Rattuchah ( $43 \mathrm{H} / 2)$. Mine is in the Patala Fm. (Paleocene).

PK-89- 20-26 Laterite

PK-89- 20: White, massive waxy claystone with vertical hematite veinlets

PK-89- 21: Dark red, pisolitic laterite

PK-89- 22: Friable, variegated sandstone/siltstone

PK-89- 23: Light gray, hematite stained, thinly bedded sandstone

PK-89- 24: Massive white siltstone with $1 \mathrm{~cm}$ thick hematite veins

PK-89- 25: White sandstone with vertical hematite veins

PK-89- 26: Massive, yellow-white crossbedded sandstone, hematite stained

Samples are from a broadly excavated abandoned mining site one mile south of Wehali Zerin village ( $43 \mathrm{H} / 1$ ). Laterite lies within the Hangu Fm.

(Paleocene), which lies upon the Warchha Sandstone (Permian). Strike $=$ EW, dip $=10^{\circ} \mathrm{S}$.

PK-89- 28 Fireclay

PK-89- 28: Dark green, massive, waxy clay

Sample is from 150'-180' within coal mine at Chailab dal, north of Kot Bahadar Khan (43 H/1). Samples were taken from the Patala Fm. (Paleocene). 
PK-89- 29-33 Laterite

PK-89- 29: Mottled gray sandstone, thinly laminated with hematite staining PK-89- 30: Earthy gray claystone, hematite staining

PK-89- 31: Laterite, massive, dark brown and black with vertical fractures PK-89- 32: Massive, hard, olive green claystone

PK-89- 33: Bauxite, maroon and white, massive and fractured, hematite veins

This locality is in the Chanbanwala Mohar area near Chamil, on the Koushab-Chakwal road. Known as the Katha Pail bauxite deposit. Samples were taken from the mouth of an abandoned mine. Lower unit is Wargal limestone and upper unit is the Patala Fm. (Paleocene). Strike $=$ N35 ${ }^{\circ}$, dip $=10-15^{\circ} \mathrm{NW}$.

\section{PK-89- 34-39 Laterite/bauxite}

PK-89- 34: Clay layer superimposed upon bauxite

PK-89- 35: Massive white bauxite, 15" thick

PK-89- 36: White, Fe-stained, pisolitic bauxite

PK-89- 37: Iron laterite, dark red upper zone

PK-89- 38: Iron laterite, middle zone, pisolitic (sometimes absent)

PK-89- 39: Iron laterite, lower zone, patchy light red, tan, sharp contact with underlying limestone

From the Arara area, near Katha Masral (43 D/6). Samples taken from the face of a mine (approx. 60' deep). Deposits lie upon the Wargal limestone (?) at the Paleozoic-Tertiary unconformity.

PK-89- 40-41 Bentonite

PK-89- 40: Green-gray waxy bentonite with limonite staining

PK-89- 41: Light green, waxy bentonite

Sampling locality is NE of Bhilmar along the Chinji-Qadirpur road (43 D/6). Samples were taken from 20-30' within an abandoned bentonite mine. Deposit is in the middle part of the Nagri Fm., Siwalik Group (Late Mio-Pliocene). Strike = $\mathrm{N} 45^{\circ} \mathrm{E}, \operatorname{dip}=16^{\circ} \mathrm{NW}$.

PK-89- 42 Bentonite

PK-89- 42: Bentonite waste from tailings pile at abandoned mine

This bentonite deposit had been mined out several years previous. The deposit was flat-lying and lay beneath 5-6' overburden, east of Qadirpur (43 D/6). The deposit was presumably at the same horizon as samples PK 40 and 41.

PK-89- 43 Bentonite

PK-89- 43: Light gray, waxy bentonite with hematite staining 
NE of Chitta Parwar Nala, Subkur area. Deposits known locally as the Bhadrar bentonites. Sample taken from 20-30' in an abandoned mine. Deposit lies within the upper Kamlial Fm. (Miocene).

PK-89- 44-47 Fireclay

PK-89- 44: Lateritic claystone, brown, Fe-stained, fractured

PK-89- 45: Hard, white, massive claystone, grades down into gray-maroon claystone

PK-89- 46: Sandy white claystone from near top of "fireclay" horizon

PK-89- 47: Friable, hard, brown claystone near bottom of "fireclay" horizon

Samples taken from a small mine near Mousabazar, Narukhel area east of Musakhel (38 P/14). Clay horizon is in the Datta Fm. (Jurassic). Strike $=\mathrm{N} 45^{\circ} \mathrm{W}$, $\operatorname{dip}=35^{\circ} \mathrm{NE}$.

PK-89- 48 Fireclay and "high alumina" clay

PK-89- 48: High alumina clay, maroon, thick-bedded, possibly detrital

Taken from an active open-pit mine at Chattuwala Nala near Musakhel (38 $\mathrm{P} / 14$ ). Productive layer is about 12' thick and lies within the Datta Fm. (Jurassic).

PK-89- 49-52 Laterite

PK-89- 49: Red lateritic material, variegated and somewhat pisolitic

PK-89- 50: Soft, punky pisolitic clay with limonite staining

PK-89- 51: Hard, white sandstone, very coarse grained

PK-89- 52: Fireclay zone. Gray, waxy clay with red or maroon lenses.

Samples taken from NE of Chabil (38 P/14) along the Mianwali-Talagang road. Samples are from outcrop. Deposit is in the Datta Fm. (Jurassic) and has been mined intermittently.

PK-89- 53 Bauxite

PK-89- 53: Pisolitic white bauxite

Sample taken from the mouth of a very deep mine in the Datta Fm.

PK-89- 54 Fireclay

PK-89- 54: Massive, dark gray, dull clay with hematite staining.

Taken from northwest of Rikkhi, in Mianwali District (38 P/14). Samples removed from the dump of an abandoned clay mine.

PK-89- 55-56 Fireclay 
PK-89- 55: Fireclay, massive, dull gray, not bedded or fractured

PK-89- 56: Fireclay, dark gray, strongly bedded

Taken from Kharwag Nala near Burikhel (38 P/14). Samples were retrieved from a mine dump from abandoned mine in the Datta Fm. (Jurassic). PK-89- 57-58 China clay and fireclay

PK-89- 57: Light tan to buff clay, minor hematite staining

PK-89- 58: Massive, light gray fireclay Nala.

Samples retrieved from an active mine in the Datta Fm. (Jurassic) at Sirin

PK-89- 59-61 Fireclay, "high alumina" clay

PK-89- 59: Light gray, plastic, massive, soft and thick bedded

PK-89- 60: Soft, white material in thin (1-2") veins

PK-89- 61: Black, thin-bedded, fissile and shaley claystone

Material taken from an active mining locality east of Thatti village, along the Mianwali-Kalabagh road (38 P/14). These deposits lie within the Datta Fm. (Jurassic).

PK-89- 62 Fireclay

PK-89- 62: Gray, silty, laminated claystone

Sample taken from Kuch Tandar Khel area, 3-6 miles north of Kalabagh (38 $\mathrm{P} / 9$ ). This area has been leased for mining but little good quality clay has been located. Deposits are in the highly deformed Datta Fm.

PK-90- 1-5 Fireclay

PK-90- 1: Dense, massive, light grey fireclay

PK-90- 2: Ferruginous claystone, mottled red, brown, purple

PK-90- 3: Soft white-pink claystone

PK-90- 4: Highly ferruginous ironstone, dark brown, massive

PK-90- 5: Yellow to reddish-brown bauxite

Samples taken from active and abandoned open-pit mines near Surg and Narian. All samples are from the Jurassic Datta Formation. Rocks in this area are folded and steeply dipping in places.

PK-90- 6-9 Bentonite

PK-90- 6: Dull white, soapy bentonite with black specks (biotite?)

PK-90- 7: Dark green to gray bentonite with shiny fracture surfaces

PK-90- 9: Dark green to light green or brown bentonite 
All of these samples were taken from bentonite mines near the village of Dheri Chohan. Sample 6 was taken from the mouth of an inactive mine SE of Dheri Chohan. Samples 7 and 8 were taken from working face approximately 120 $\mathrm{ft}$ inside an active bentonite mine. The bentonites here are overlain by Recent or subrecent sediments. Sample 9 was taken from the dump of an active bentonite mine overlooking Shakardara Nala north of the village across the river.

PK-90- 10-11 Laterite

PK-90- 10: Ferruginous laterite, dark gray to brown to black

PK-90-11: Mottled green claystone with hematite staining

Samples taken from an active mine pit at Sakhi Zindpir area near Akhori. The exposed Datta Fm. is dark brown to black and highly foliated or schistose. Rocks are highly deformed and slickensides are common. Has the appearance of metamorphosed laterite.

PK-90- 12-13 Fireclay

PK-90- 12: Light gray claystone, shiny luster, talc-like feel

PK-90-13: Purple ferruginous foliated claystone

From mine near Jhod Wali. The Datta Fm. is highly deformed, foliated and faulted here. The highly schistose appearance of these rocks and the obvious structural deformation suggests metamorphosed laterites or bauxites.

PK-90- 14-17 Fireclay

PK-90-14: Light gray to creamy white claystone, well indurated (flint clay?) PK-90- 15: Friable, loosely cemented, off white to dull gray clay with no grit PK-90-16: White to pale green, earthy, friable clay

PK-90- 17: Well indurated, banded ferruginous claystone

These samples were taken from the working faces of mines operated by PUNJMIN near Nawa, 6-7 km south of the main Attock-Fateh Jang road. Mining activity is proceeding in several pits. The best fireclay (samples 15 and 16) are from mine N-2. Approximately 6-7 truck loads of clay are mined by hand each day and transported to Gujranwala for ceramic use. 
APPENDIX II: Thermogravimetric data for Pakistan clays: upper curve represents weight loss curve (in weight percent) and lower curve is the first derivative of weight loss, indicating temperature and magnitude of weight loss events. 


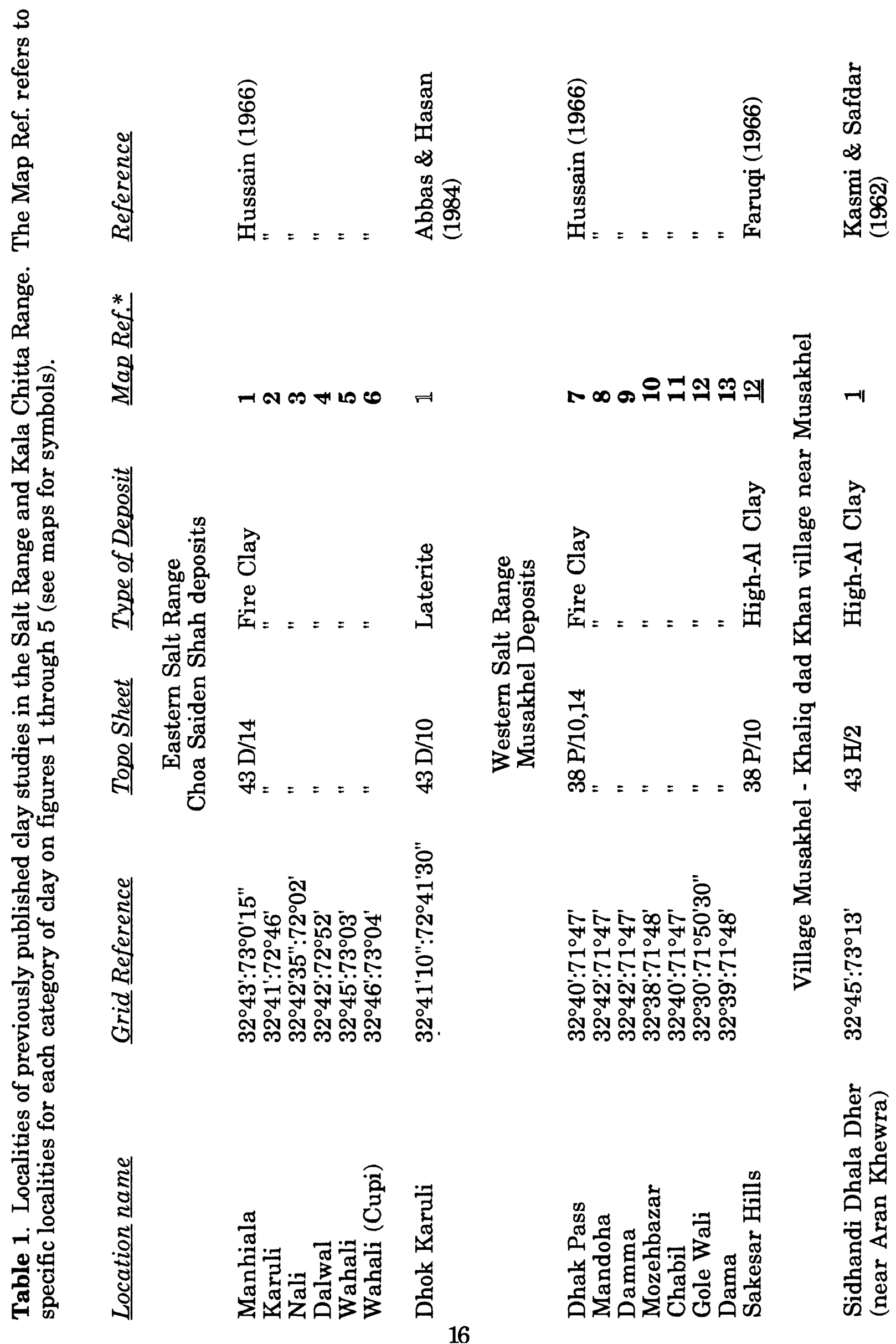




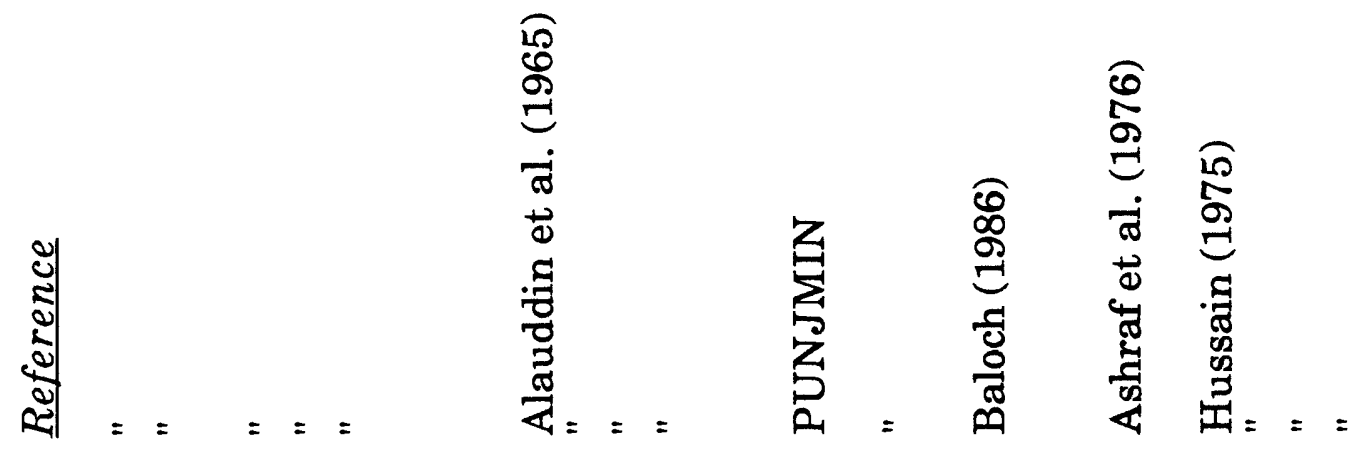

*.।

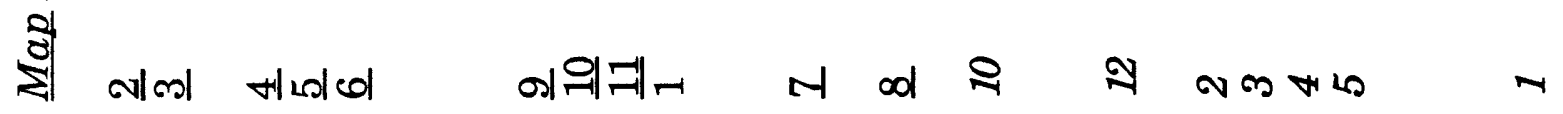<smiles>C#CC1CCCO1</smiles>

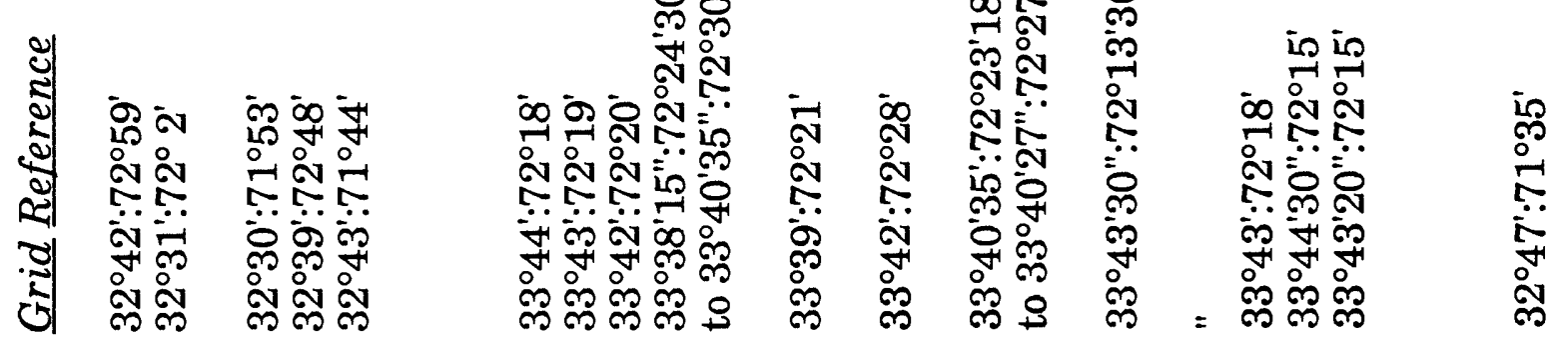
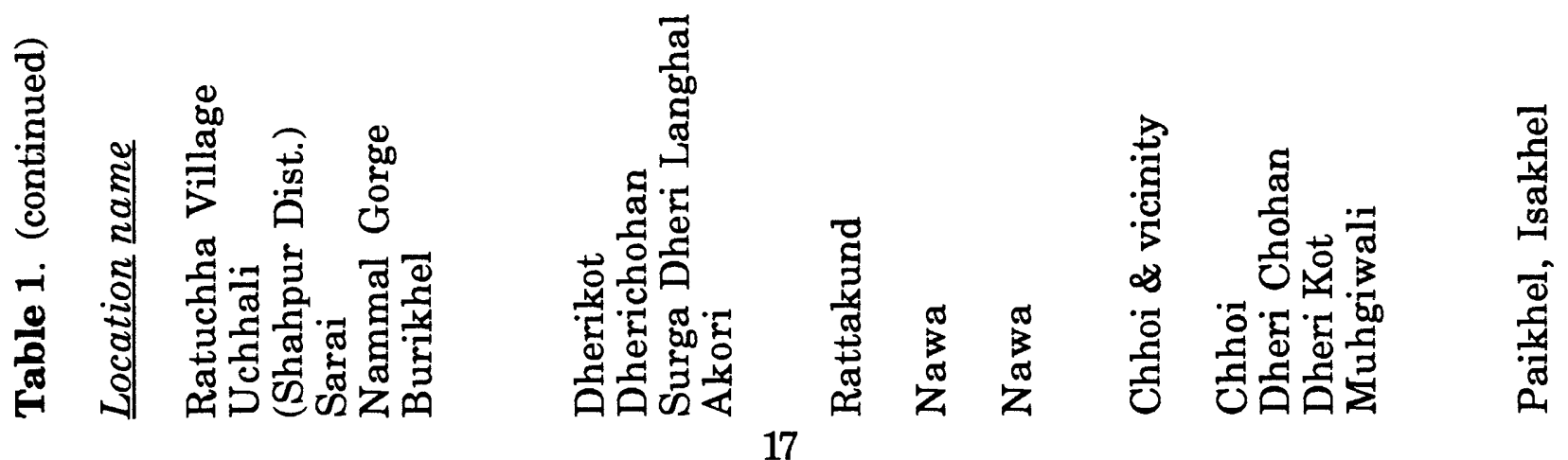


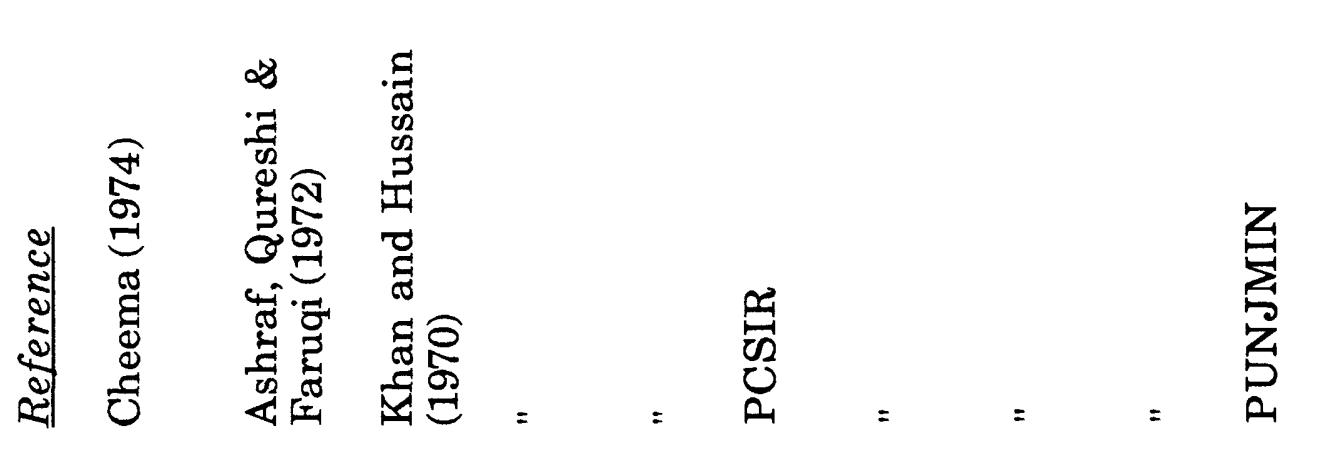

सें।

\&

ఫ

员

要

要

당

웡

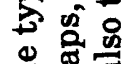

ఫ

8

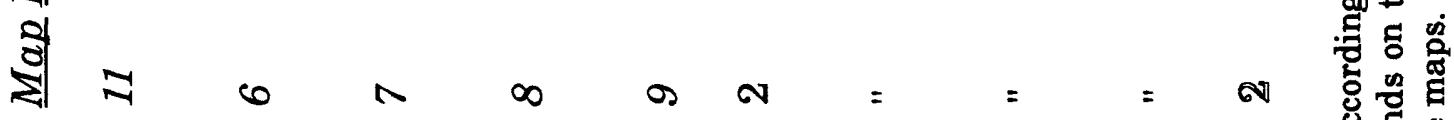

\%

:

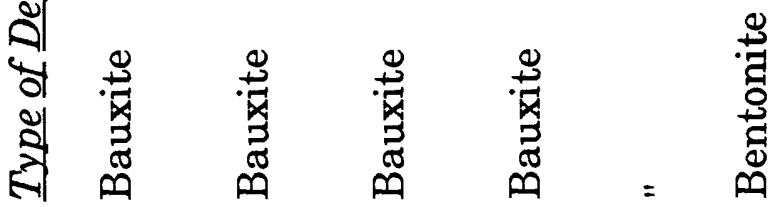

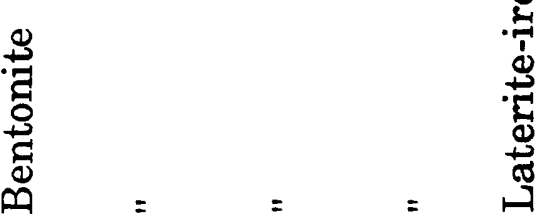

$\Phi$

a :

․ㅗㅇ $11 \frac{2}{6}$

政

ป 잉

10 $\frac{10}{4}$

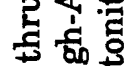

$\rightarrow$ है

क

要

江

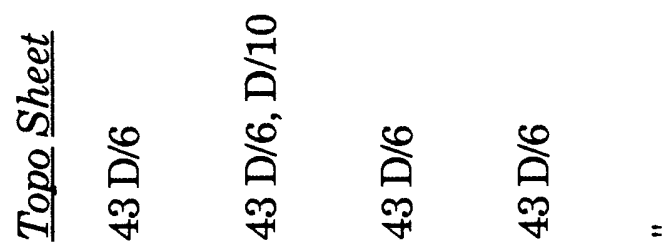

$\Xi \approx$

잉

ब

원

5

के

。

.

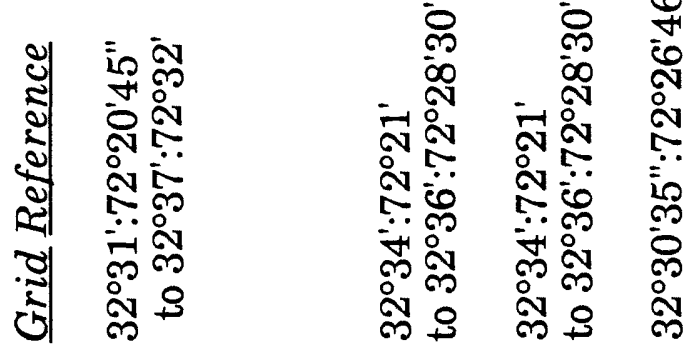

웡

ज象

원

의

워

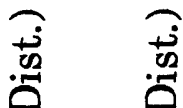

t

क

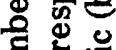

当

额

E्ट

శ్

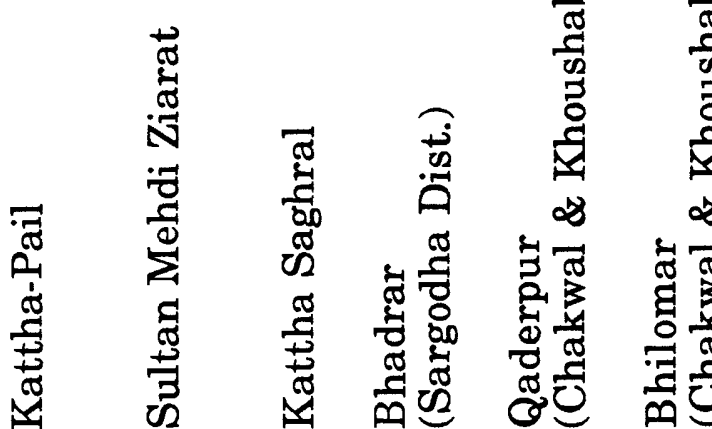

章

$\because$ 色

边

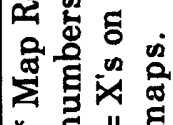




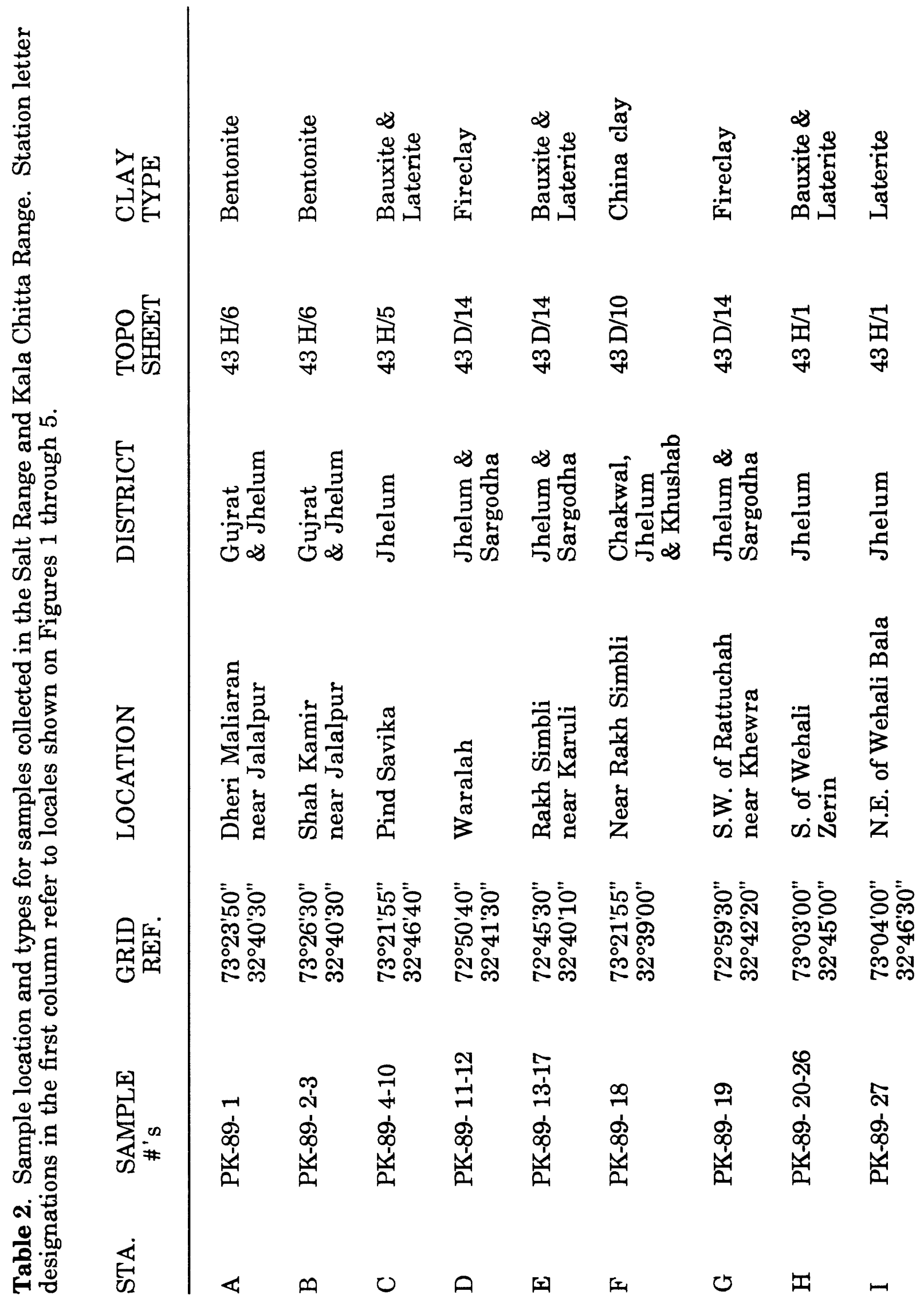




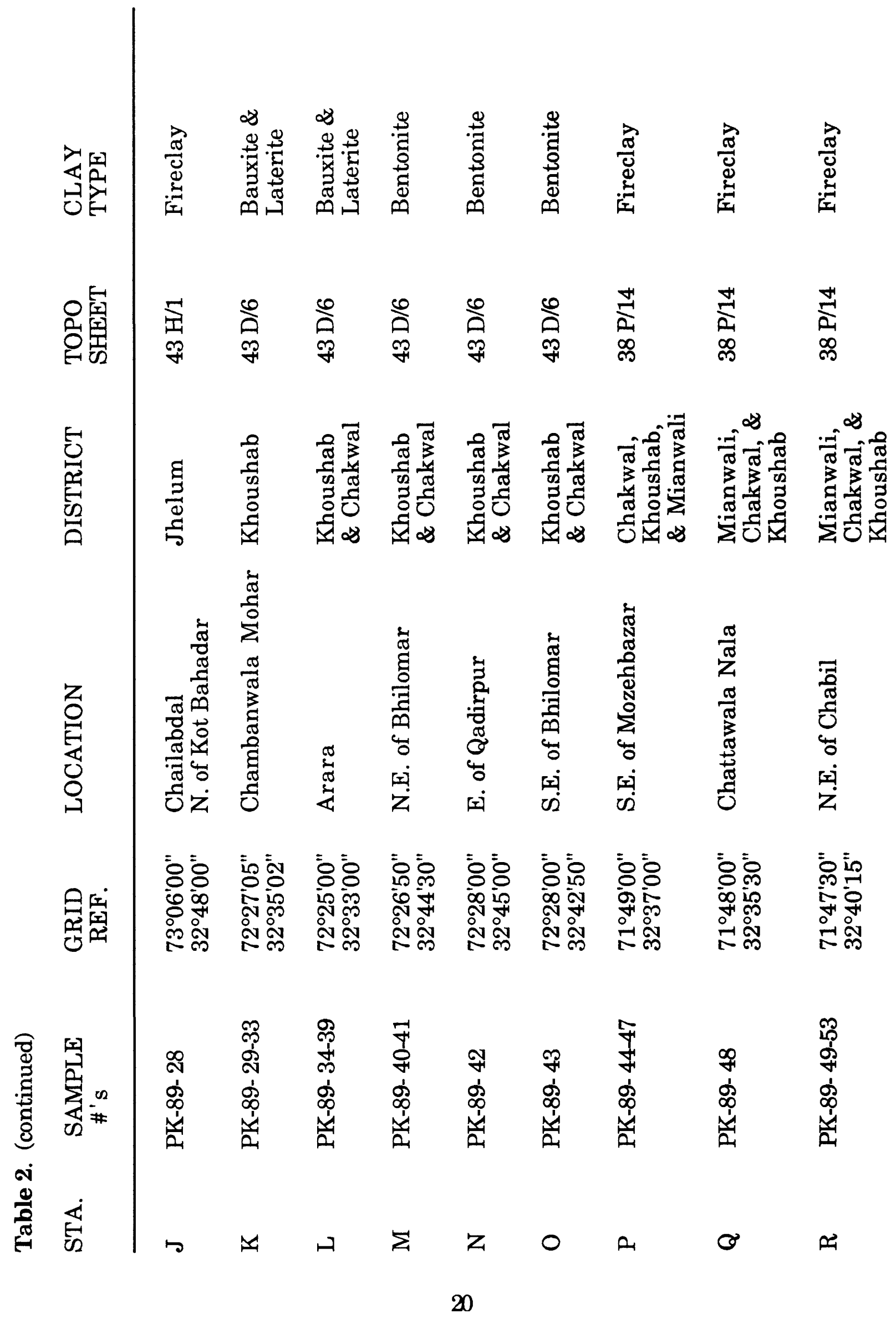




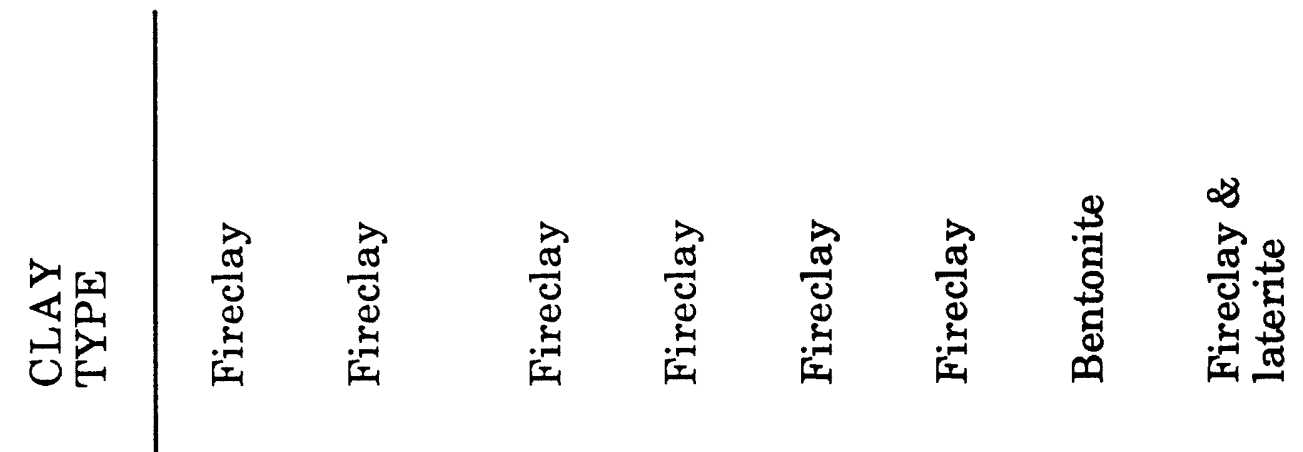

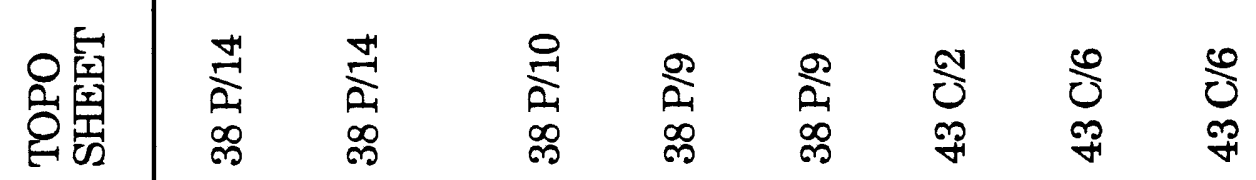

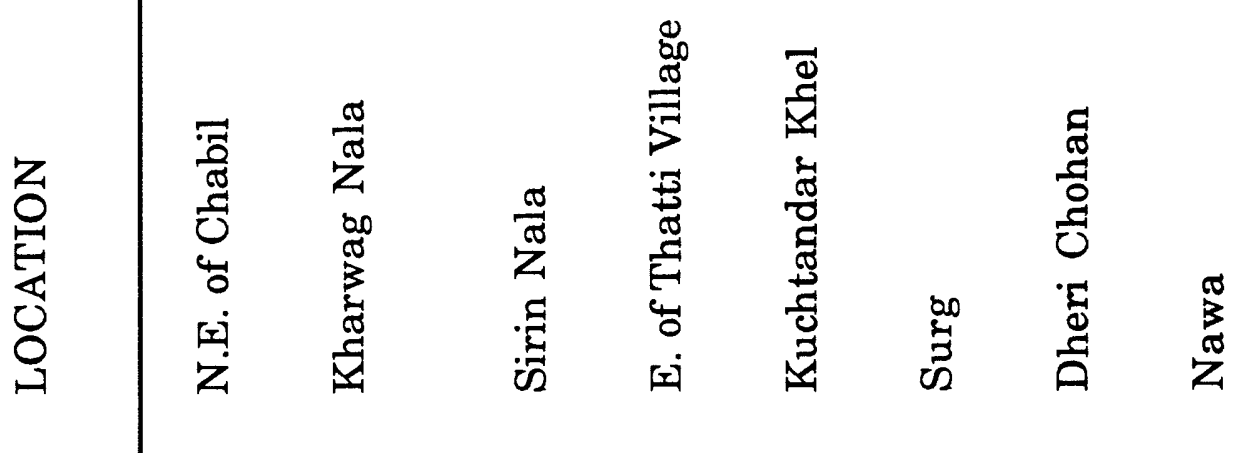

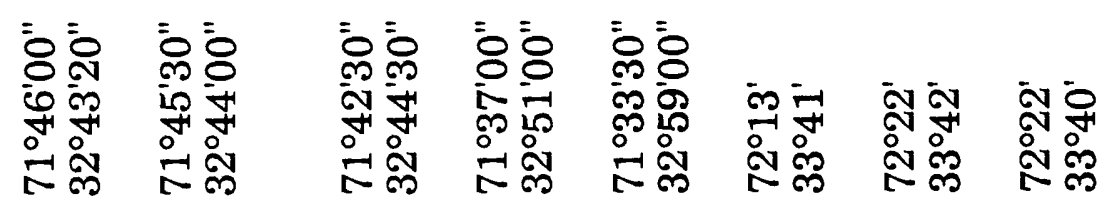

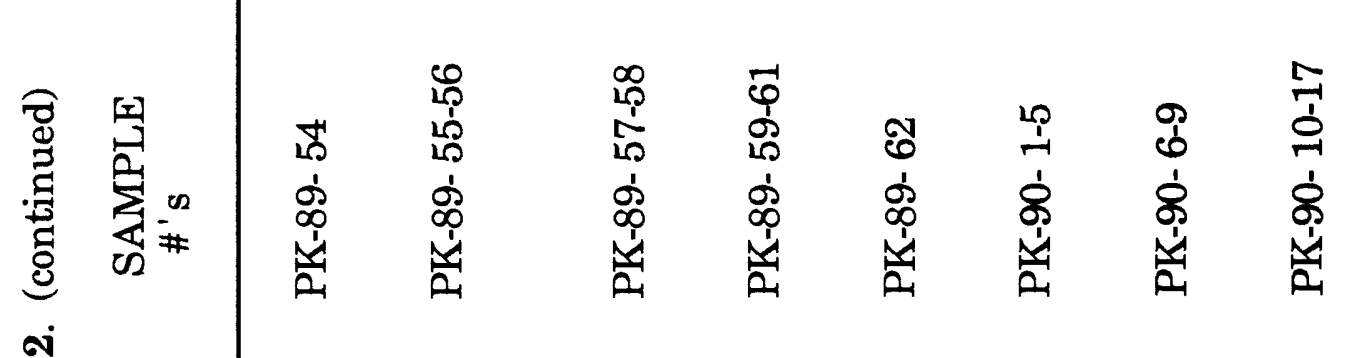

$$
\begin{aligned}
& \text { 焉 }
\end{aligned}
$$




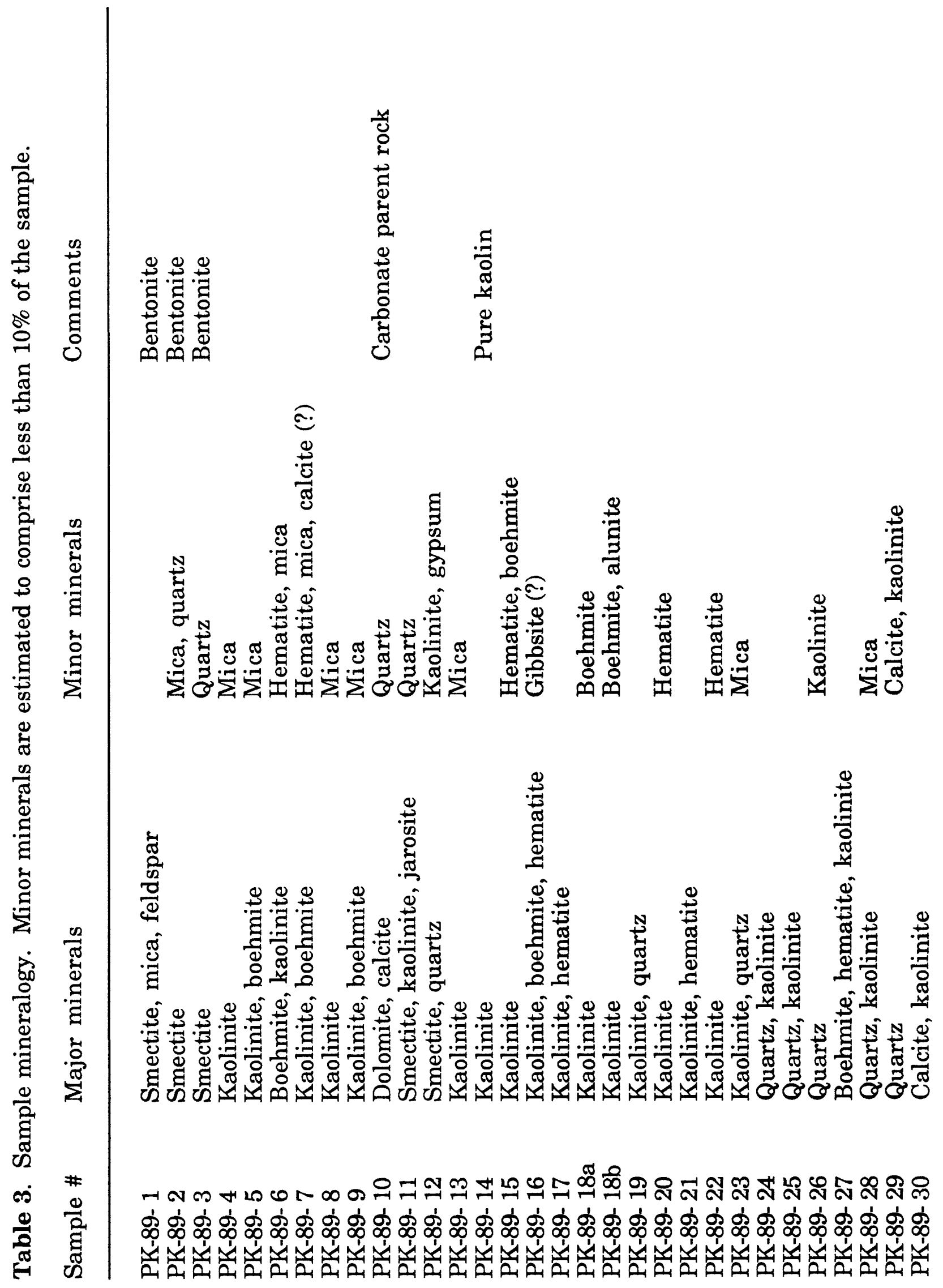




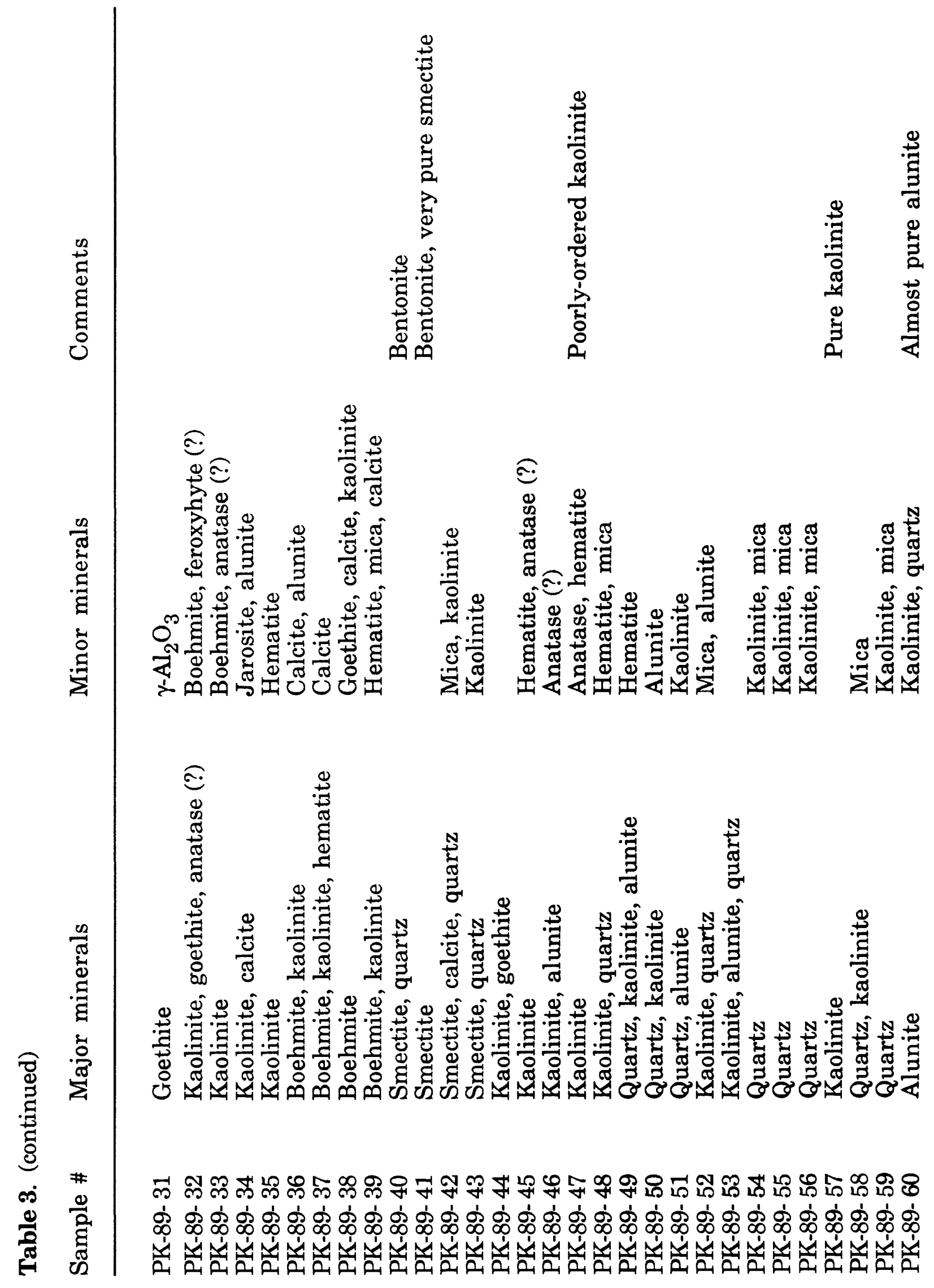




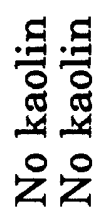

先

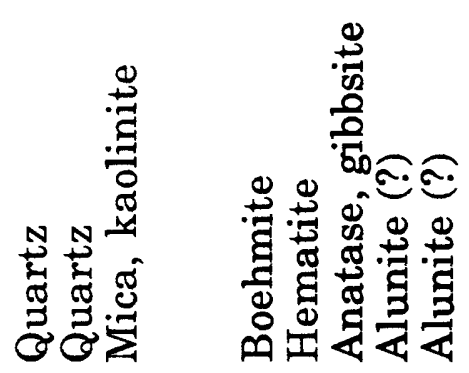

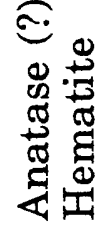

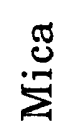

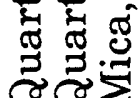

的昰文云云

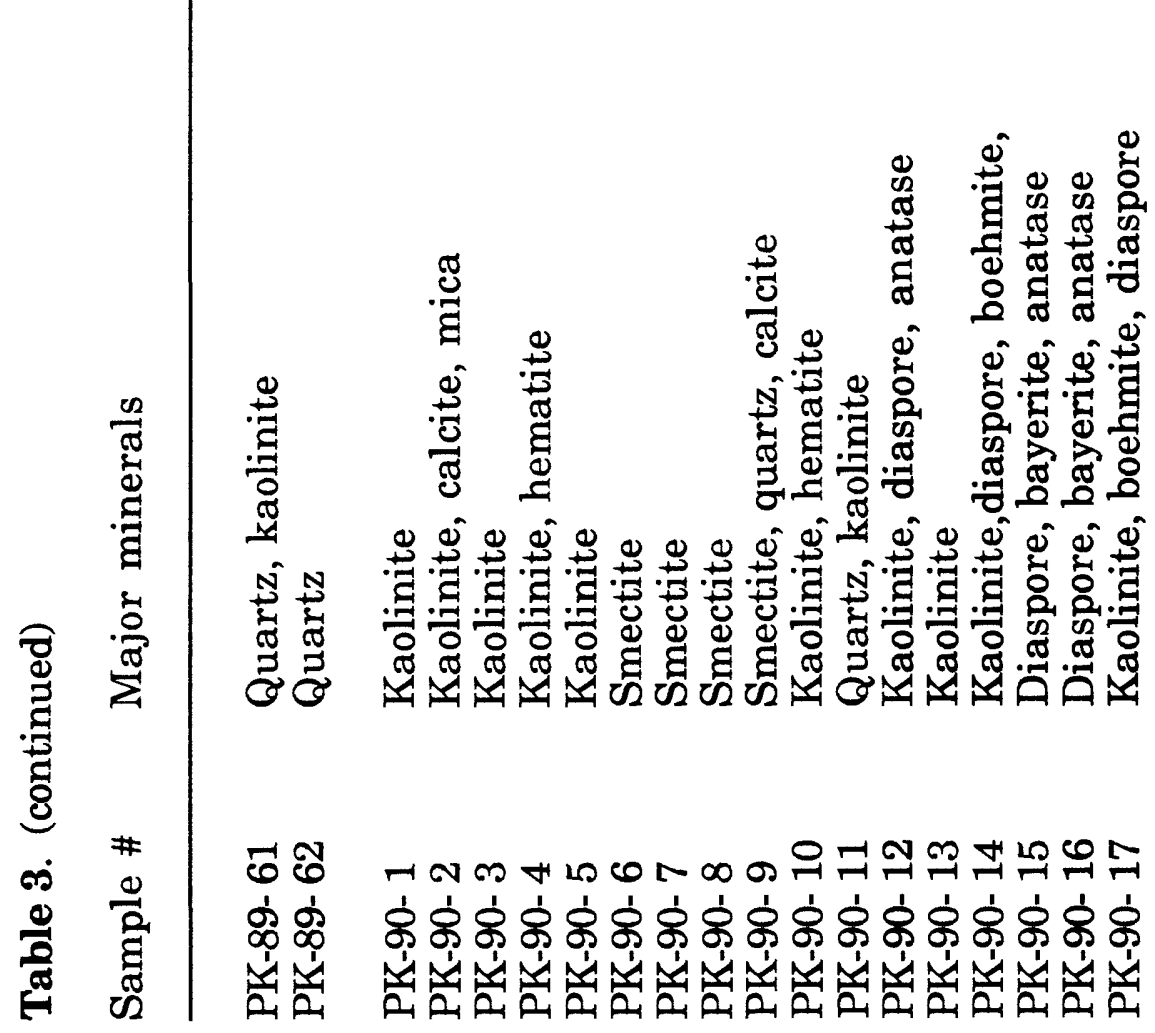




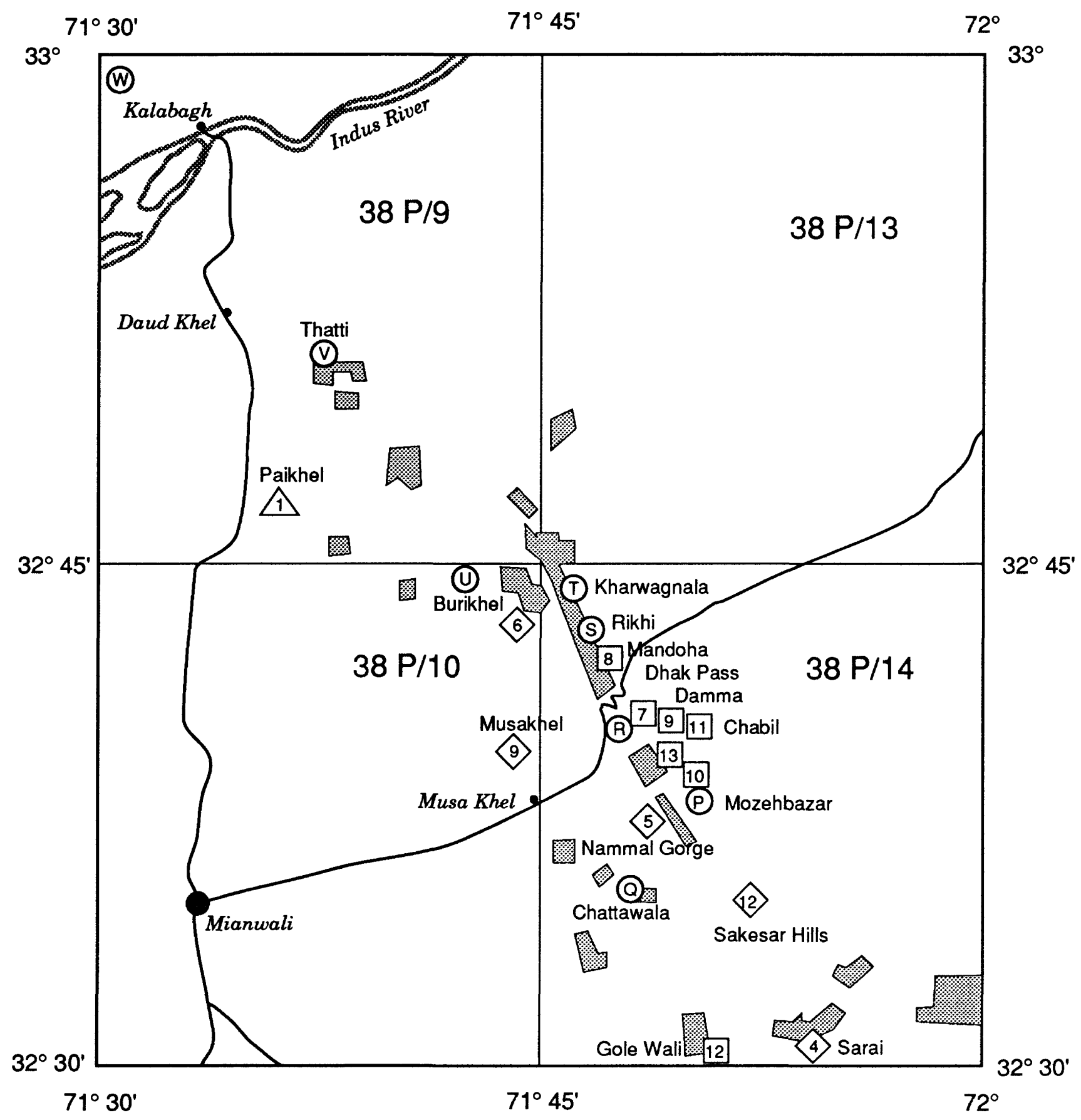

Figure 1. Sampling stations for this study (circled letters) and land leased for clay mineral deposits (courtesy of the Pakistan Directorate of Mineral Development, shaded areas), western Salt Range. Sites of previous studies are designated according to clay type:

$X_{1}$ Laterite-ironstone 今) Bauxite
(1) Bentonite \&) High-Al clay

6 Fireclay 


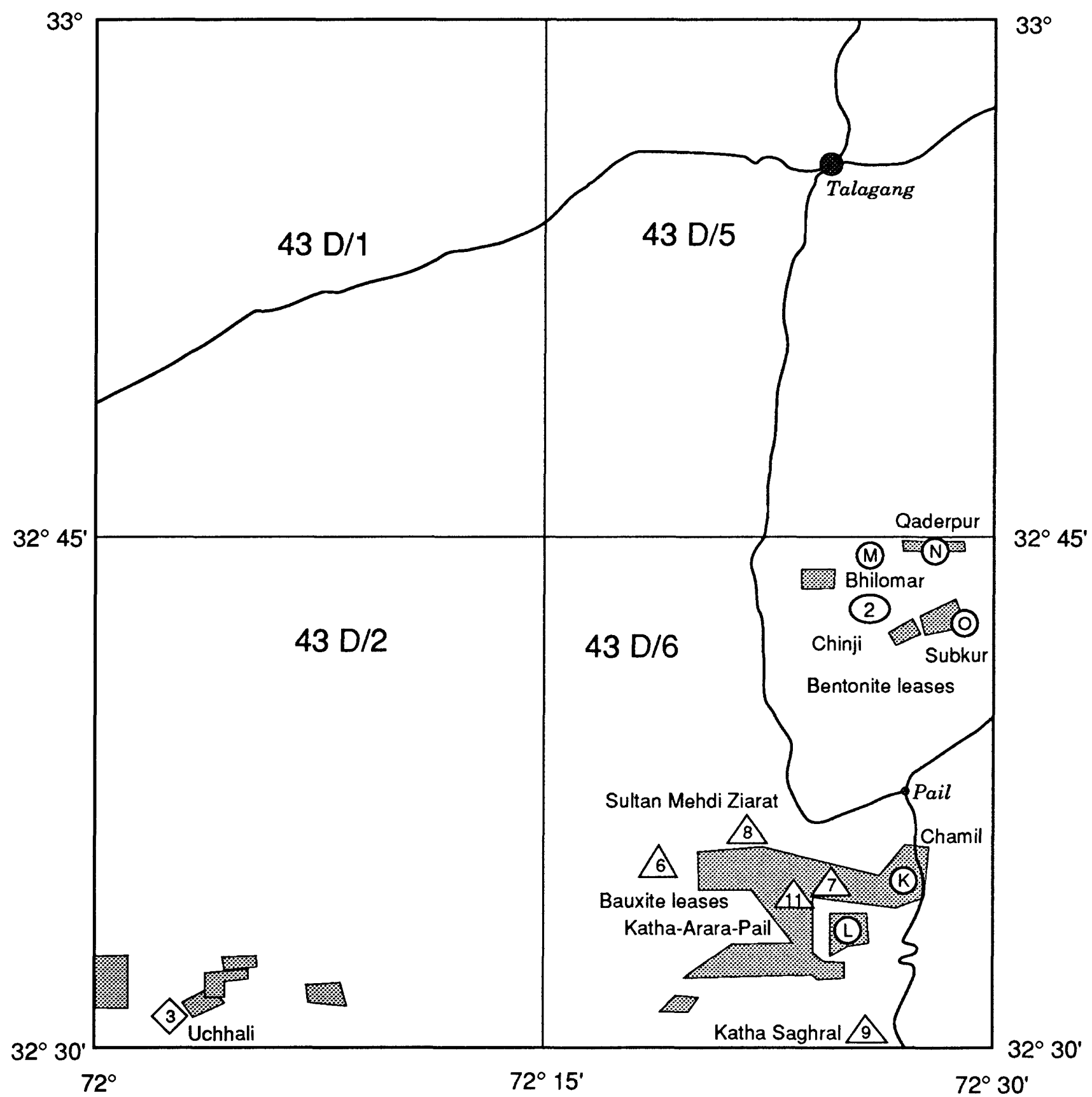

Figure 2. Sampling stations for this study (circled letters) and land leased for clay mineral deposits (courtesy of the Pakistan Directorate of Mineral Development, shaded areas), west central Salt Range. Sites of previous studies are designated according to clay type:

$X_{1}$ Laterite-ironstone

(3) Bauxite
(1) Bentonite

6 Fireclay 


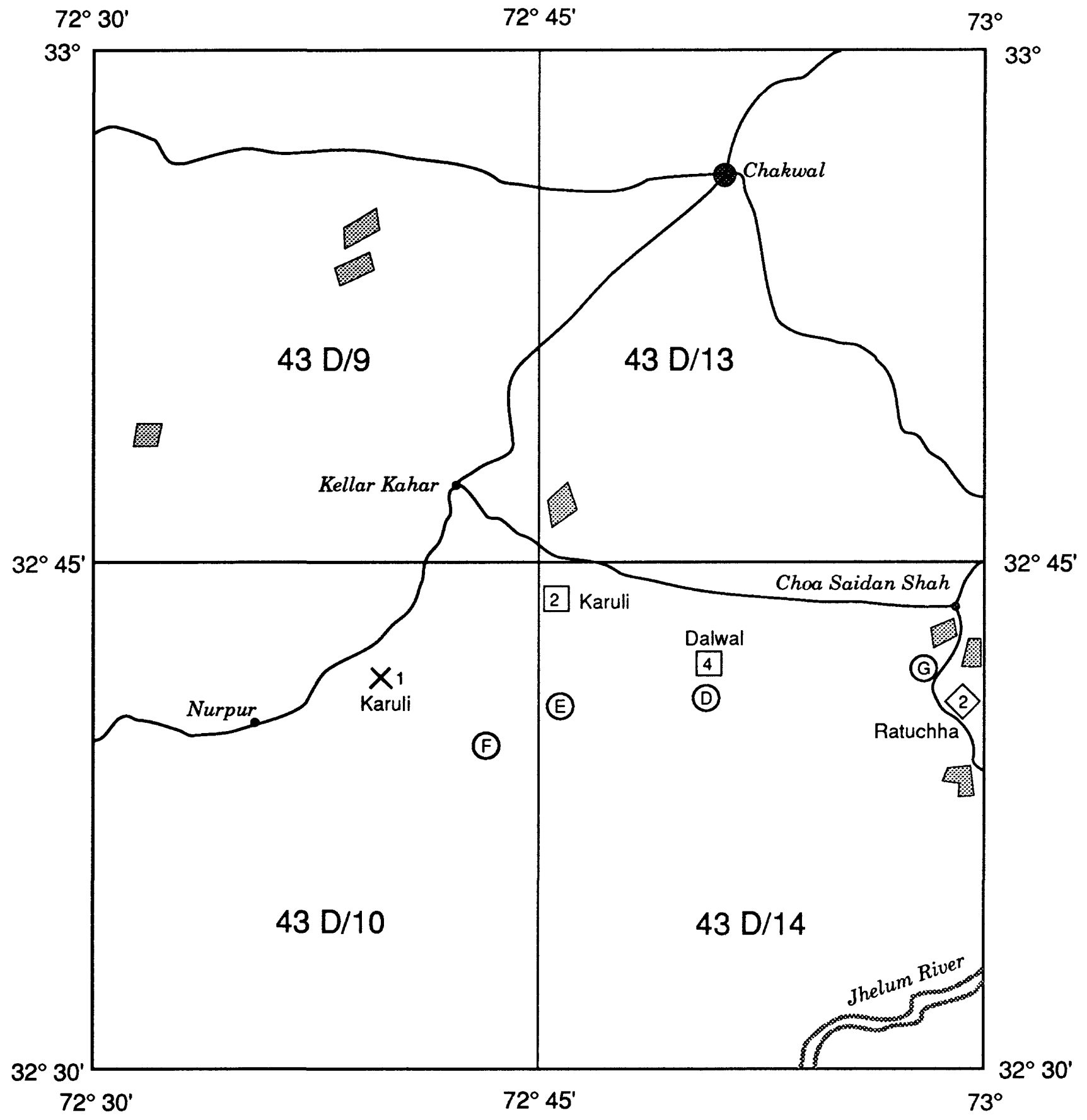

Figure 3. Sampling stations for this study (circled letters) and land leased for clay mineral deposits (courtesy of the Pakistan Directorate of Mineral Development, shaded areas), east central Salt Range. Sites of previous studies are designated according to clay type:

$X_{1}$ Laterite-ironstone

3. Bauxite

(1) Bentonite

8) High-Al clay

6 Fireclay 


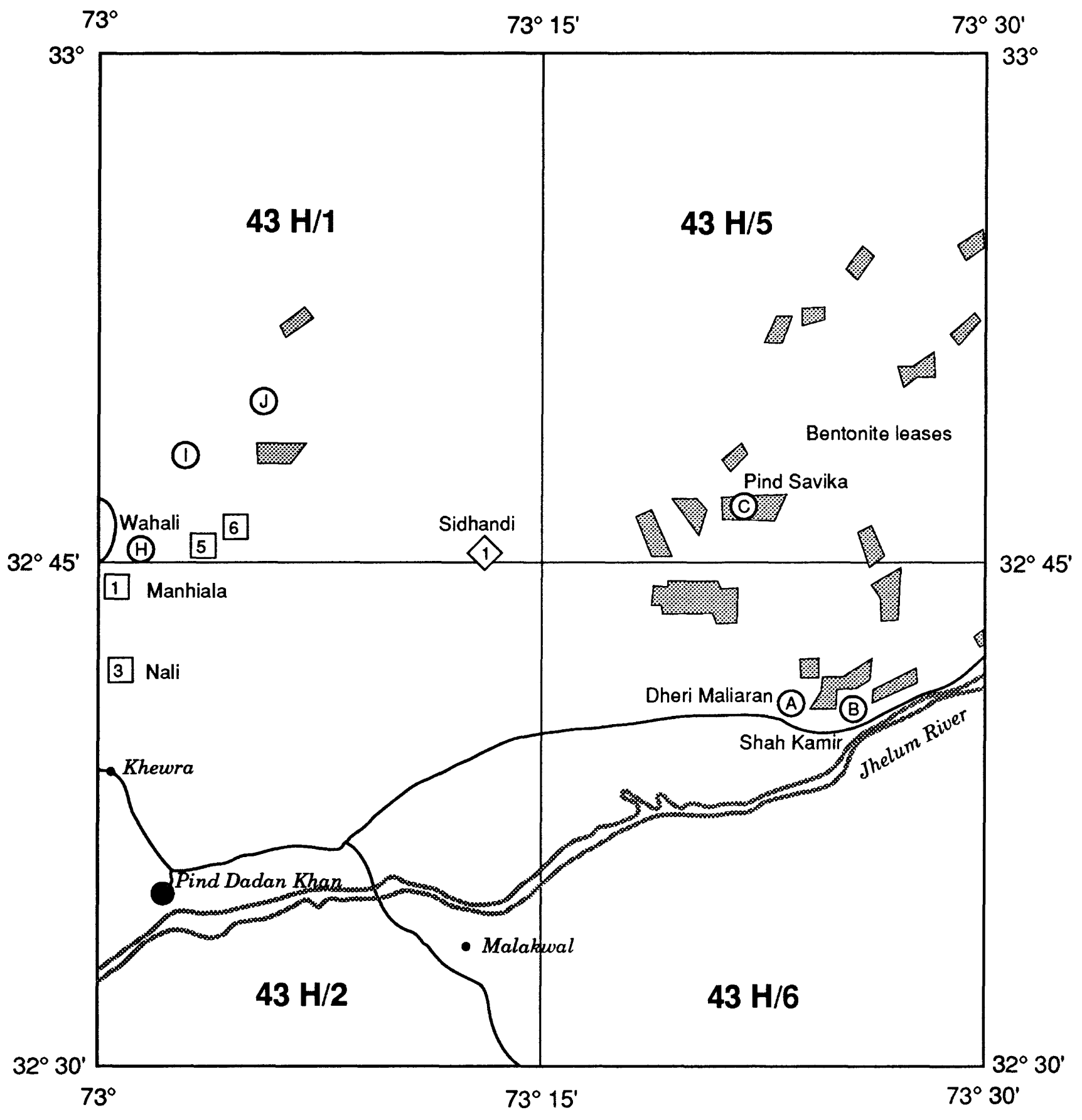

Figure 4. Sampling stations for this study (circled letters) and land leased for clay mineral deposits (courtesy of the Pakistan Directorate of Mineral Development, shaded areas), eastern Salt Range. Sites of previous studies are designated according to clay type:

$X_{1}$ Laterite-ironstone (1) Bentonite (8) High-Al clay

$$
\text { (3) Bauxite } 6 \text { Fireclay }
$$




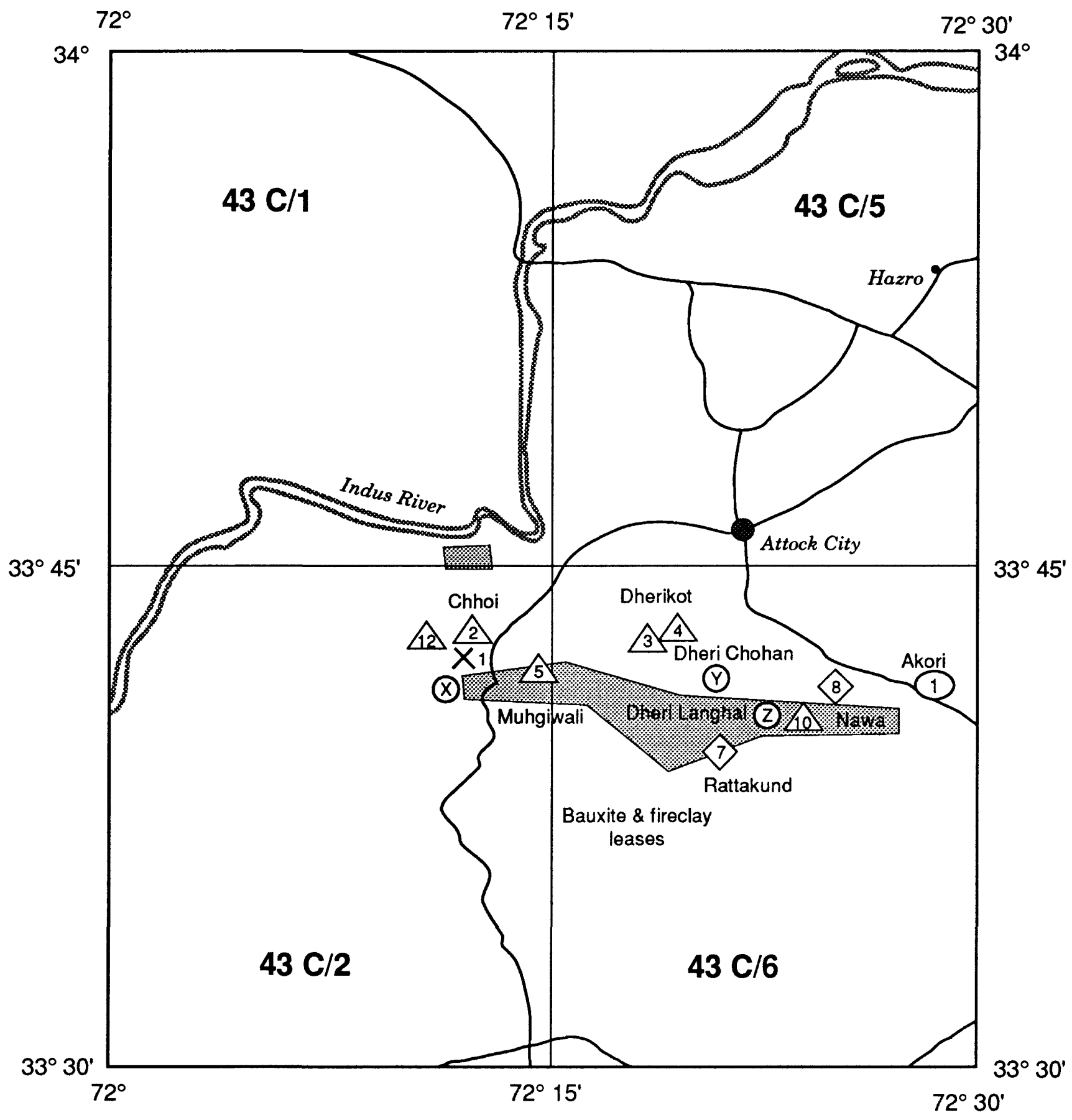

Figure 5. Sampling stations for this study (circled letters) and land leased for clay mineral deposits (courtesy of the Pakistan Directorate of Mineral Development, shaded areas), Kala Chitta Range. Sites of previous studies are designated according to clay type:

$X_{1}$ Laterite-ironstone

今. Bauxite
(1) Bentonite 8 . High-Al clay

6 Fireclay 


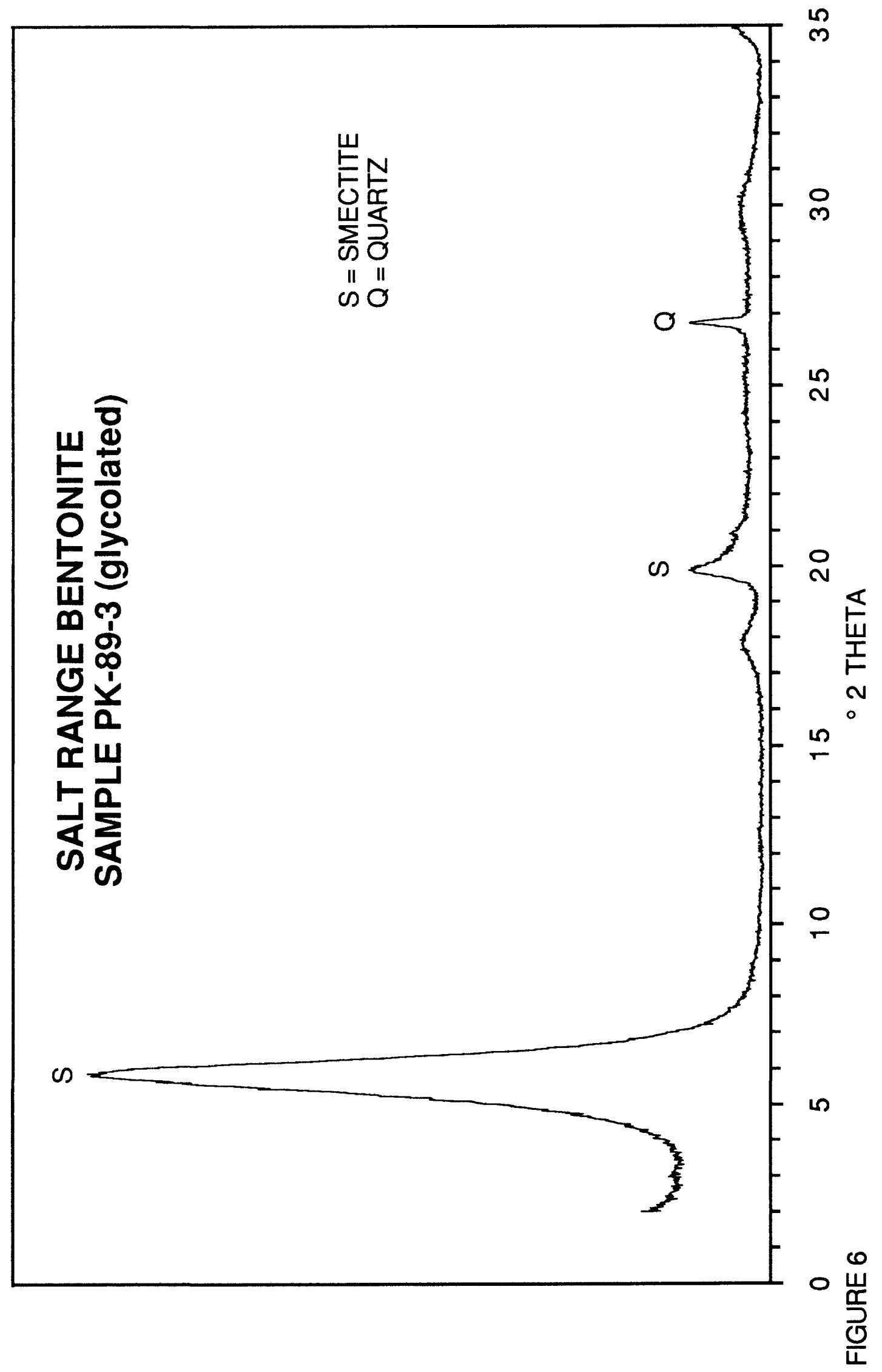




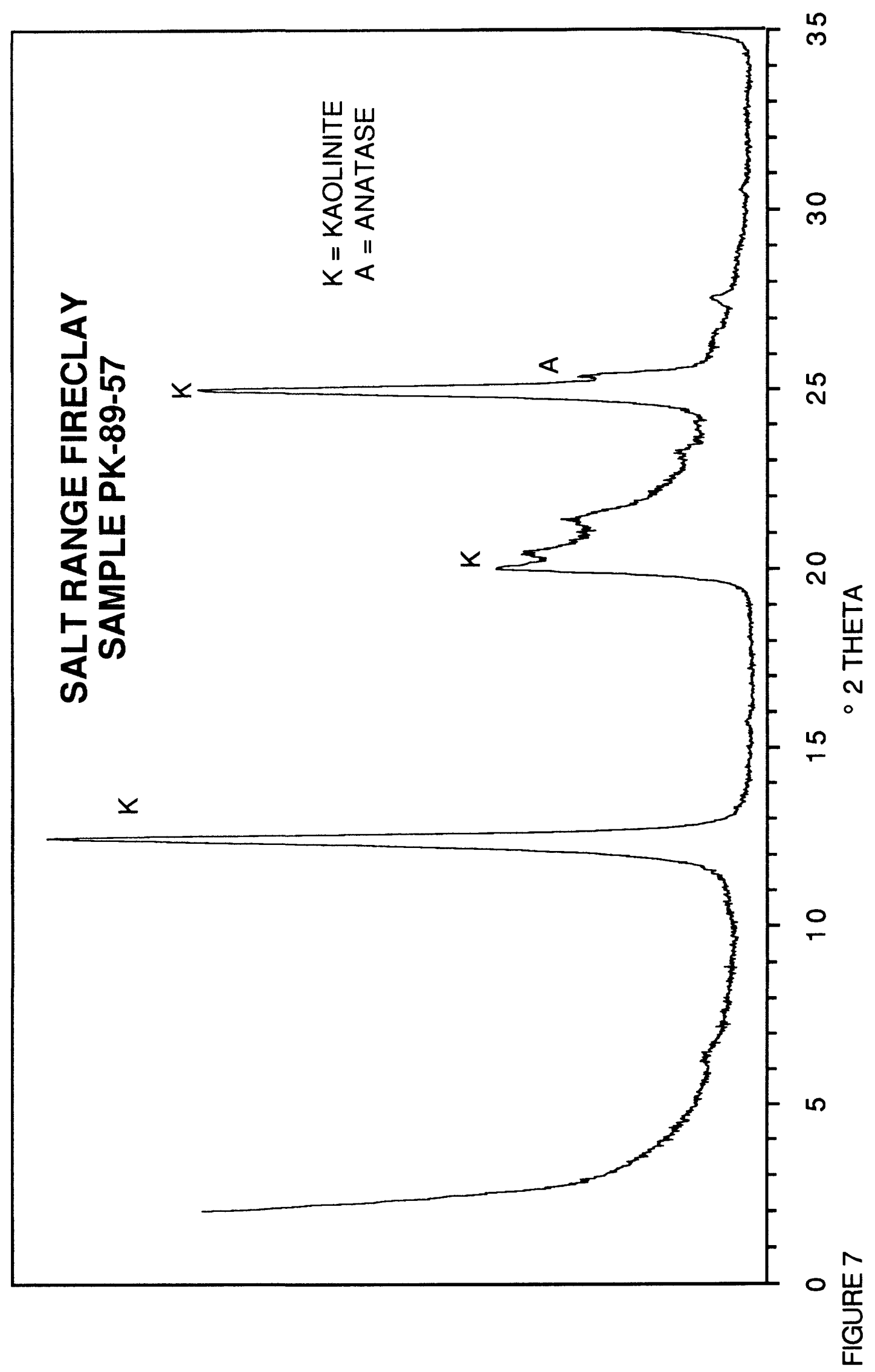




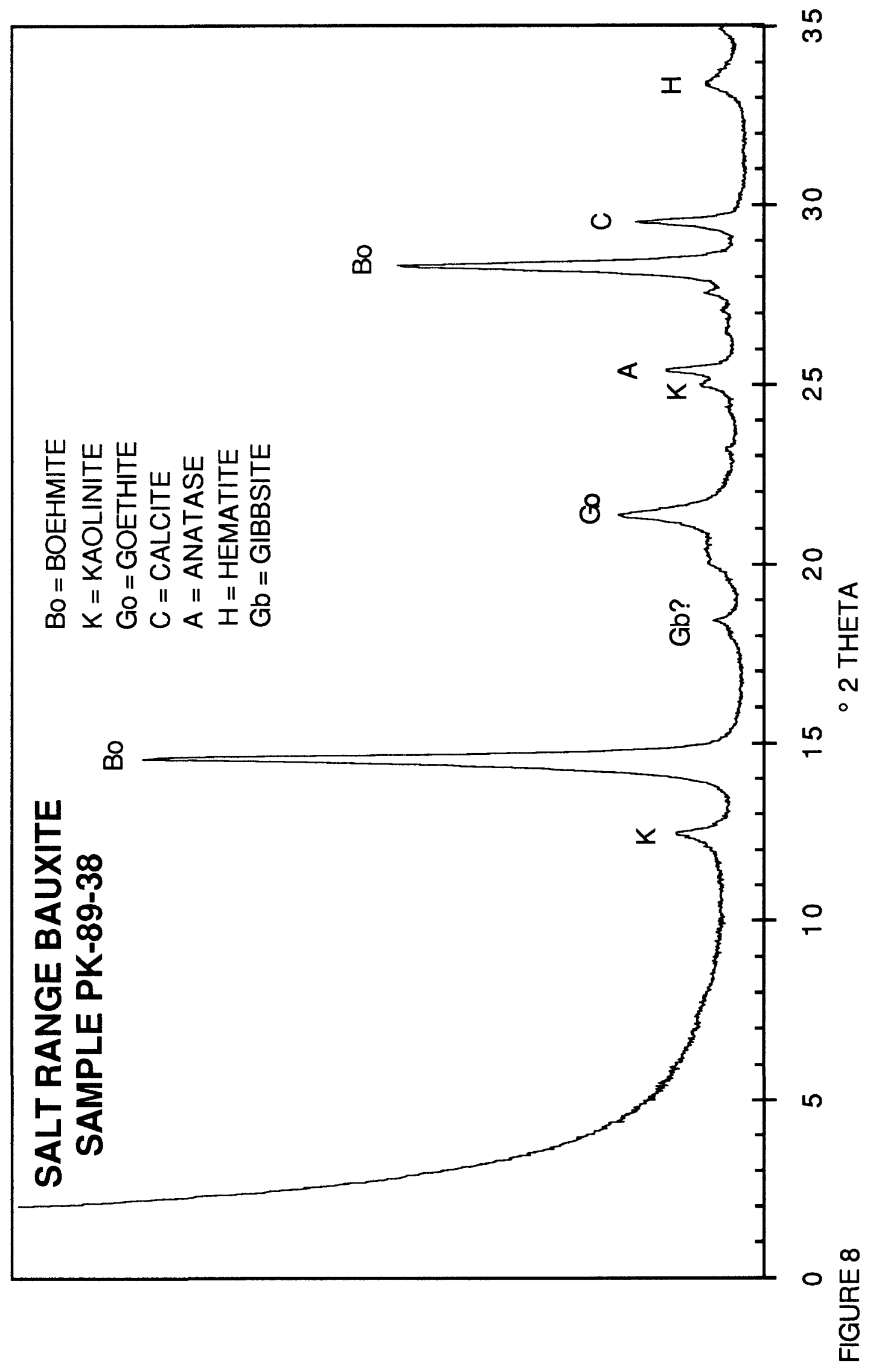




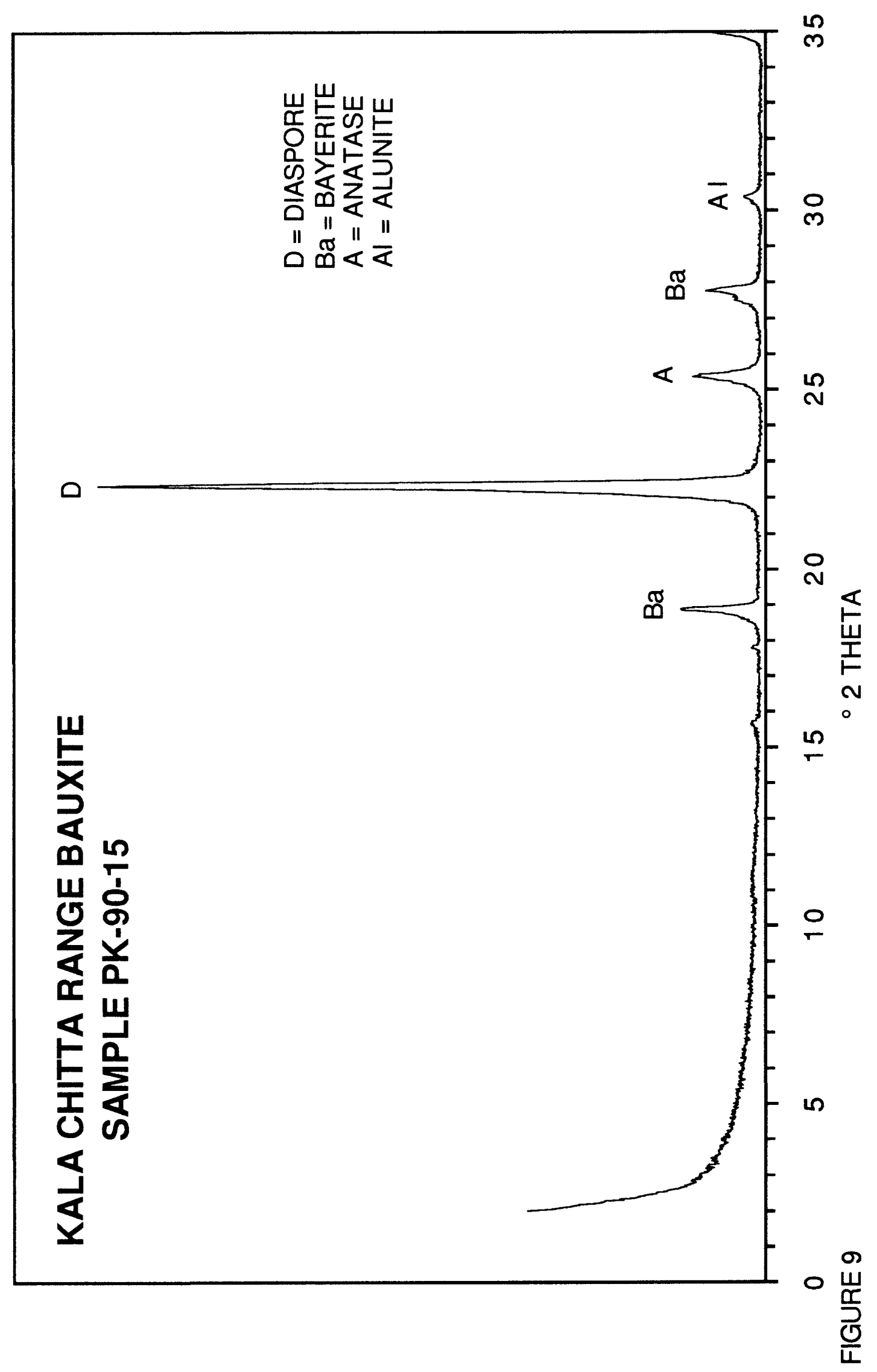


APPENDIX II: Thermogravimetric data for Pakistan clays: upper curve represents weight loss curve (in weight percent) and lower curve is the first derivative of weight loss, indicating temperature and magnitude of weight loss events. 


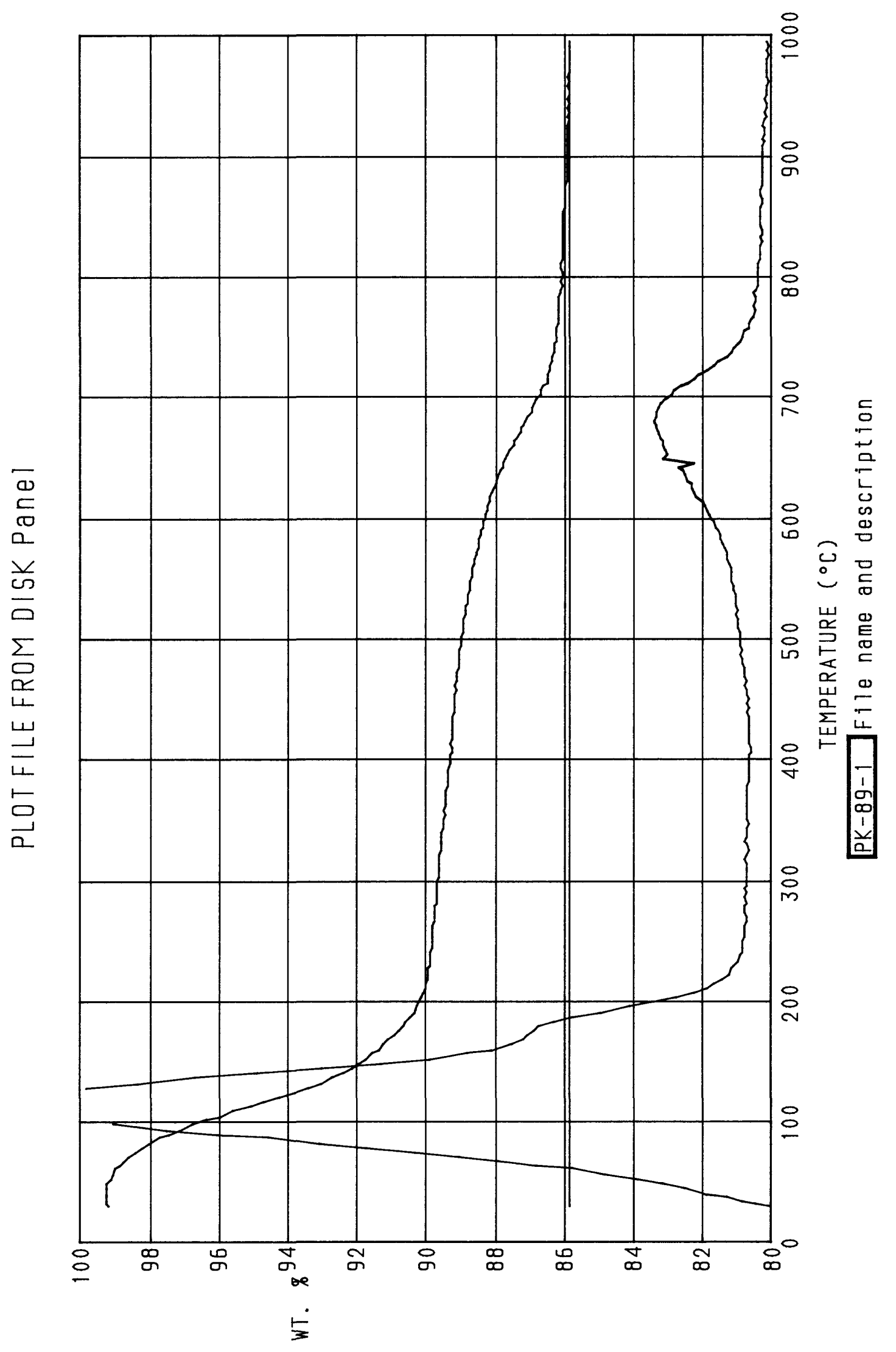




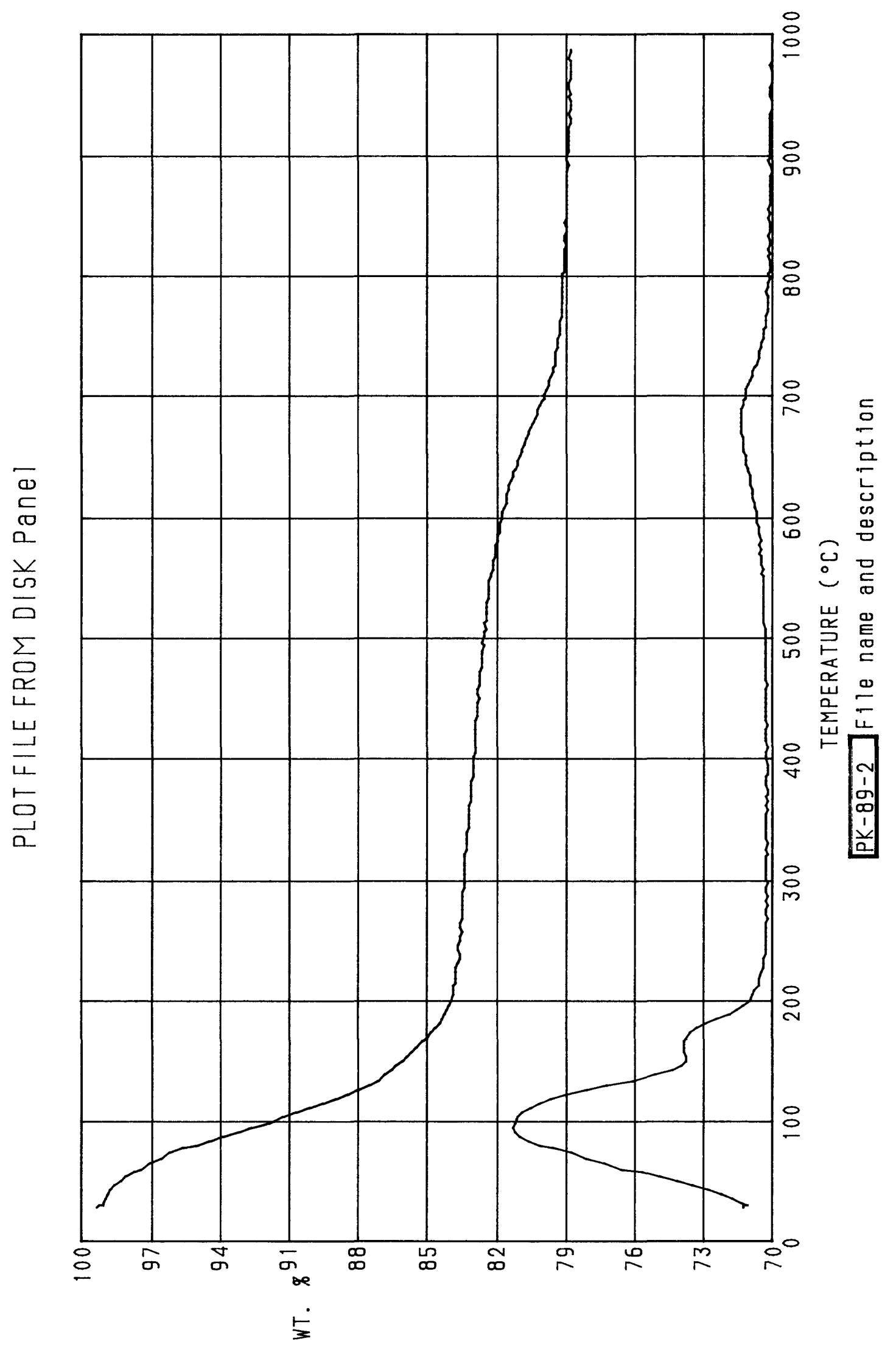




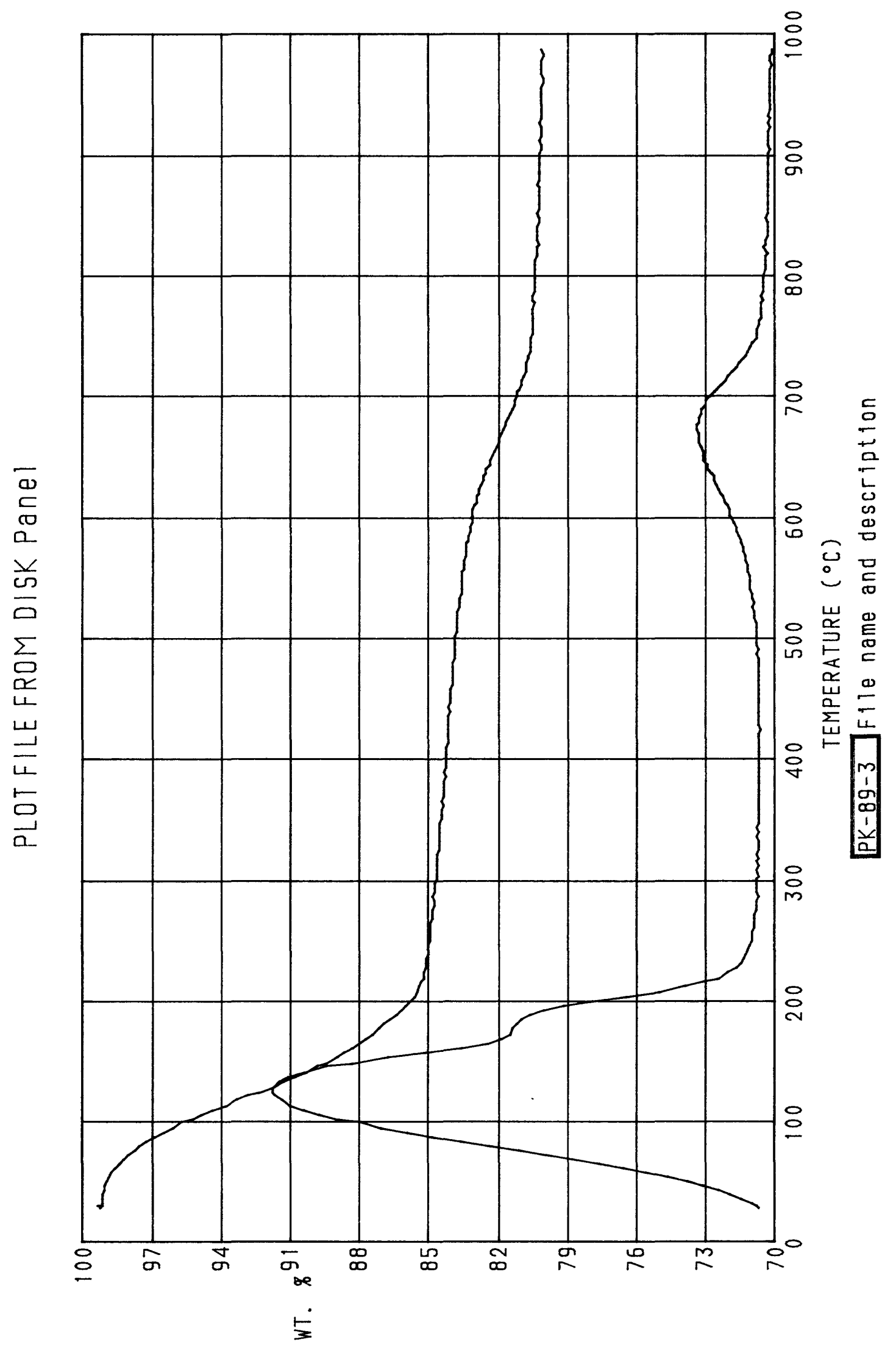




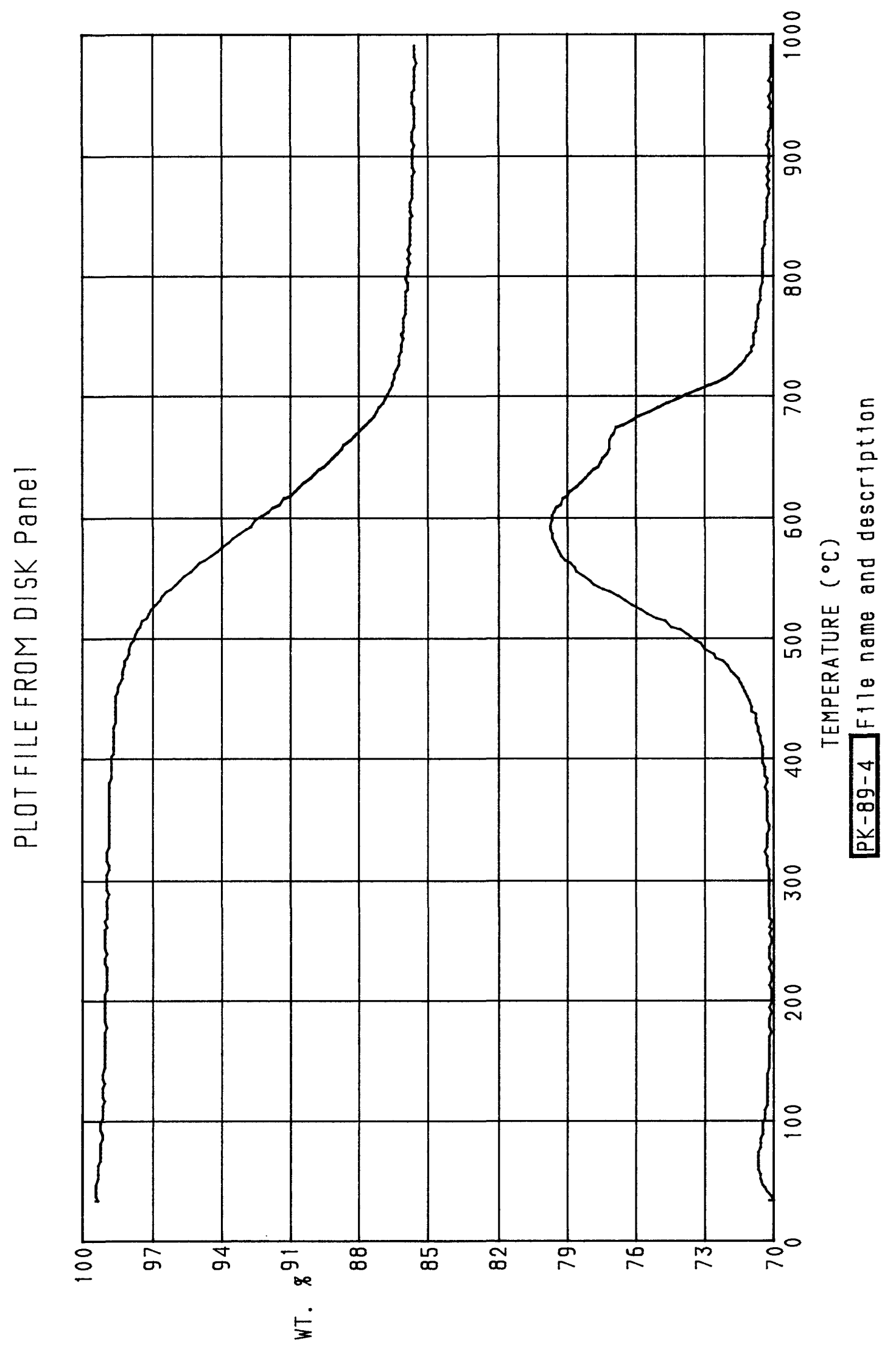




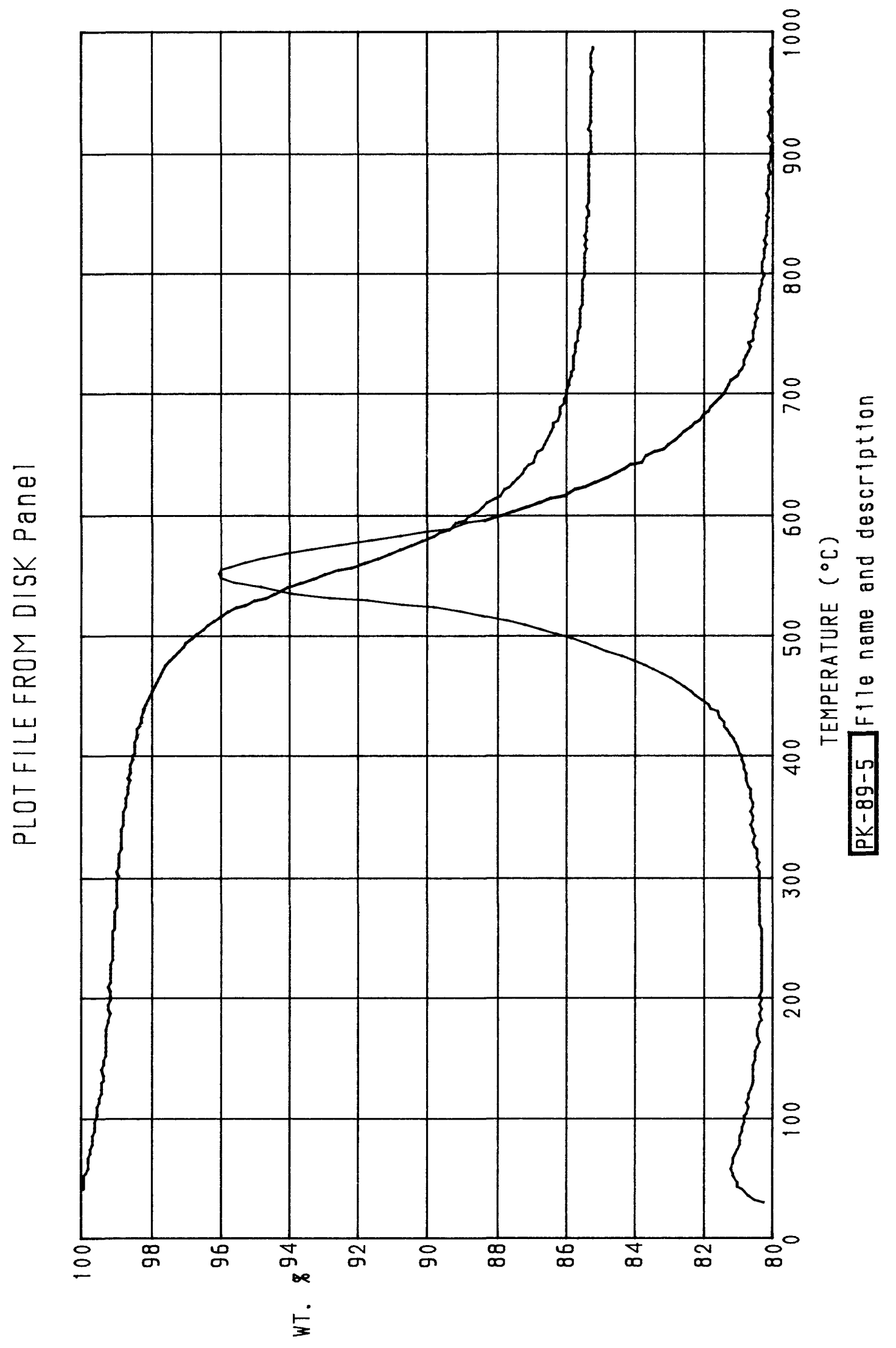




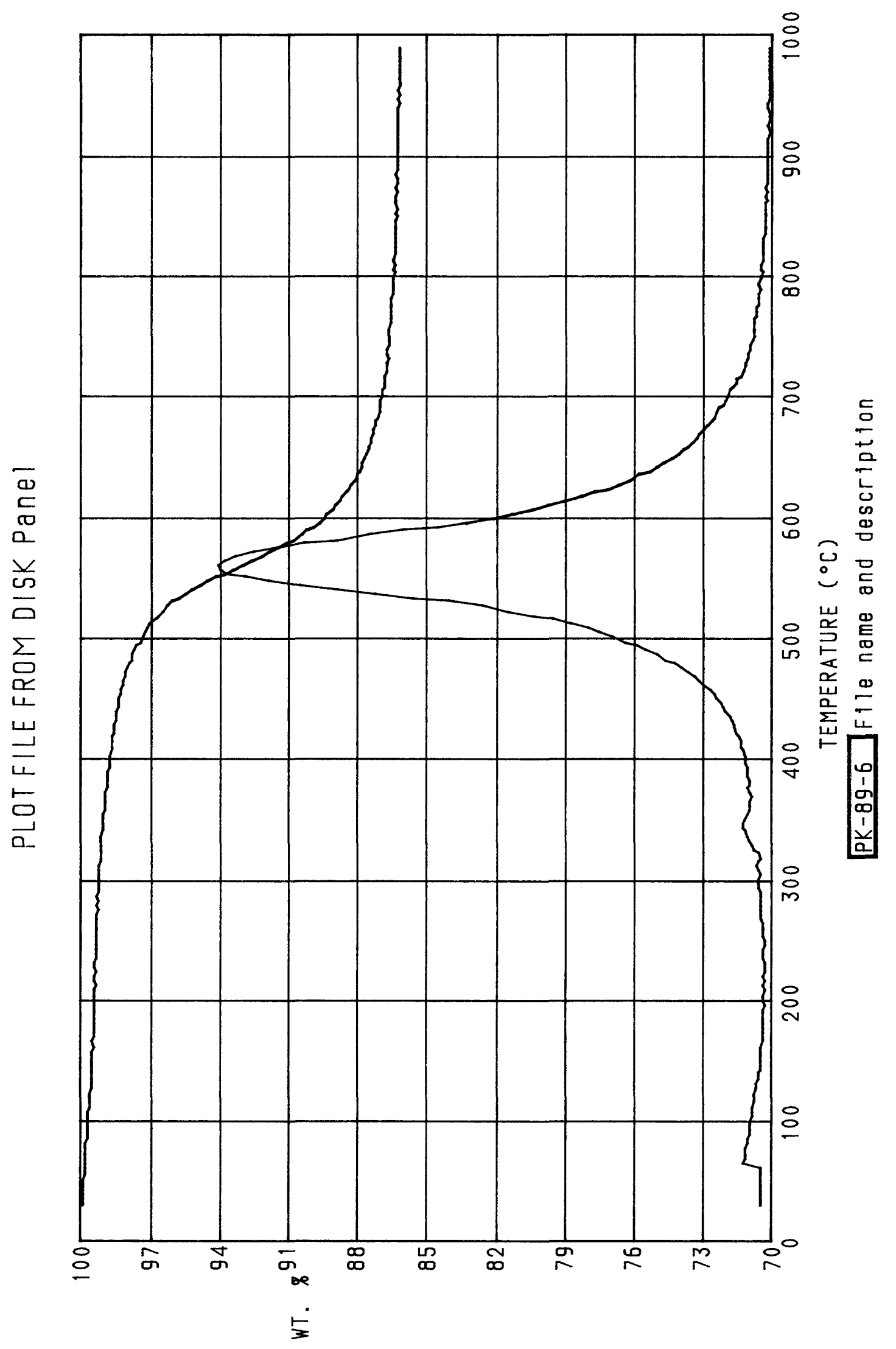




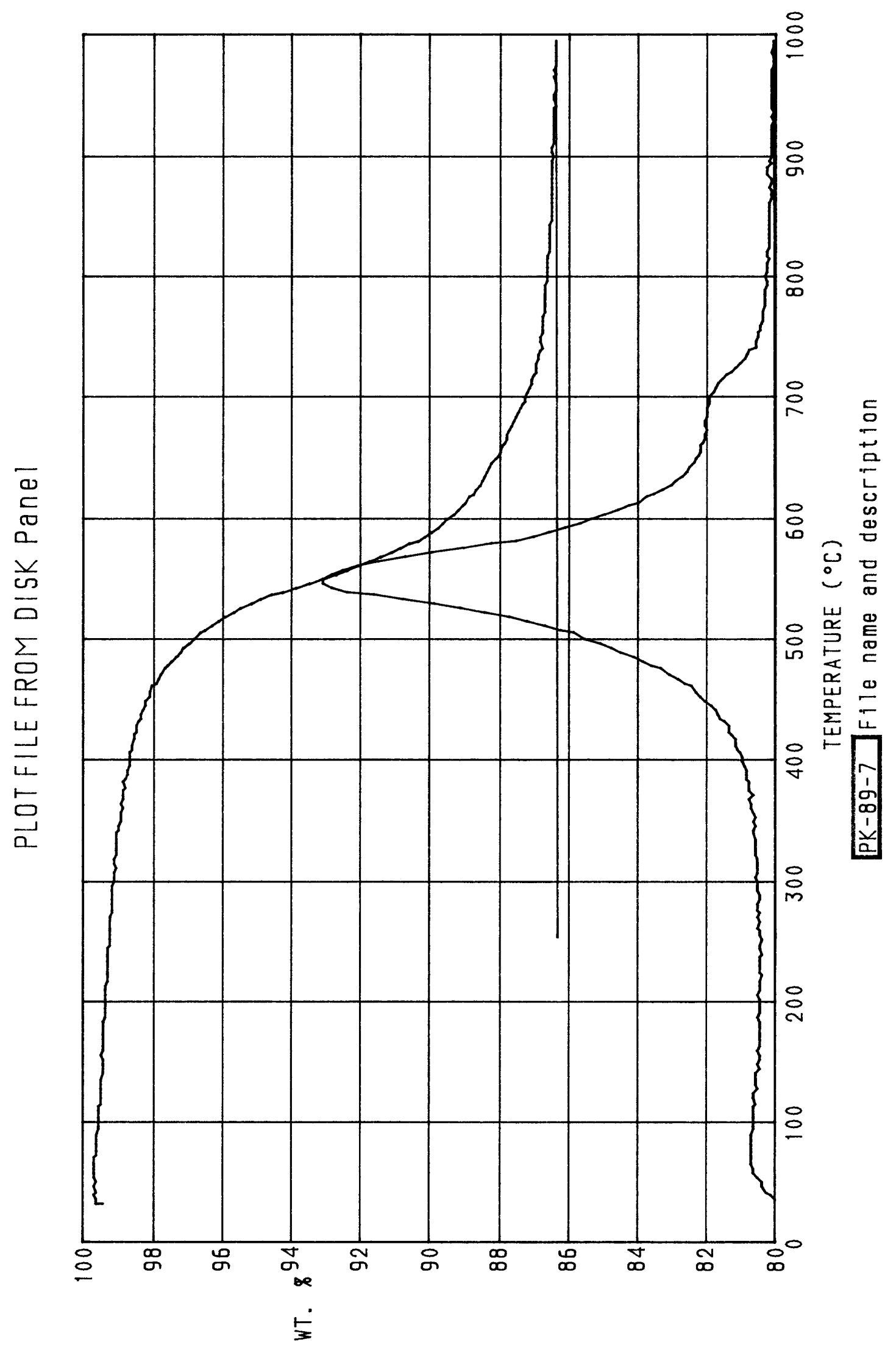




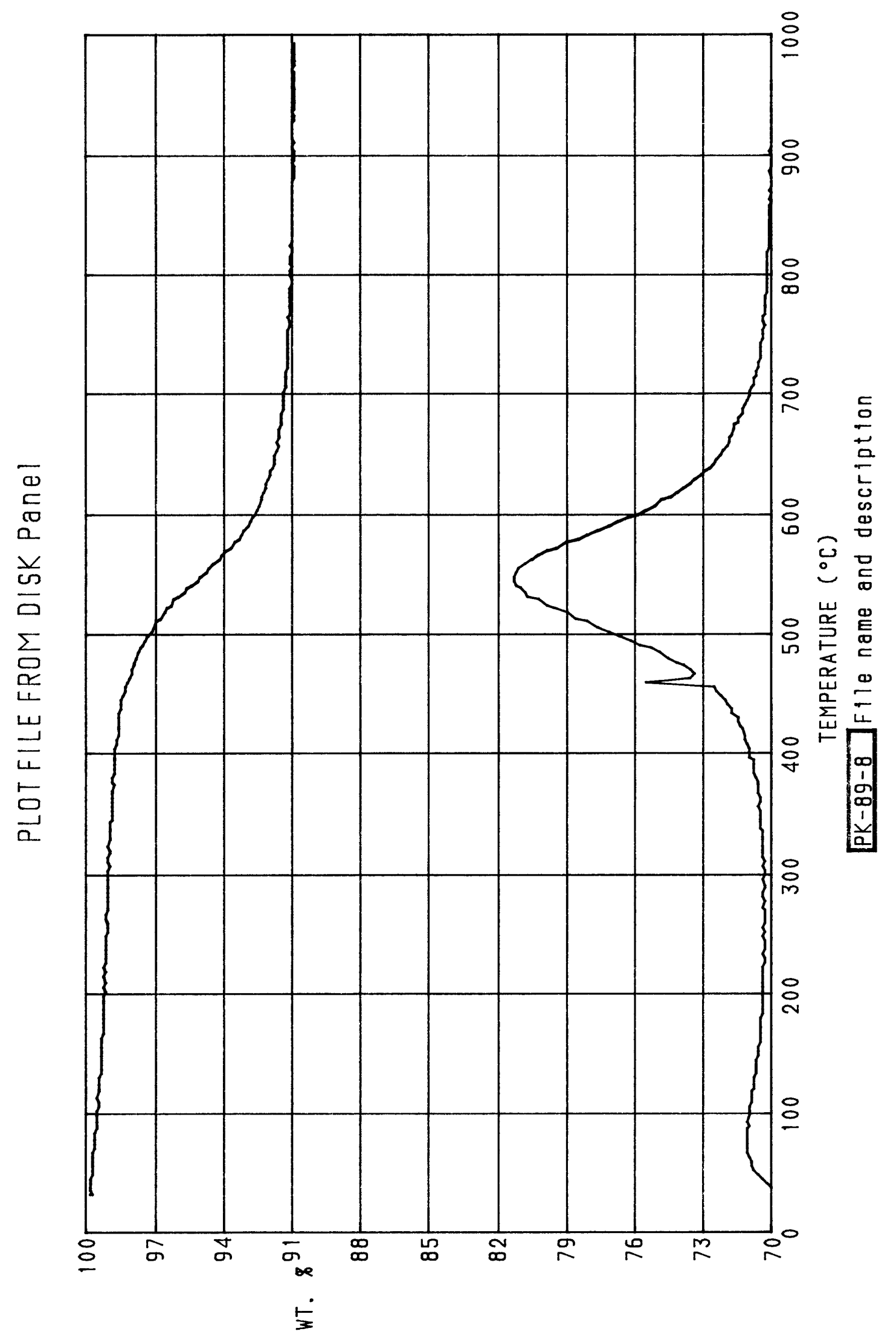




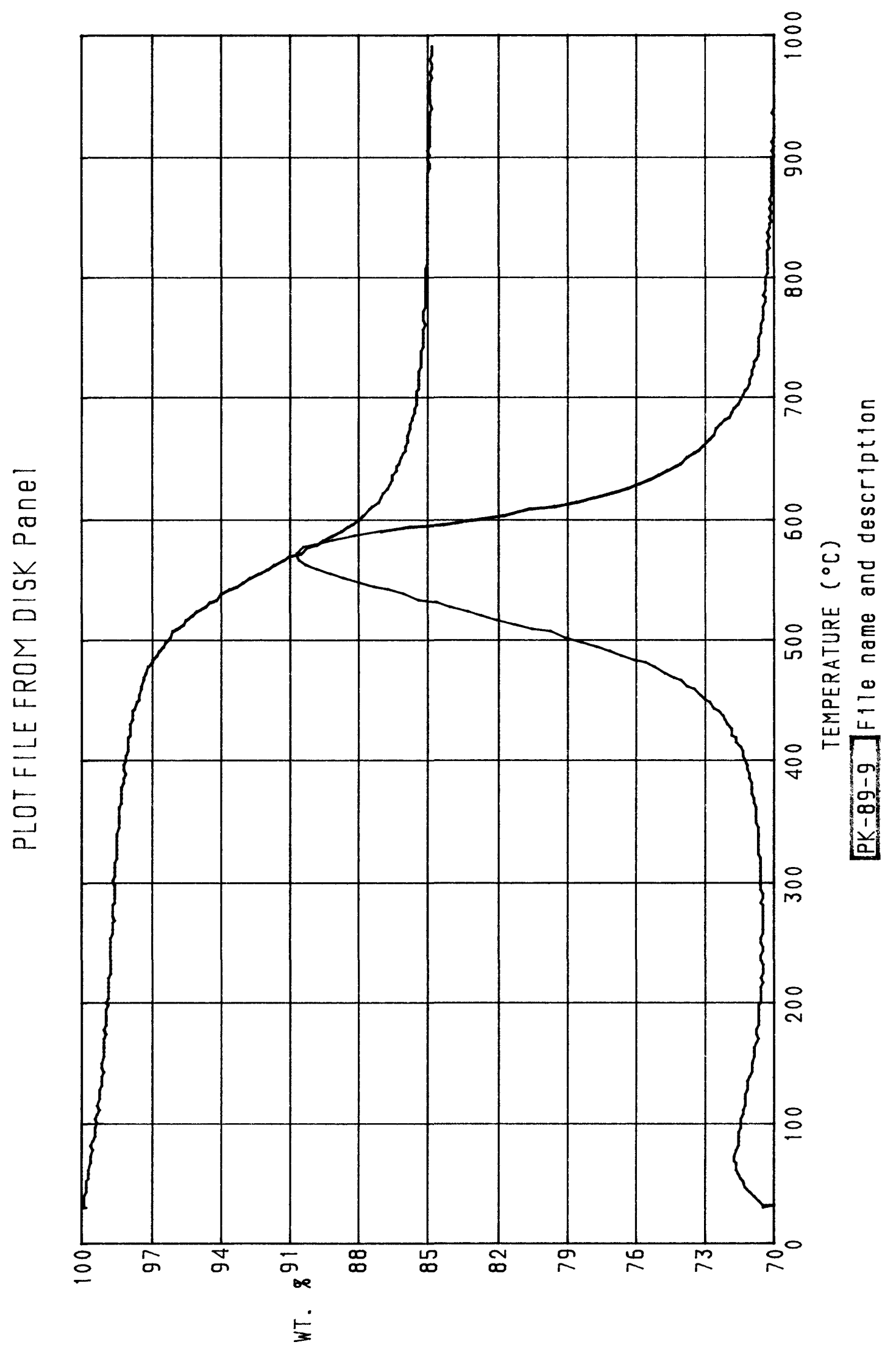




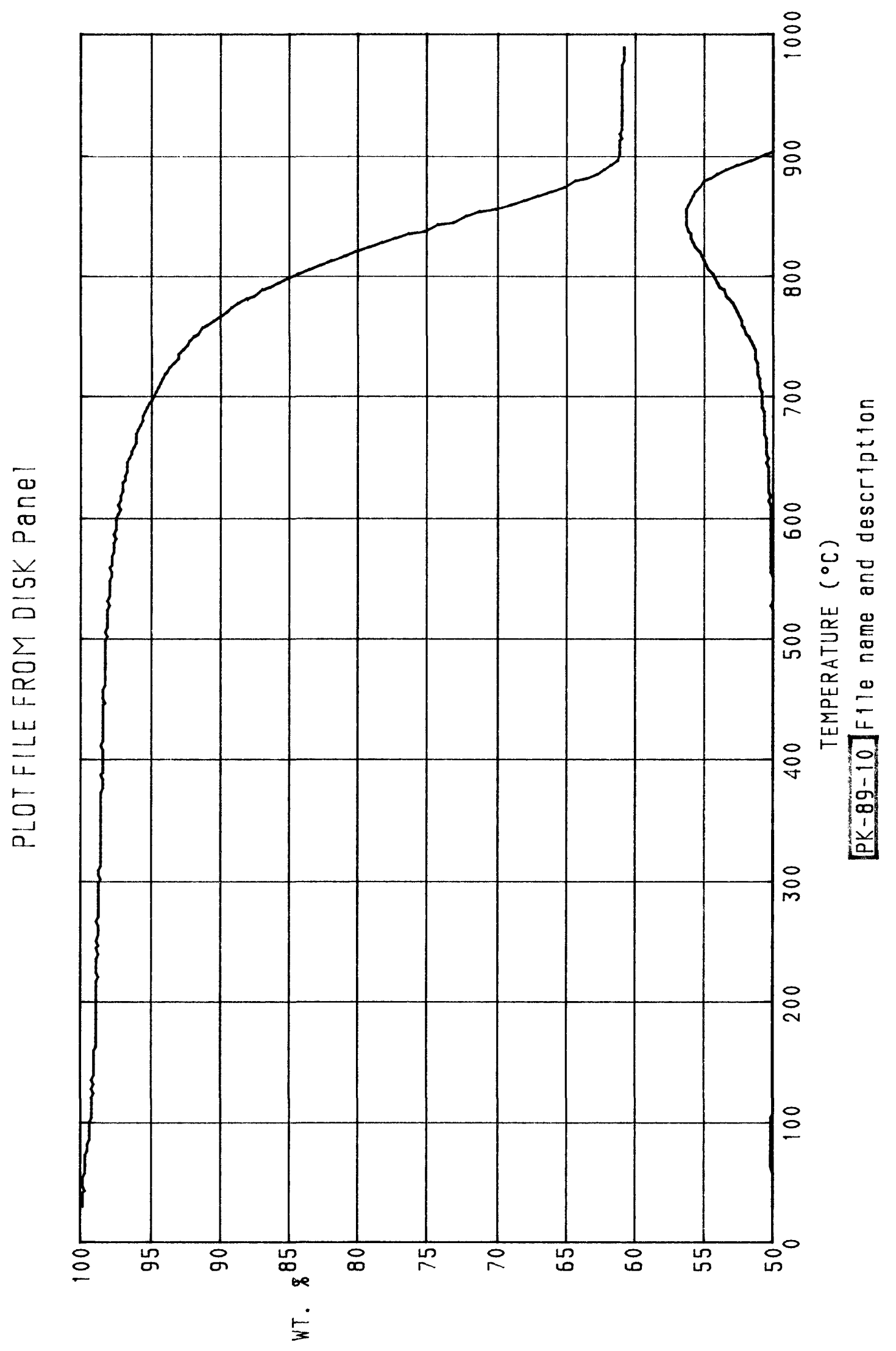




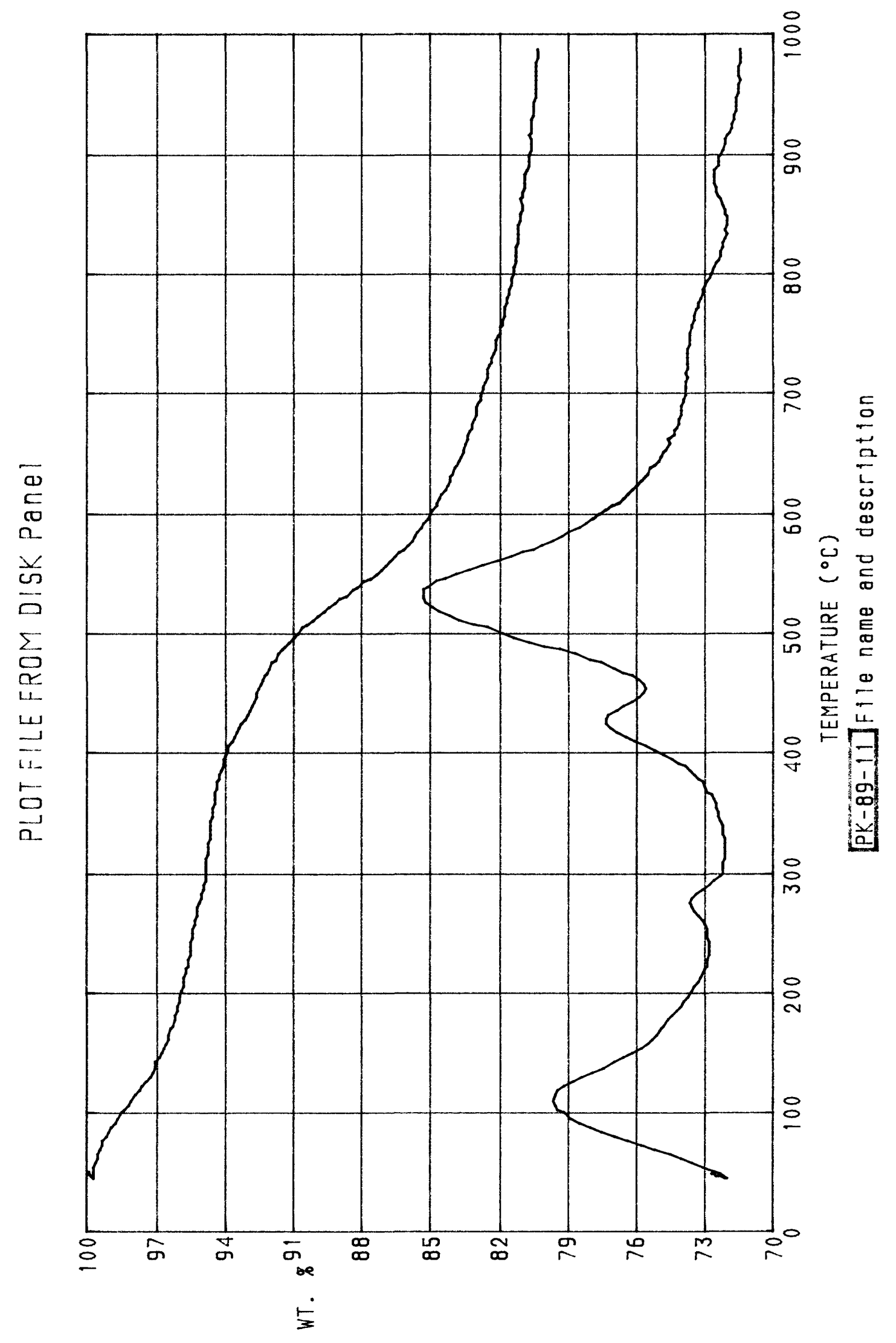




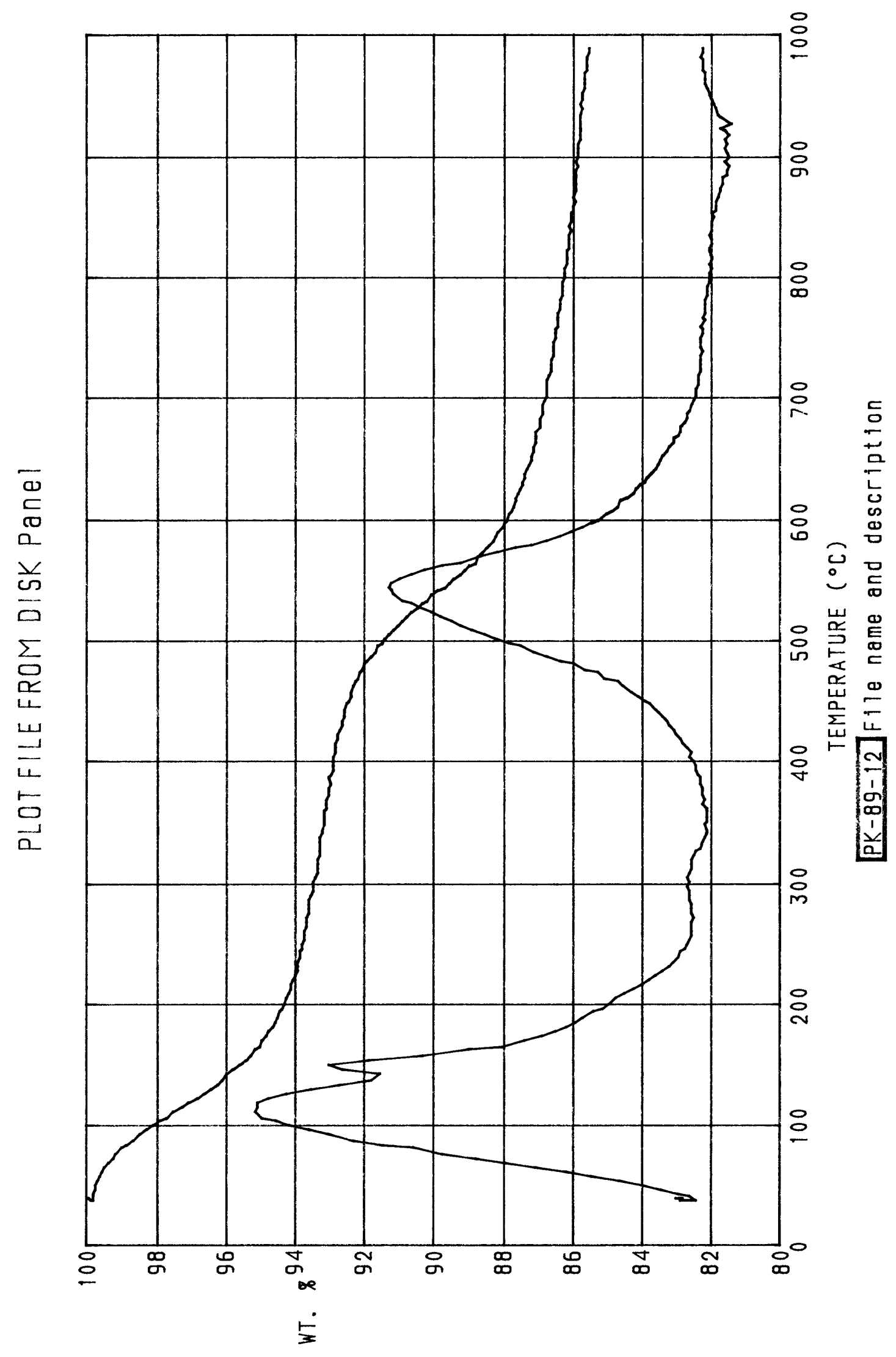




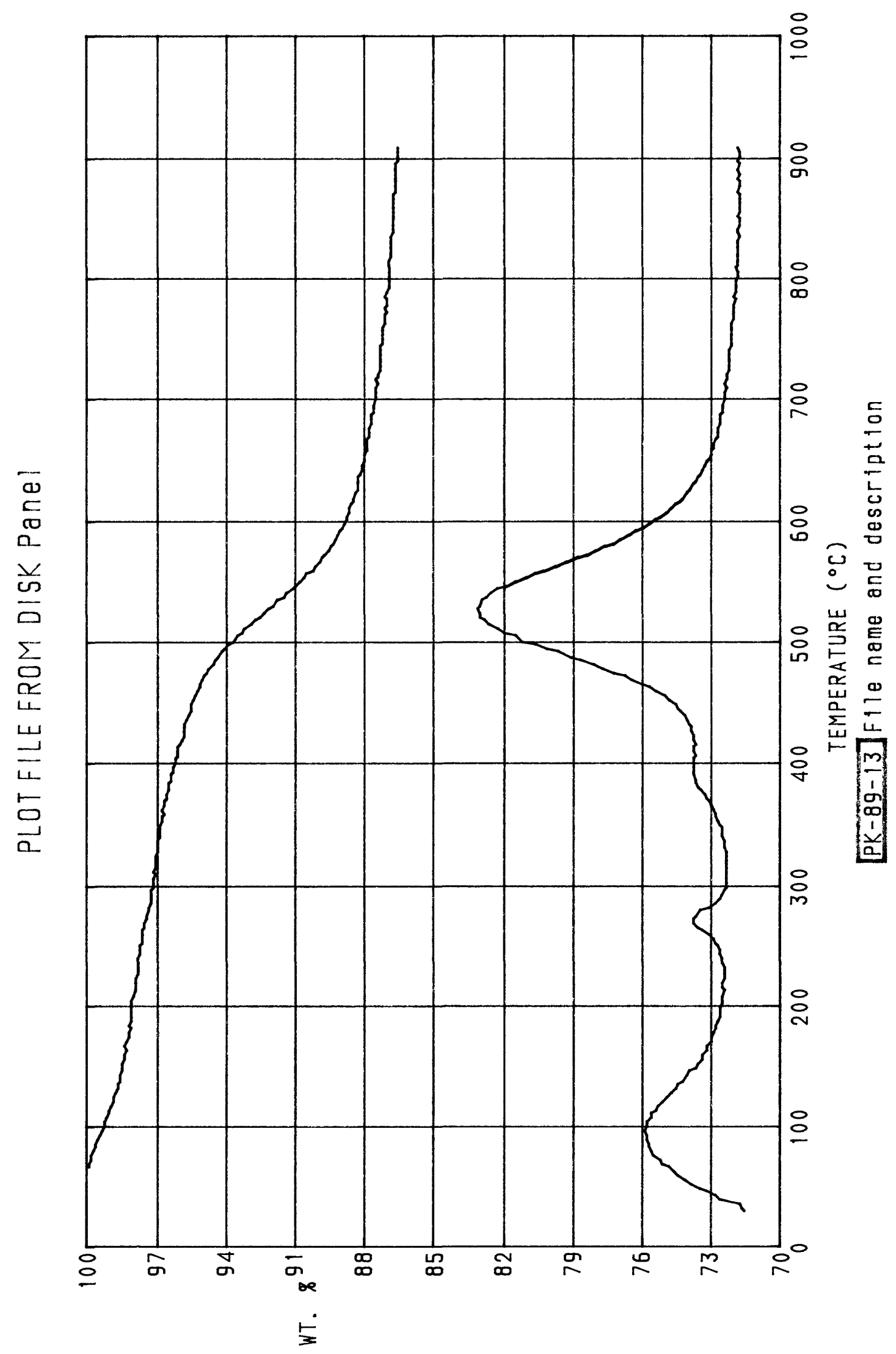




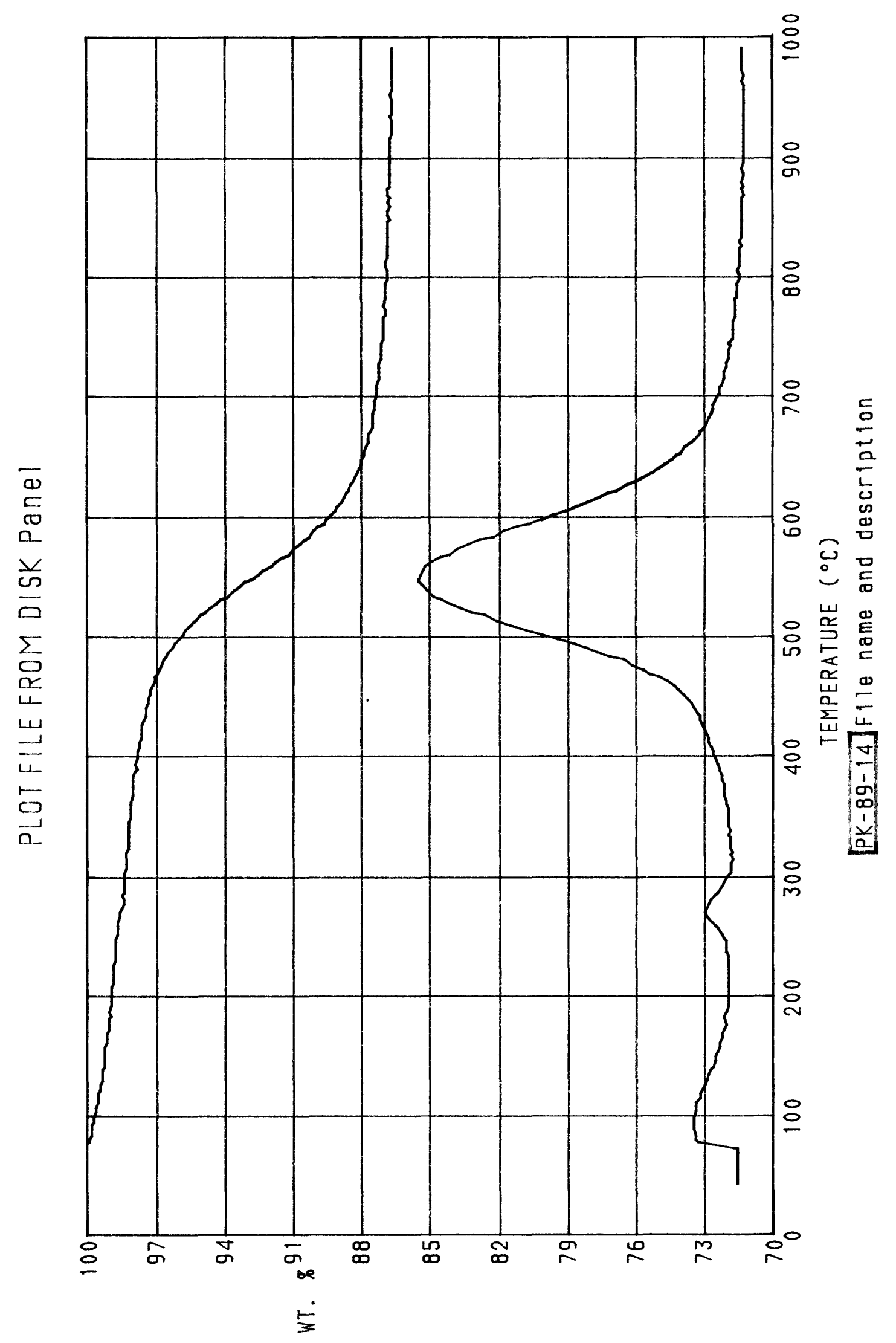




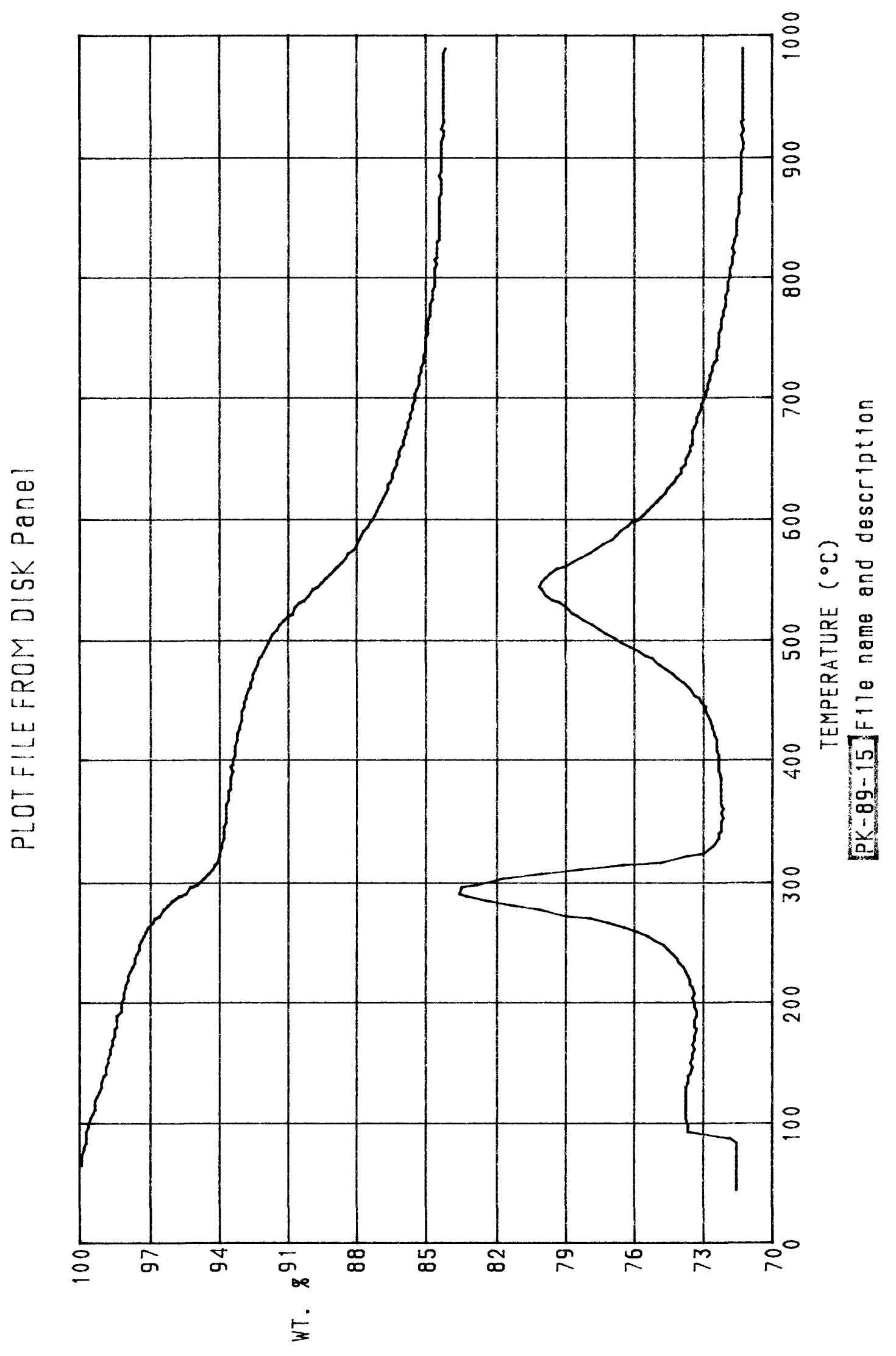




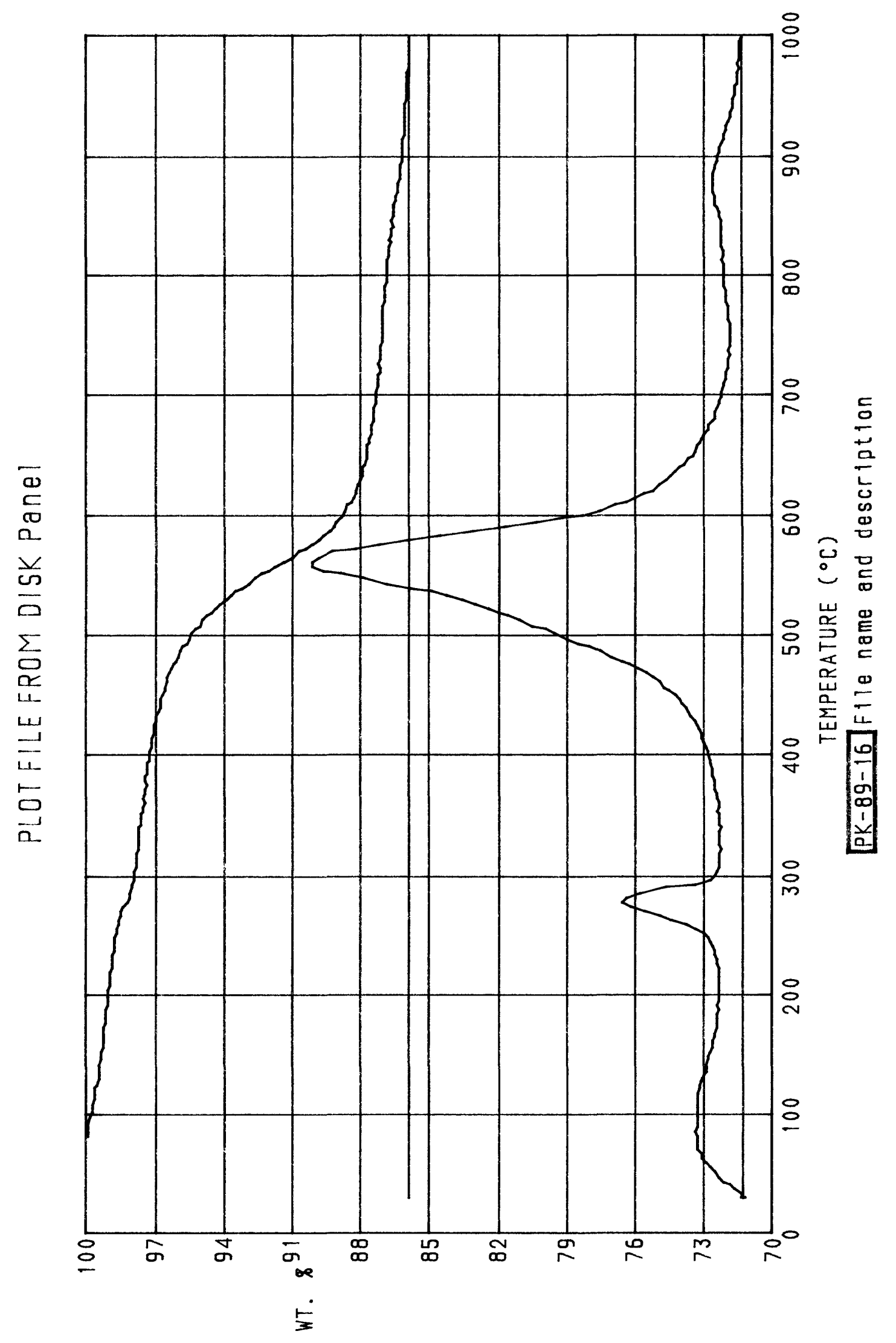




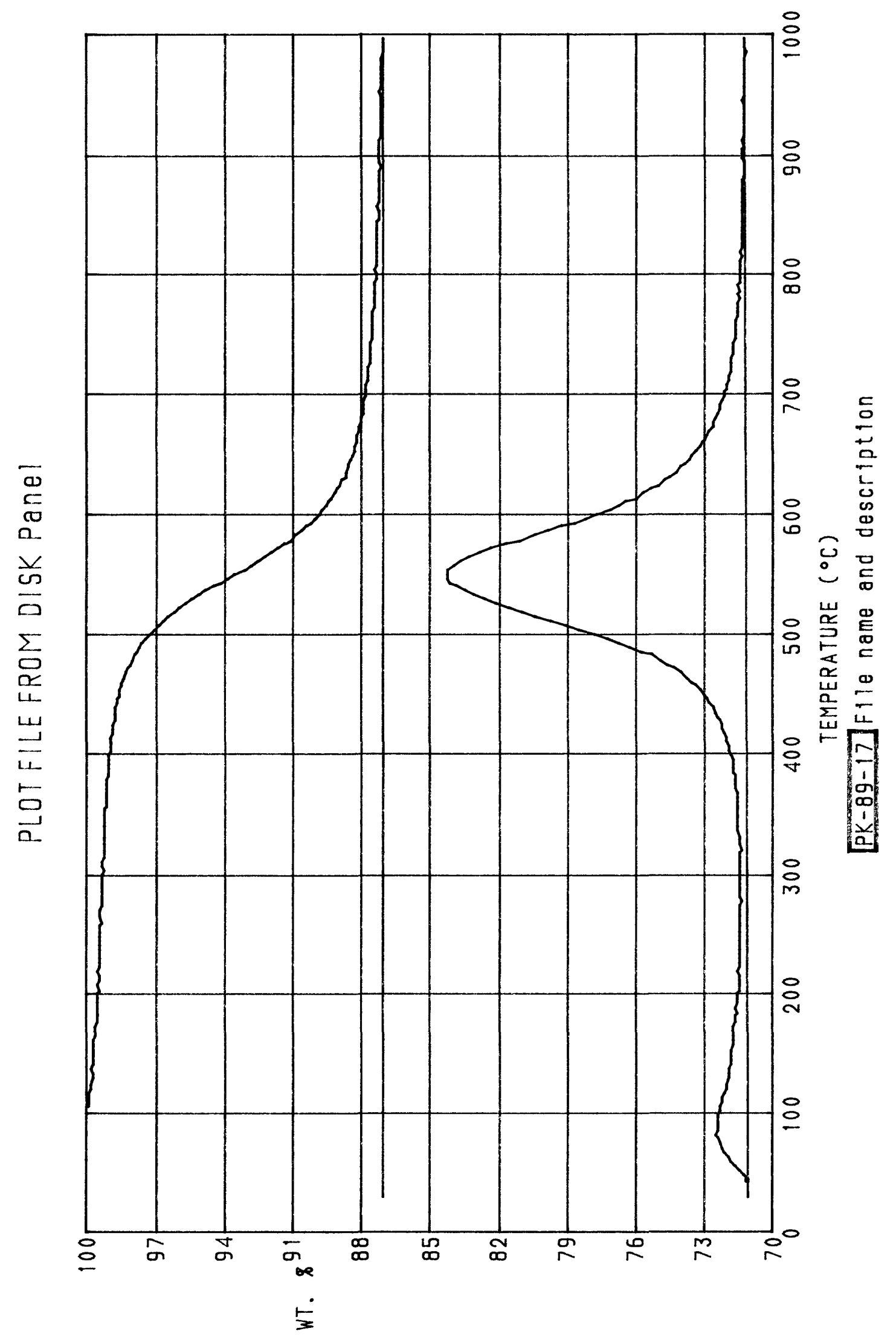




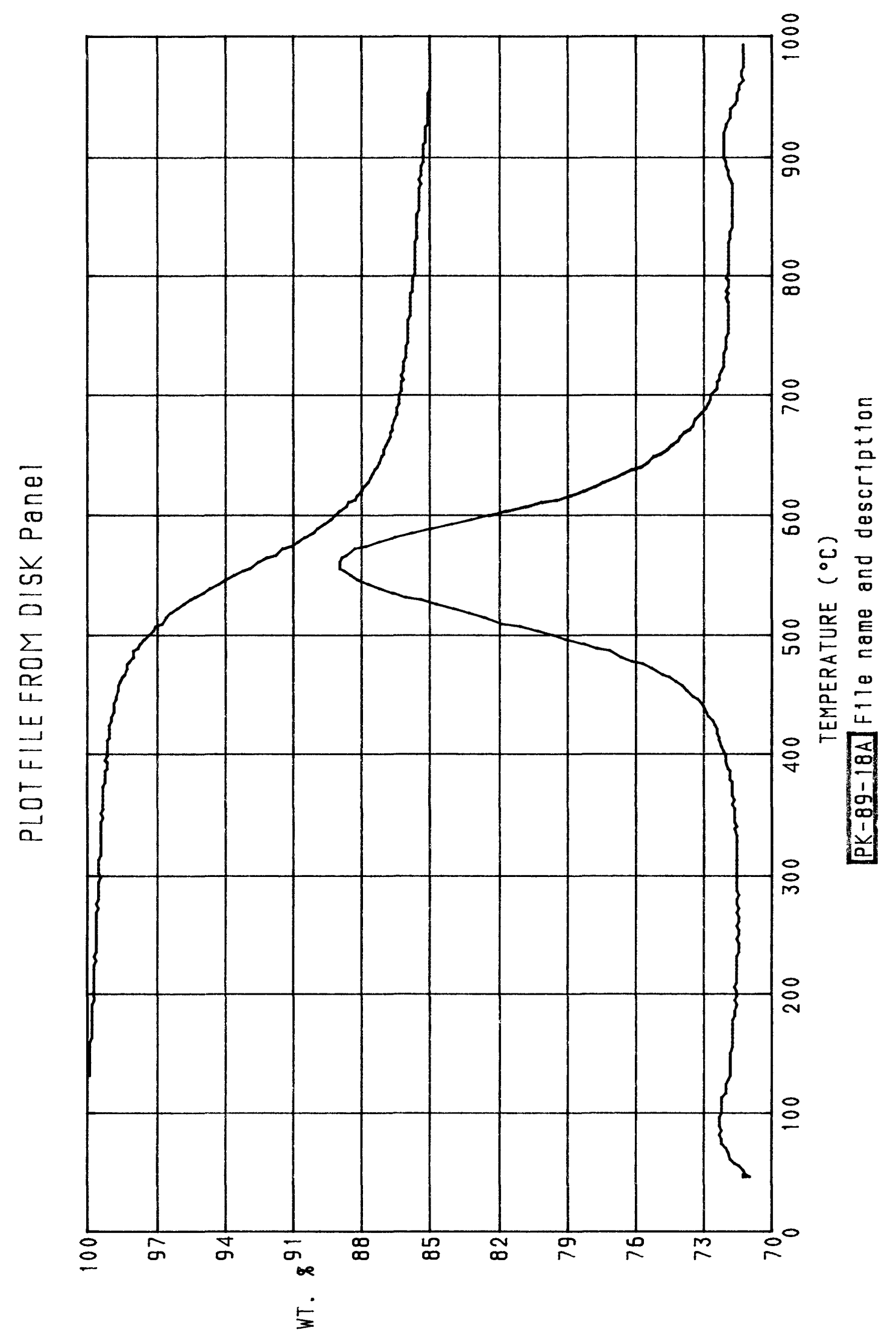




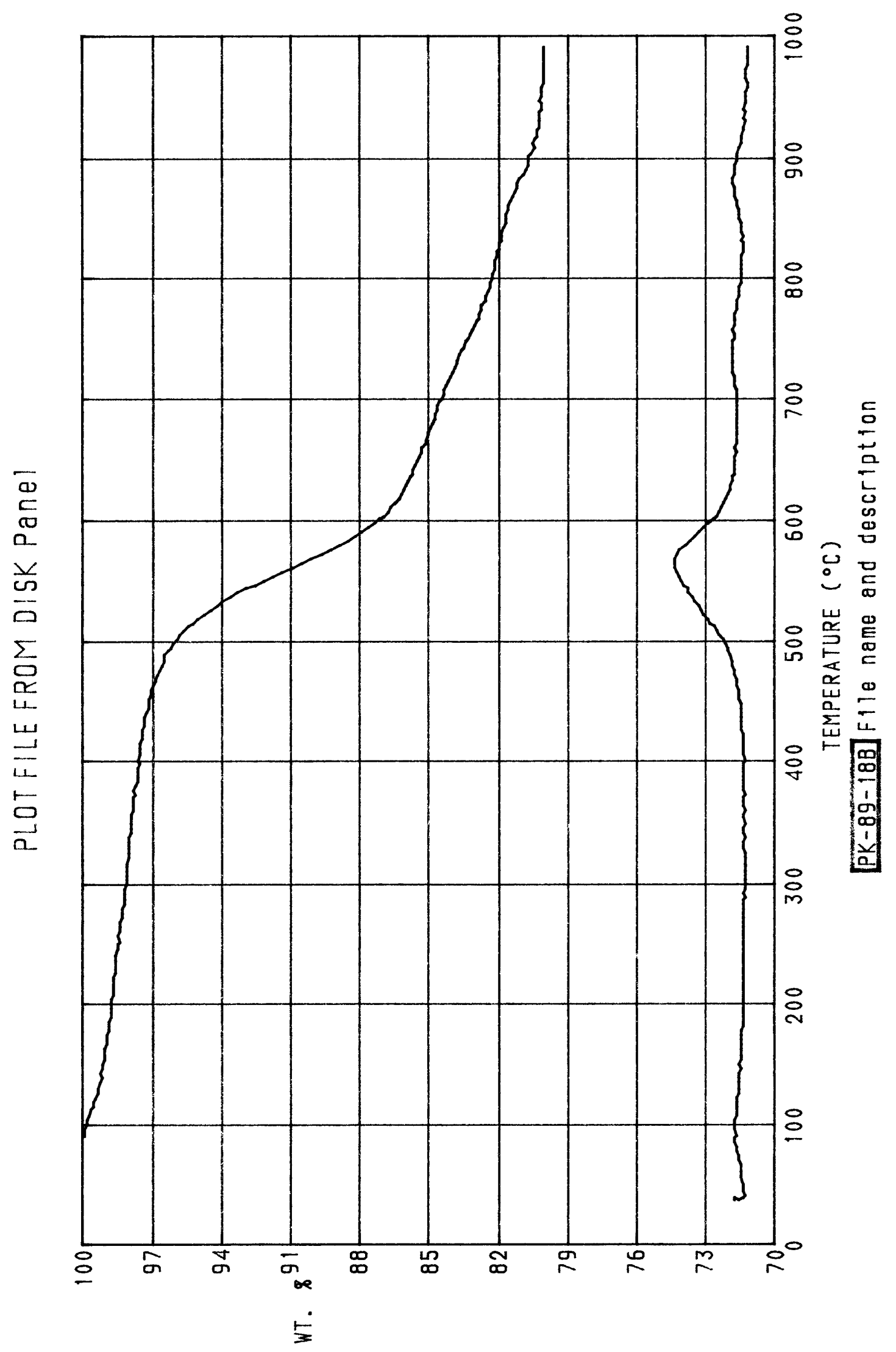




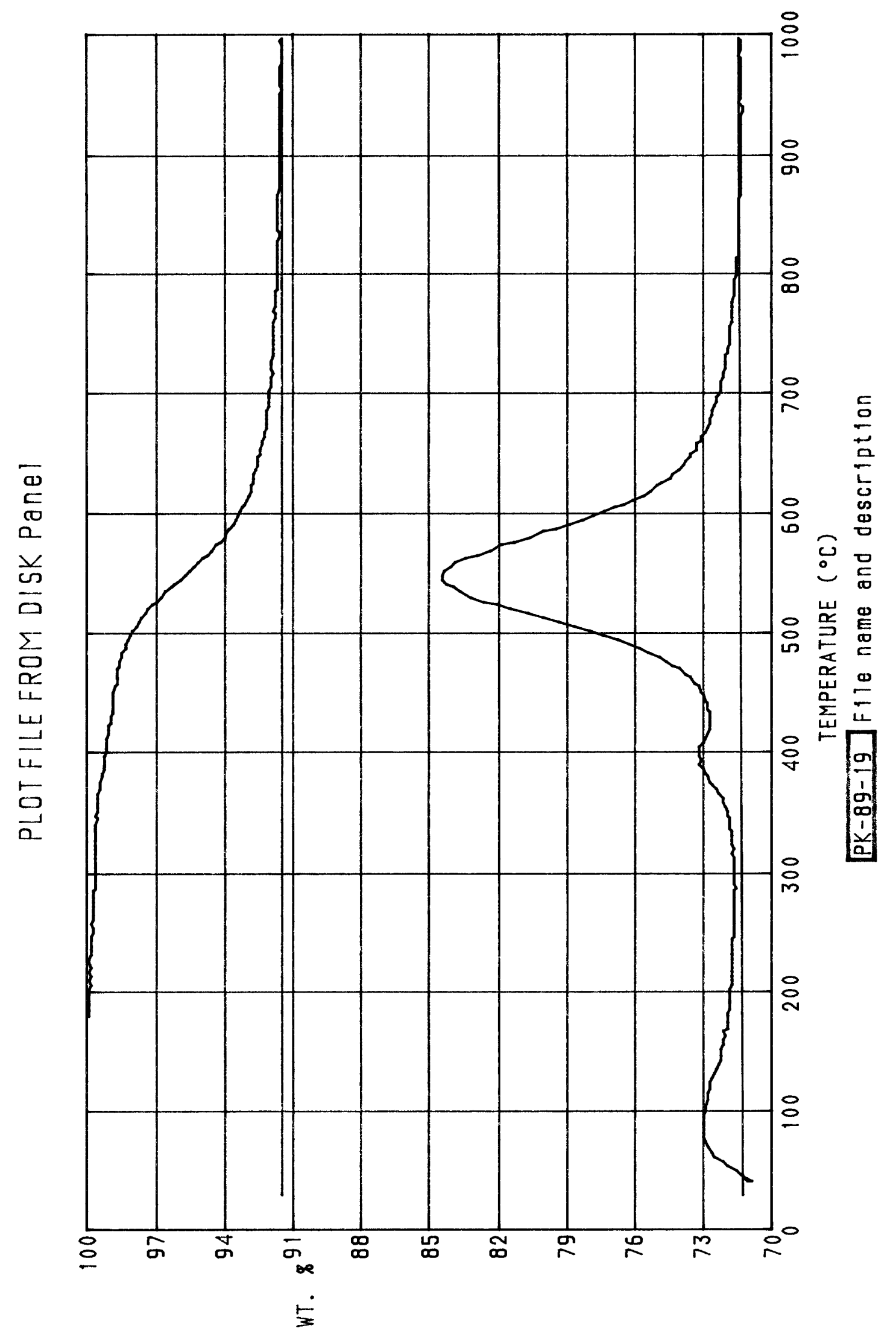




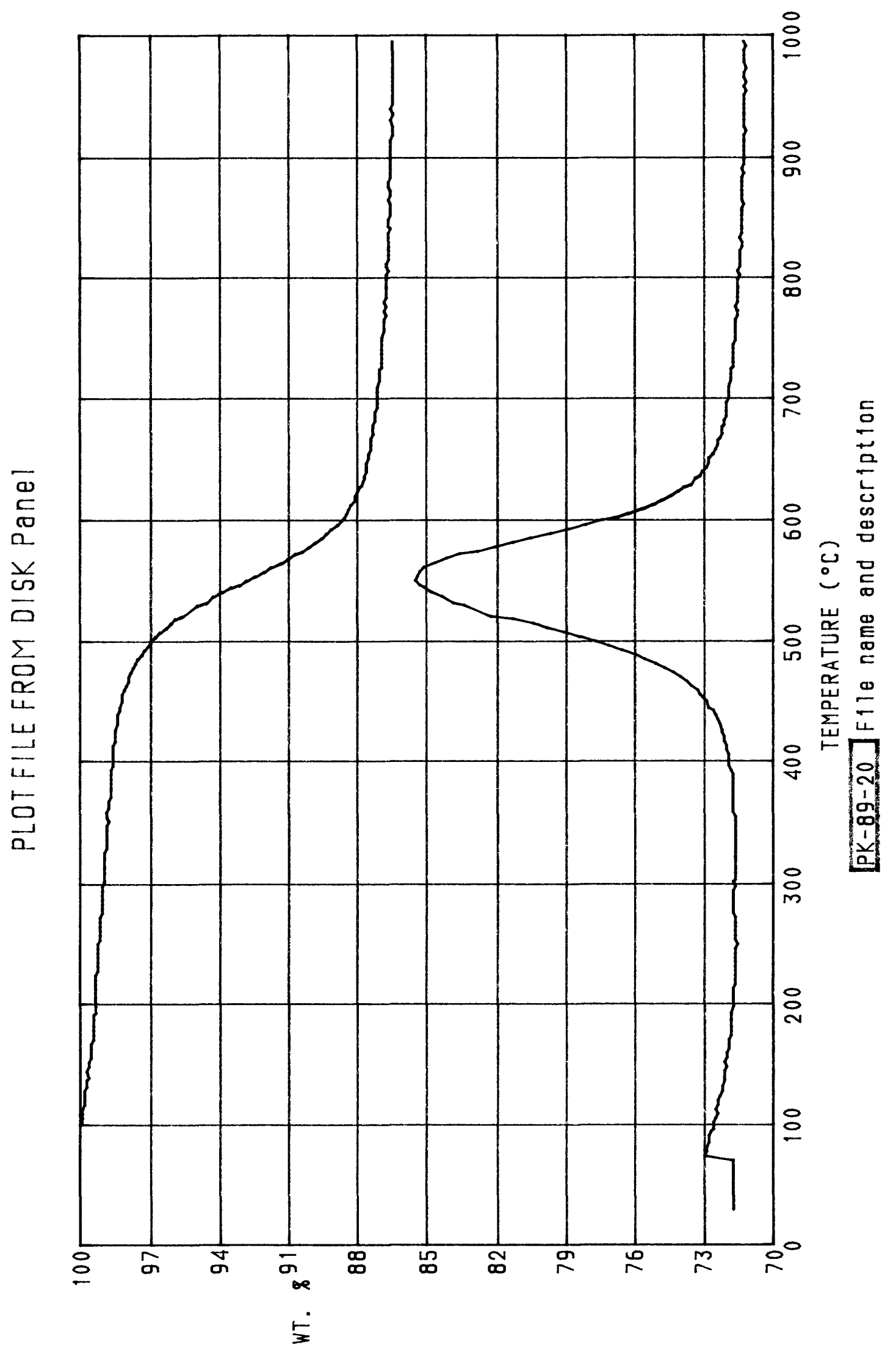




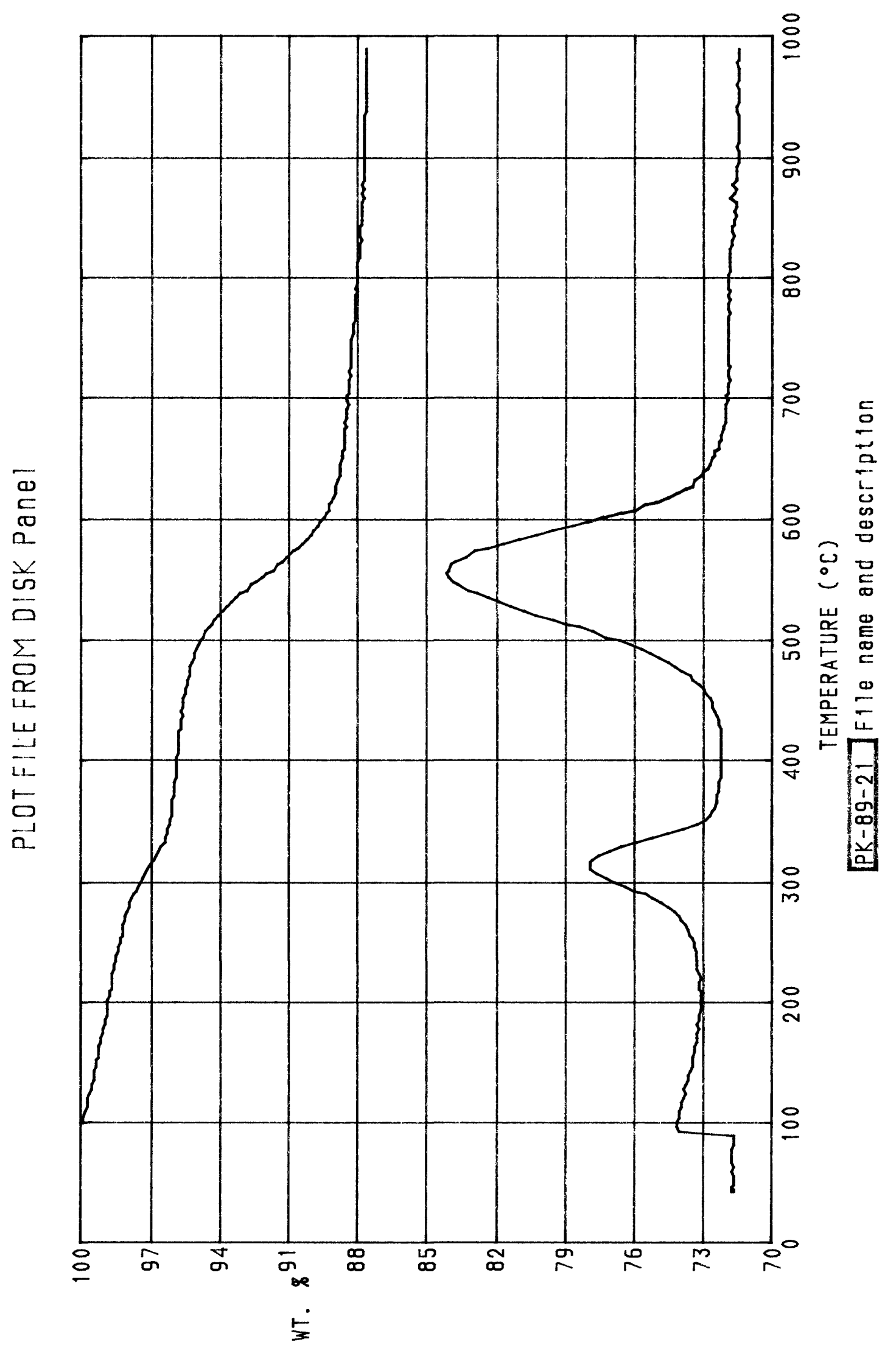




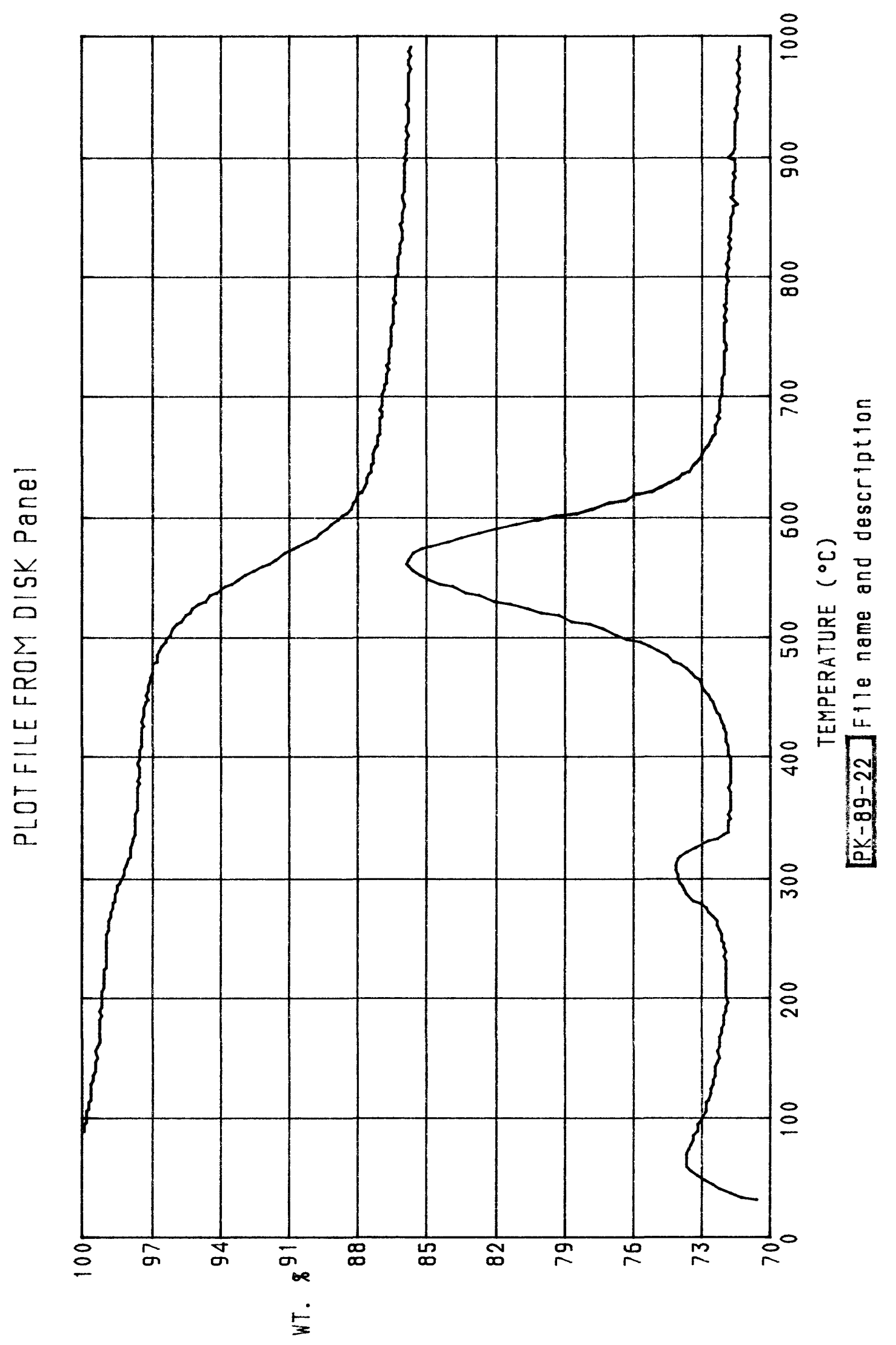




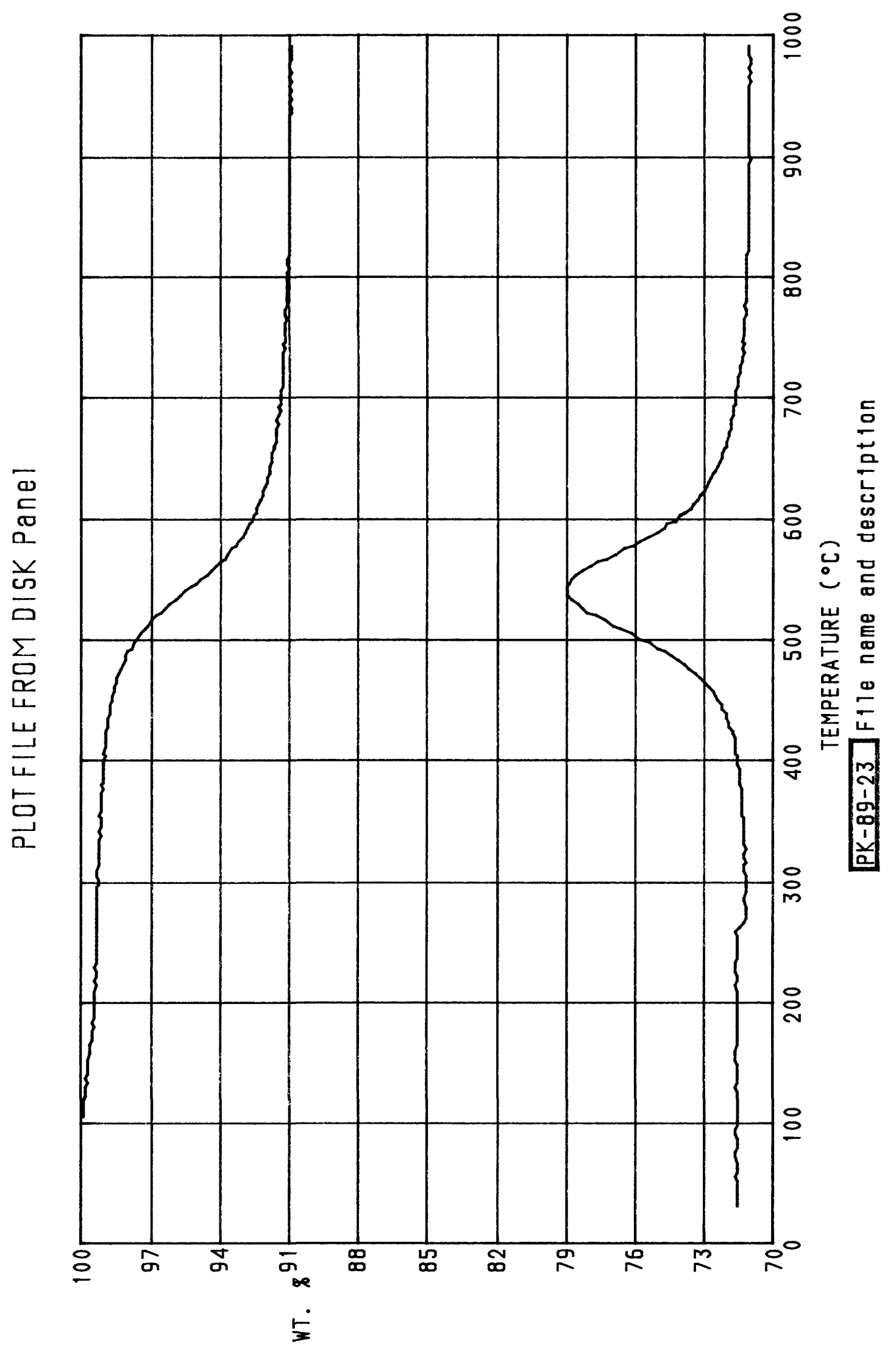




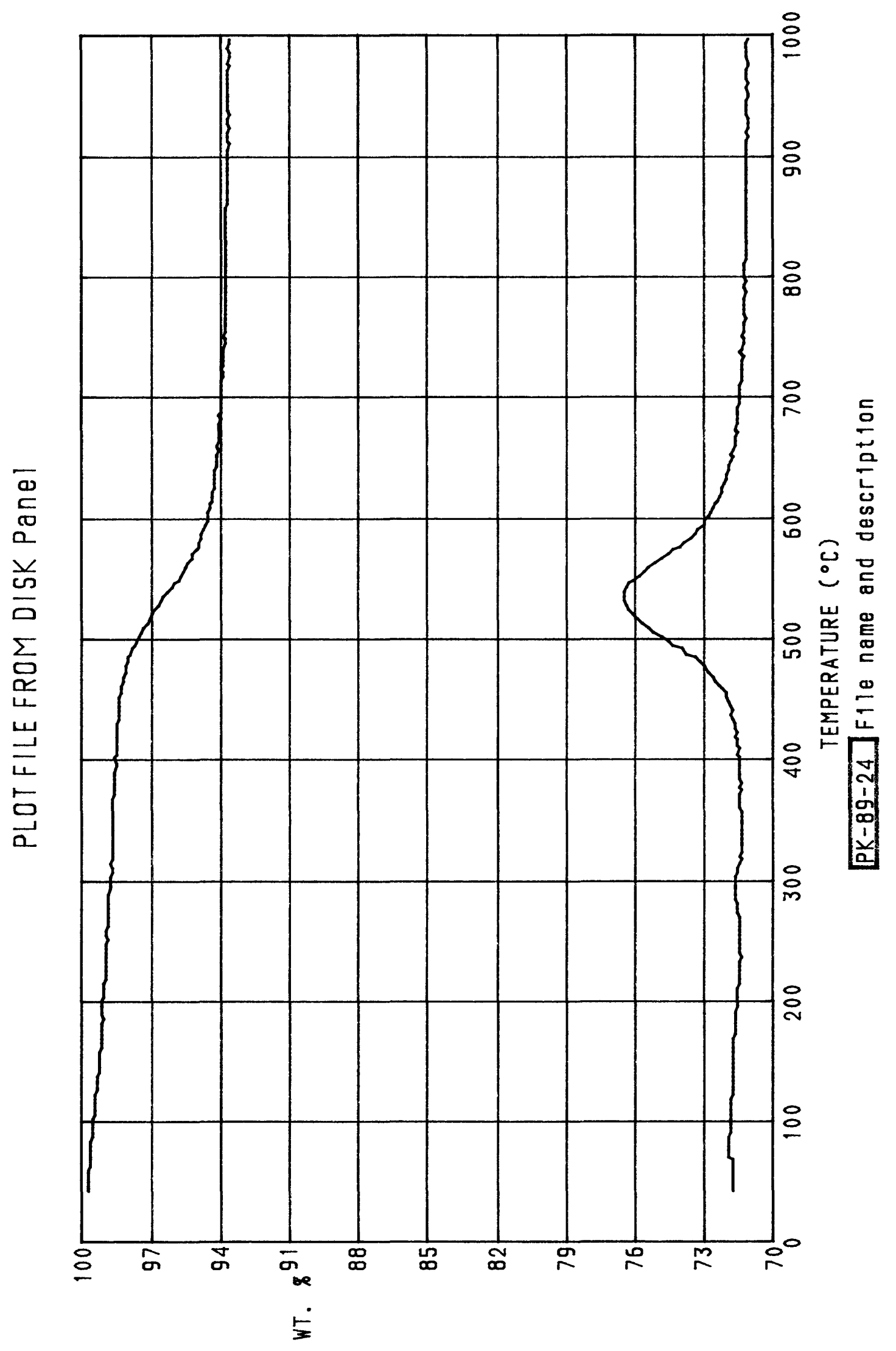




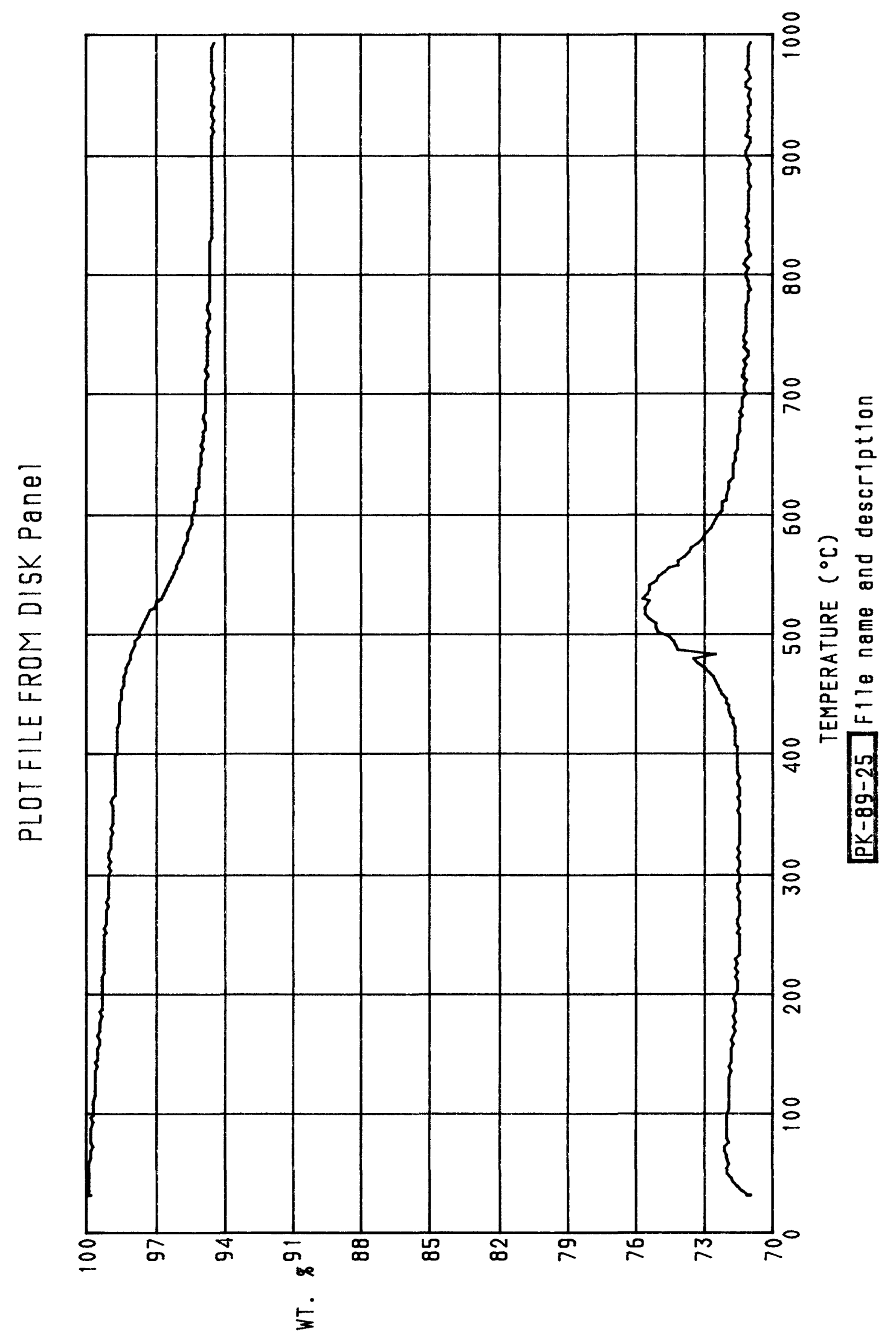




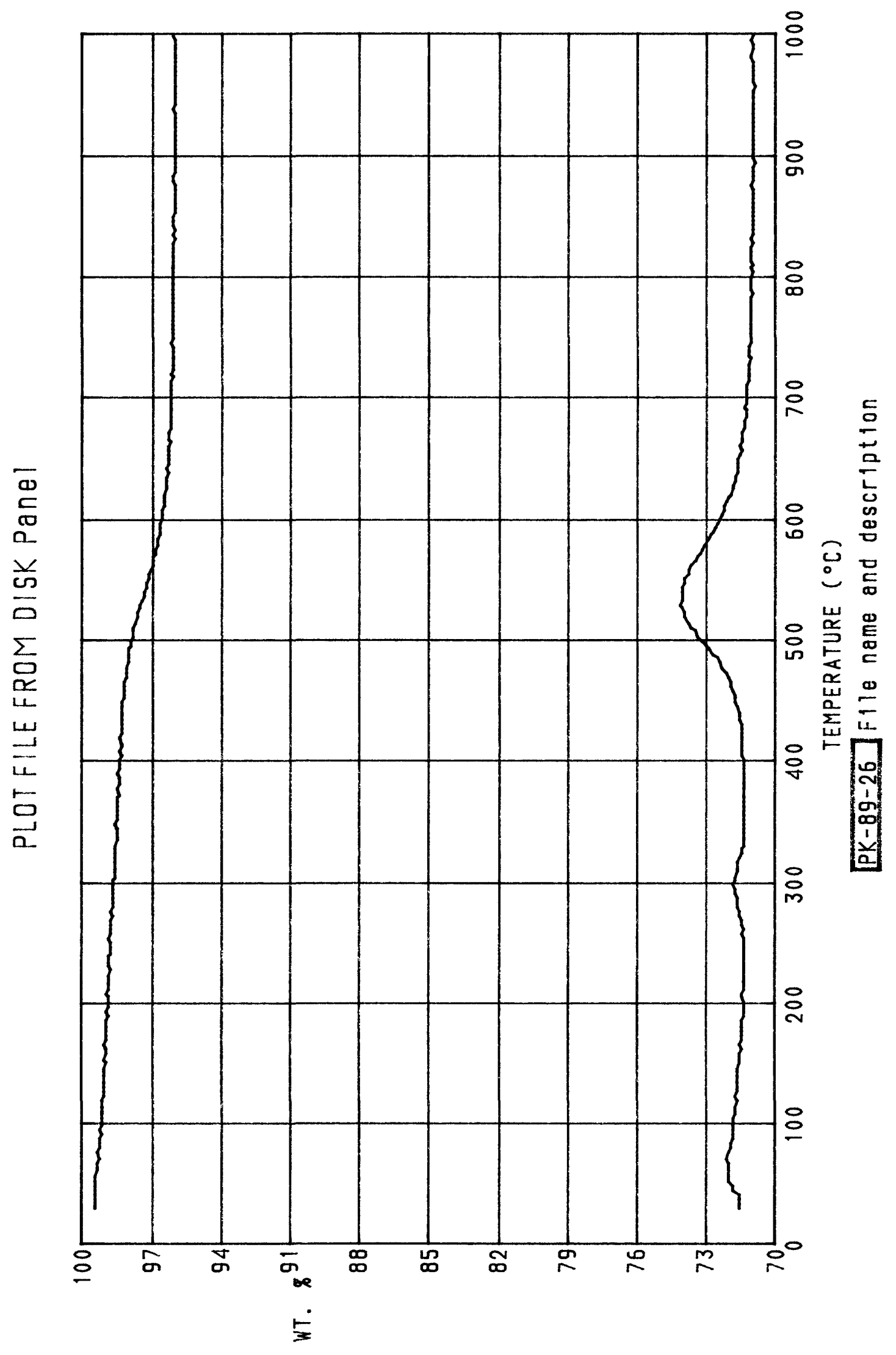




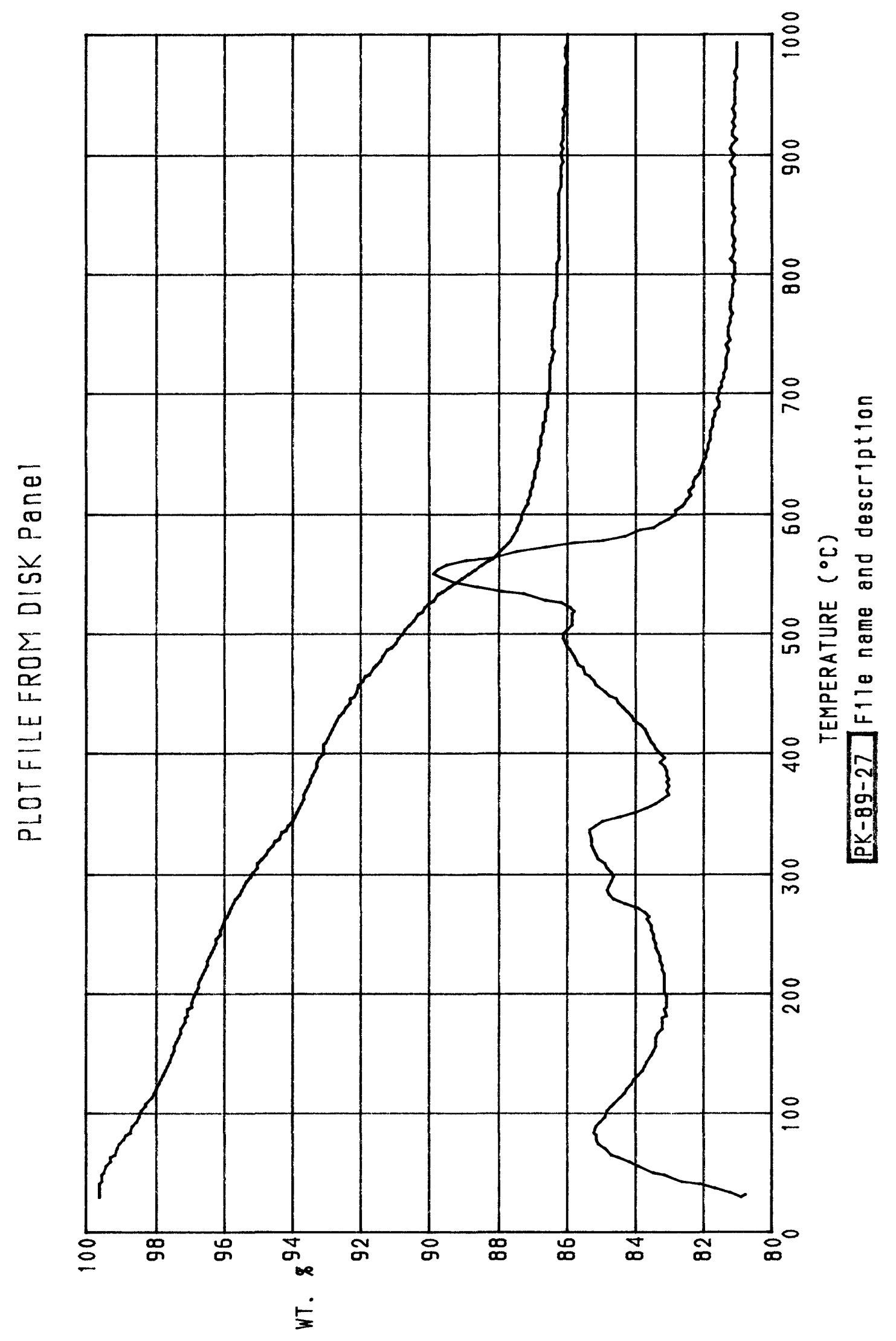




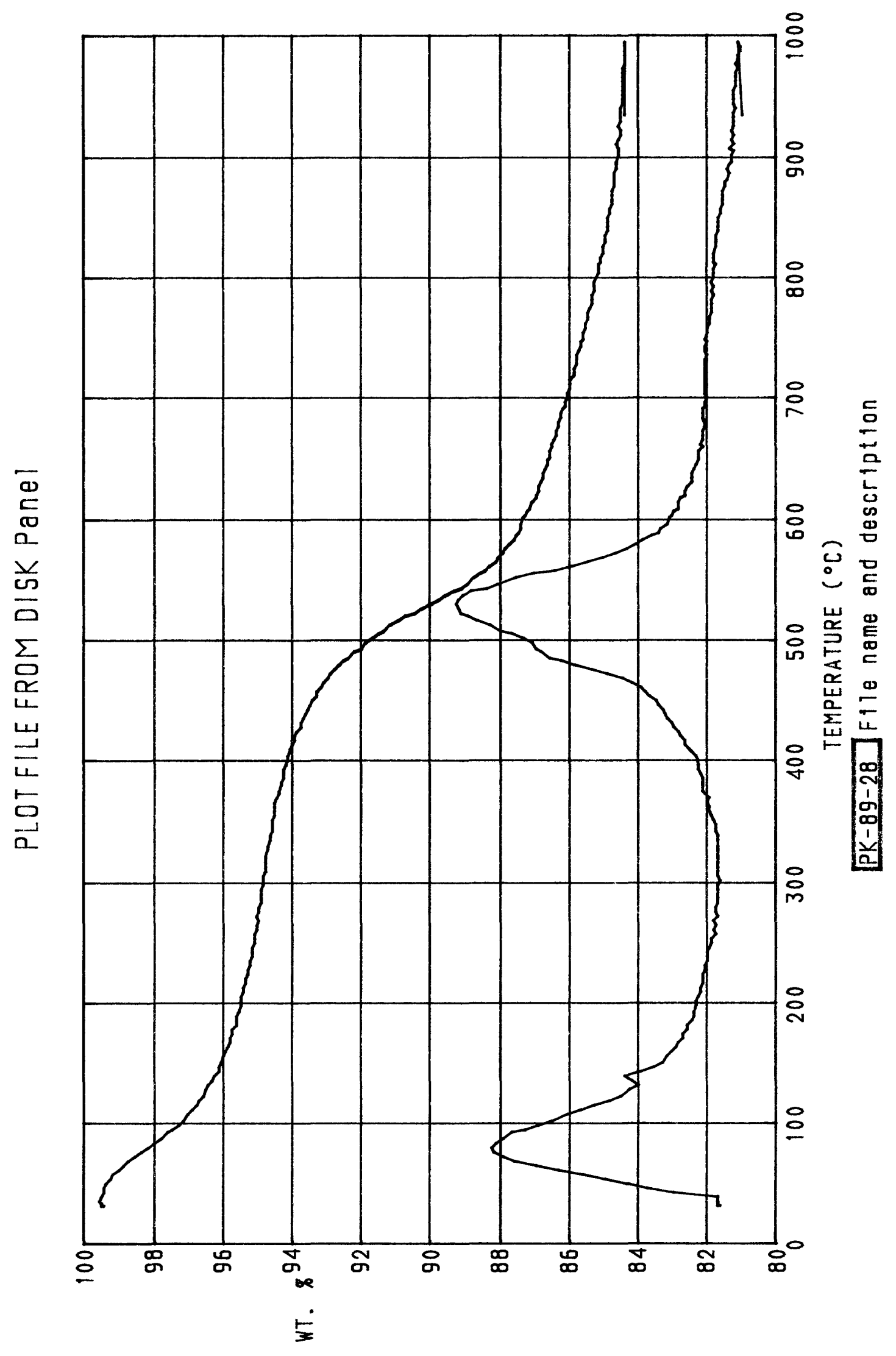




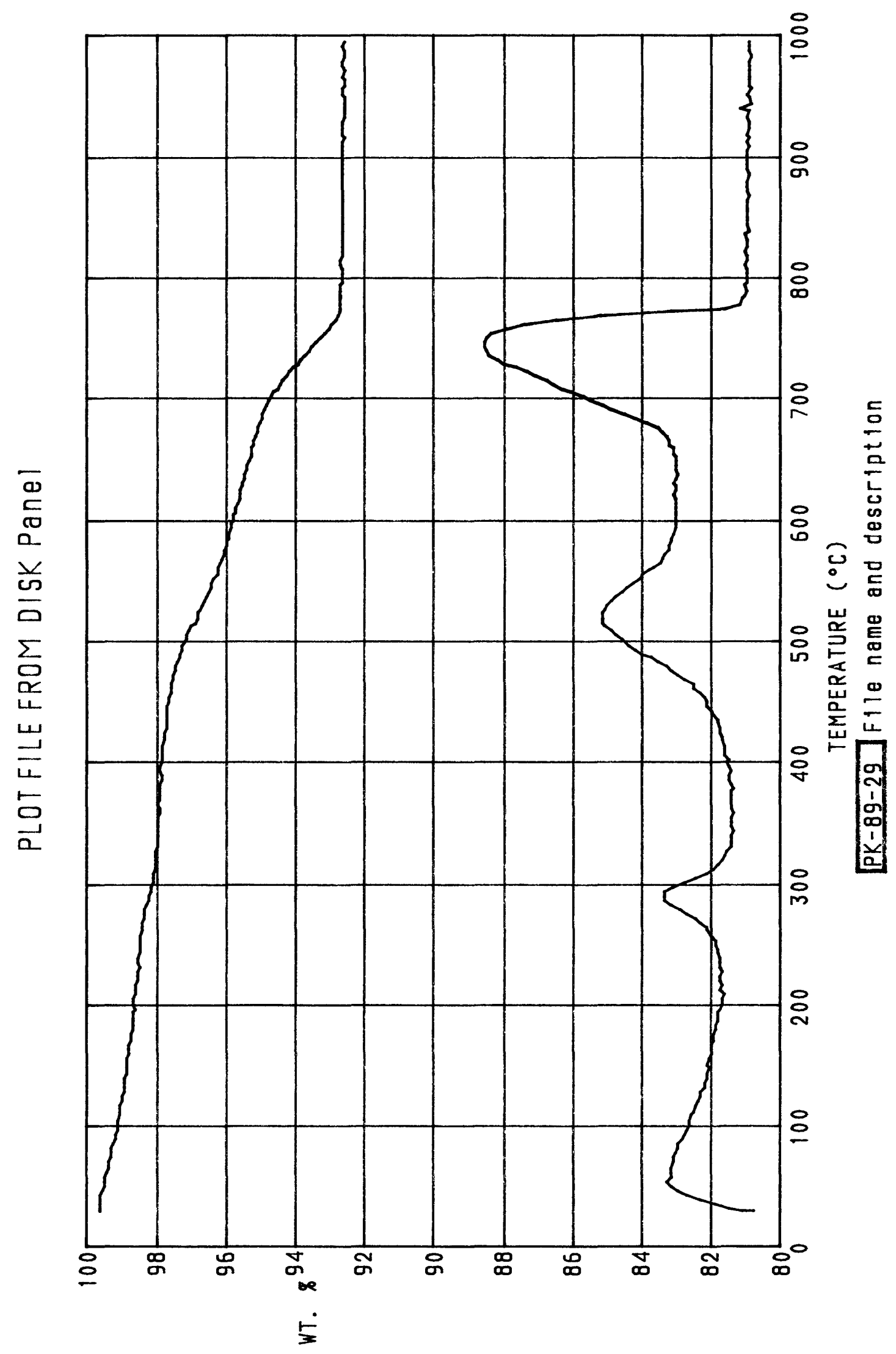




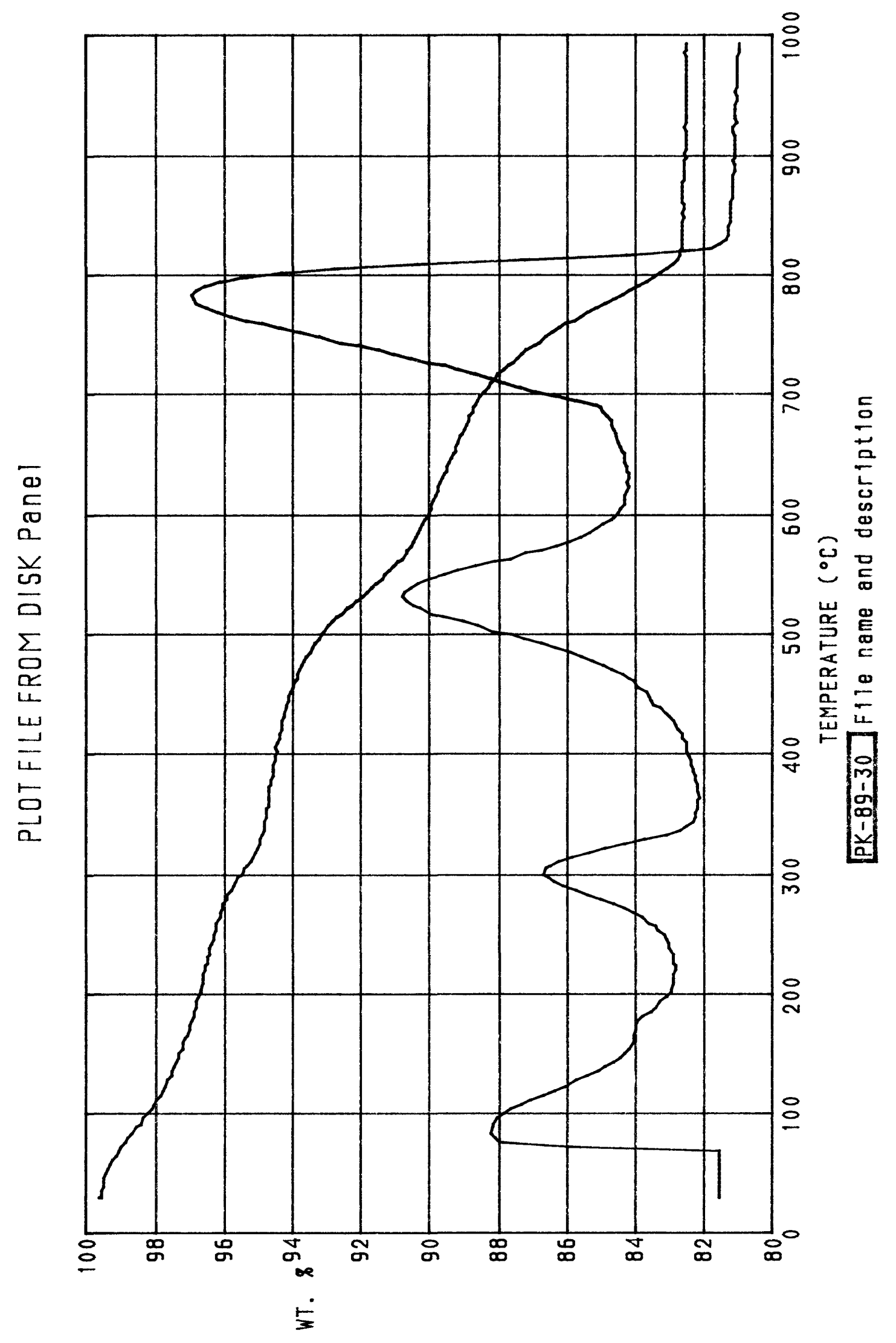




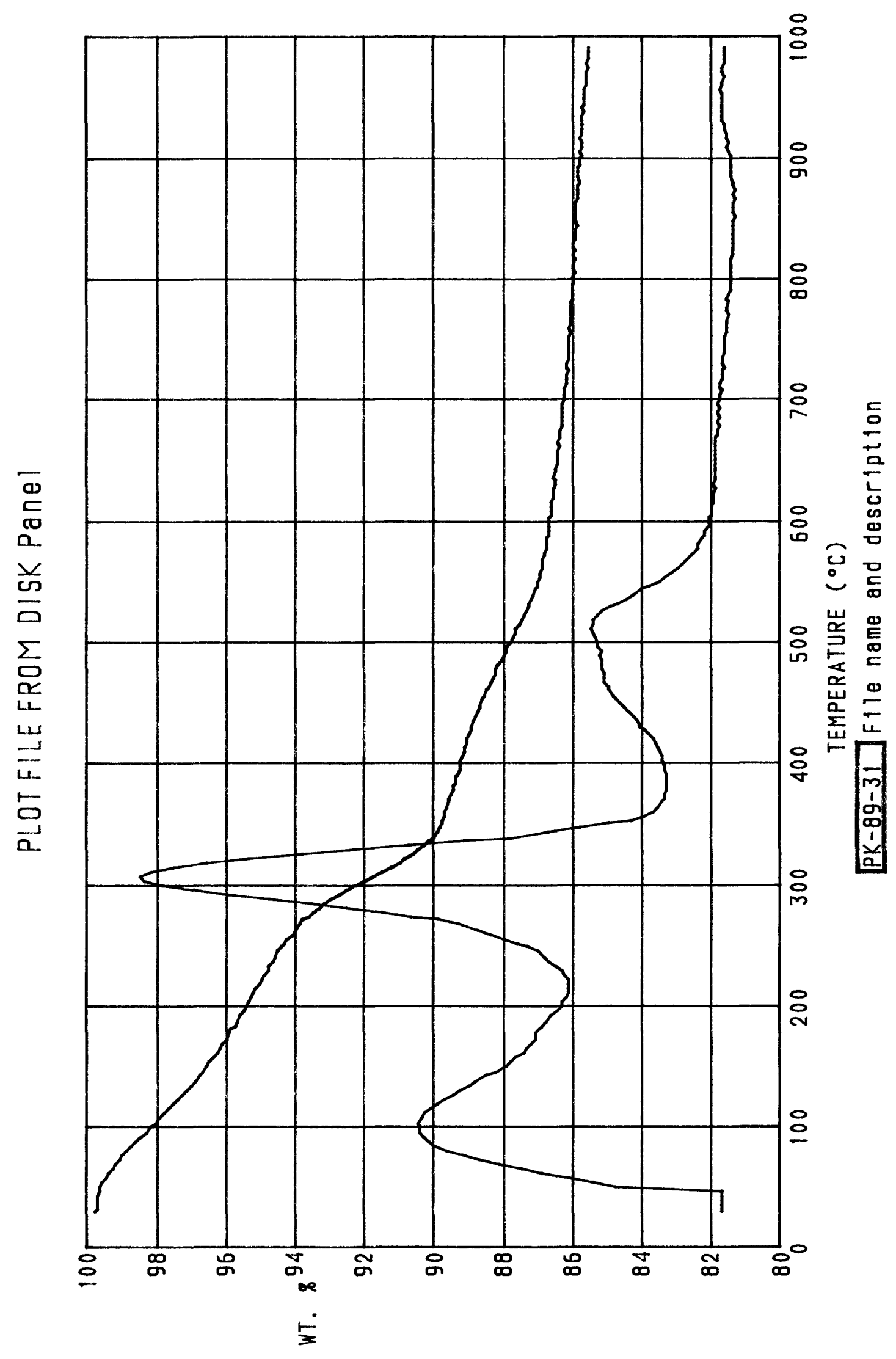




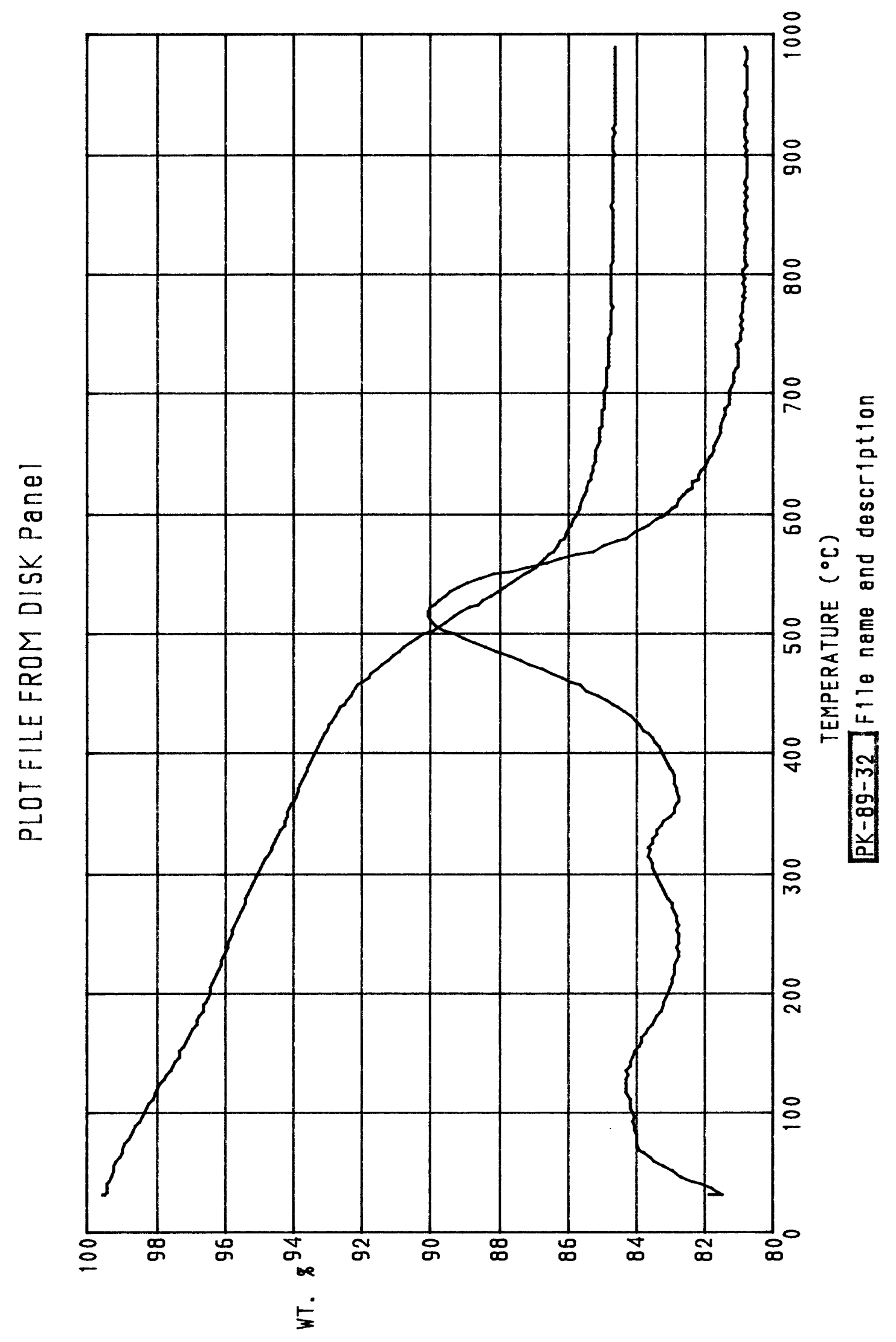




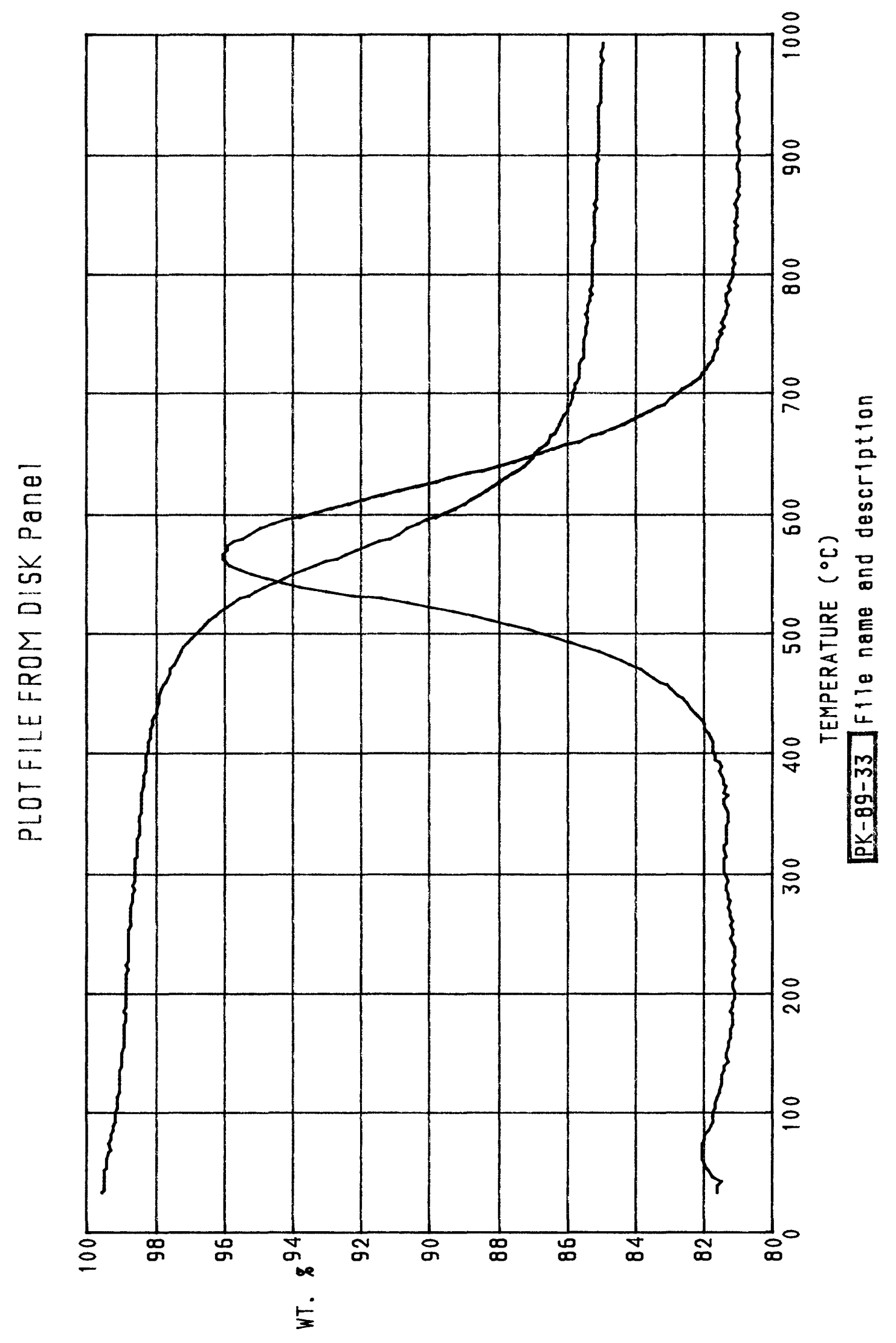




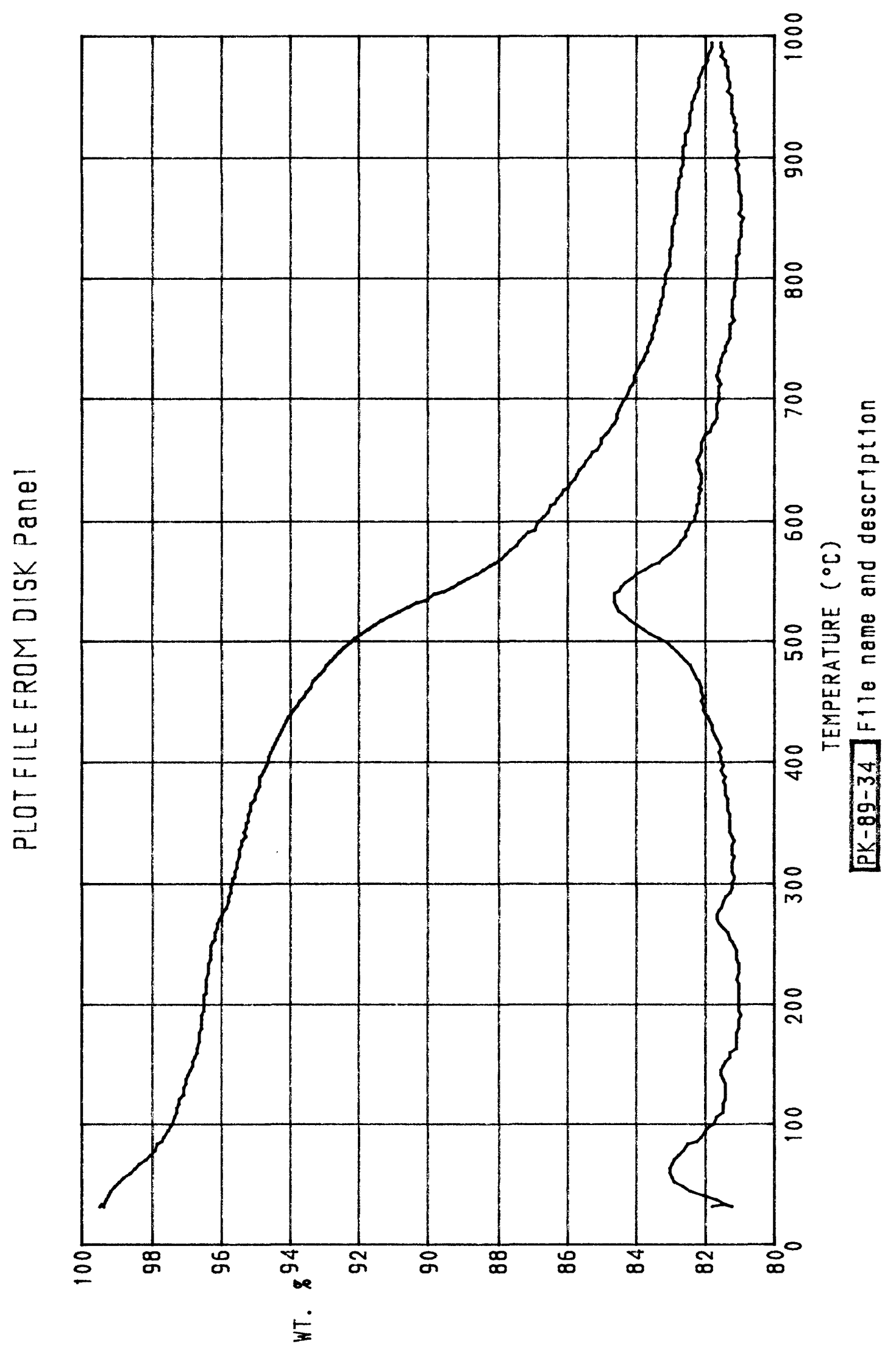




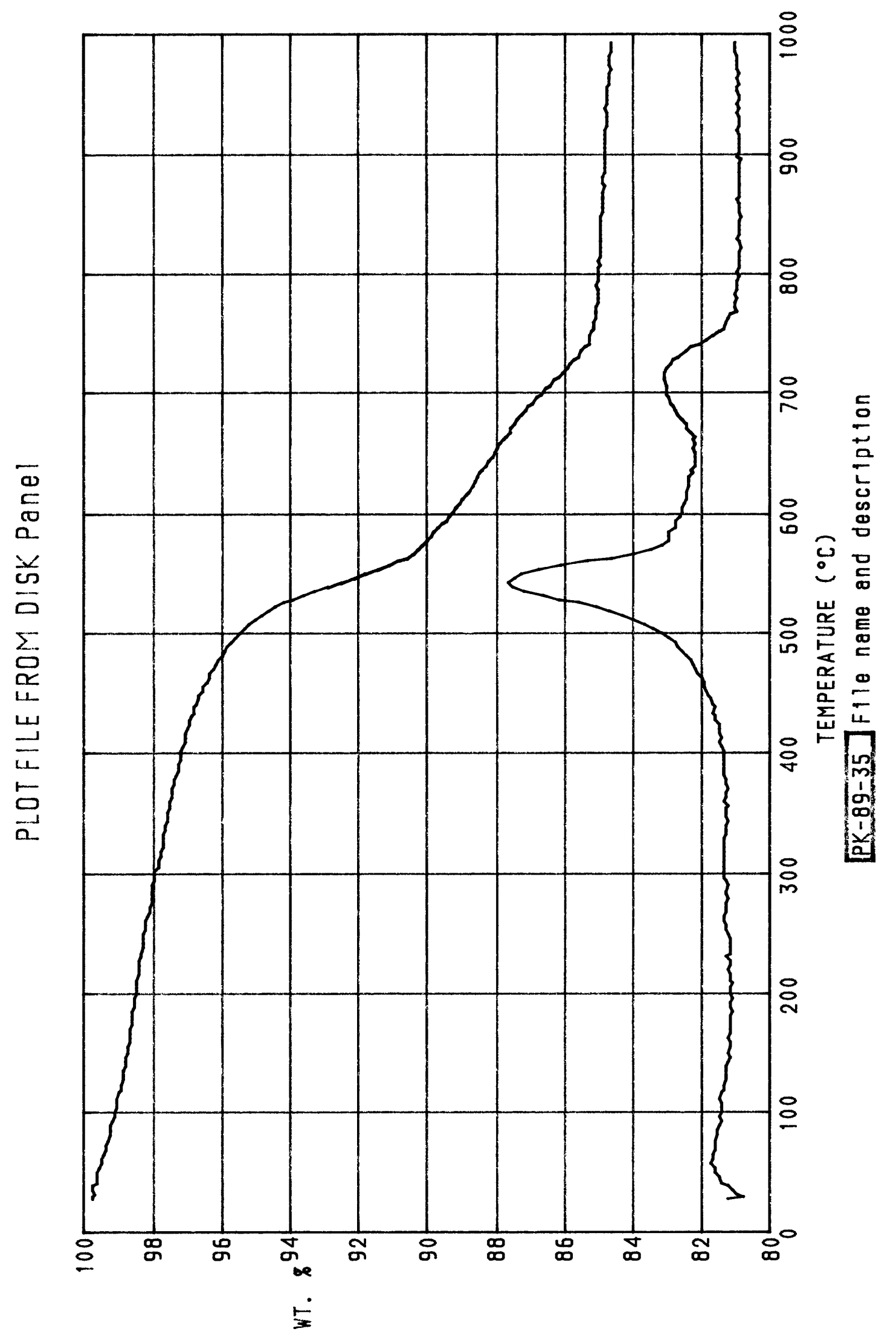




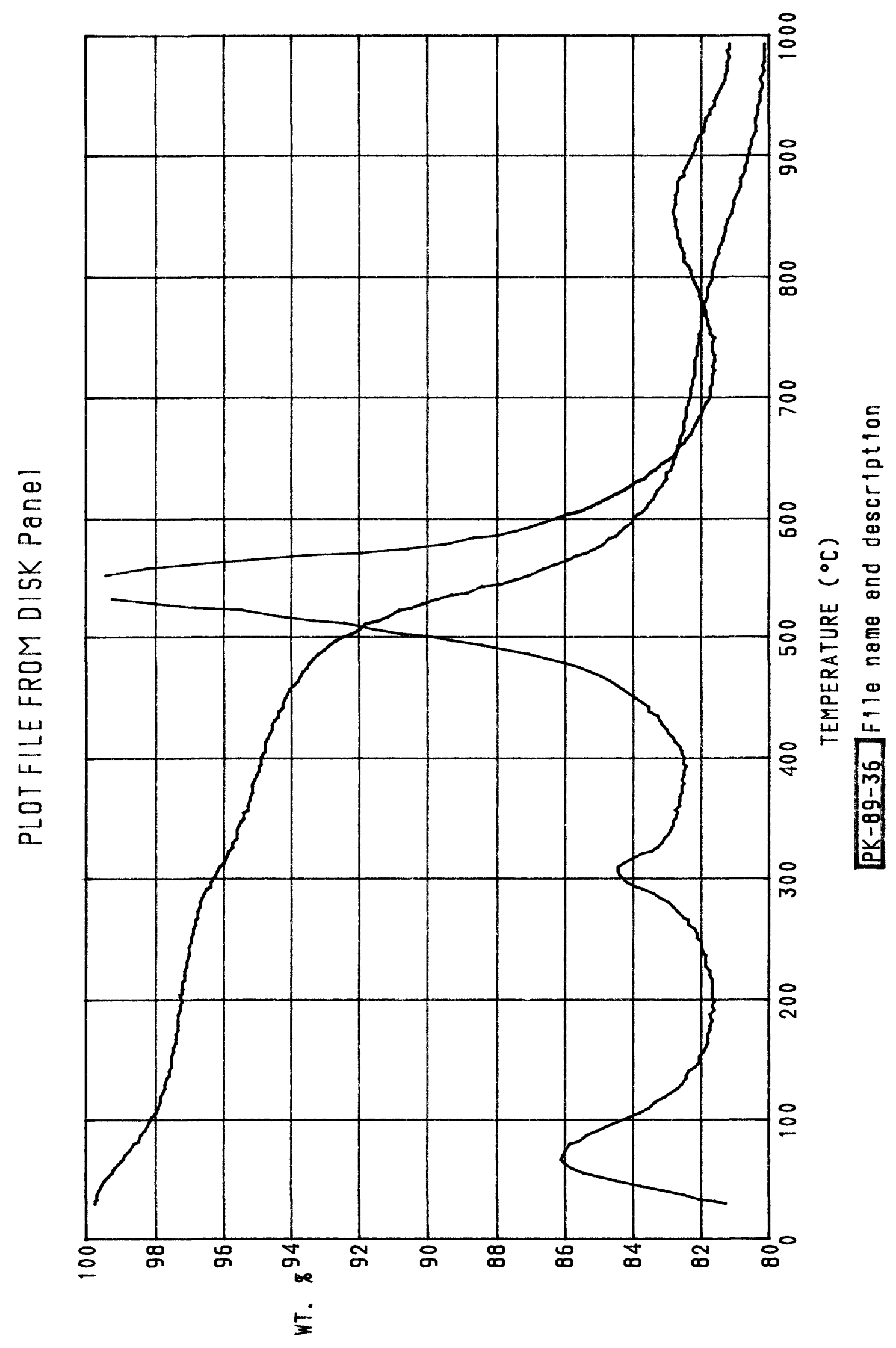




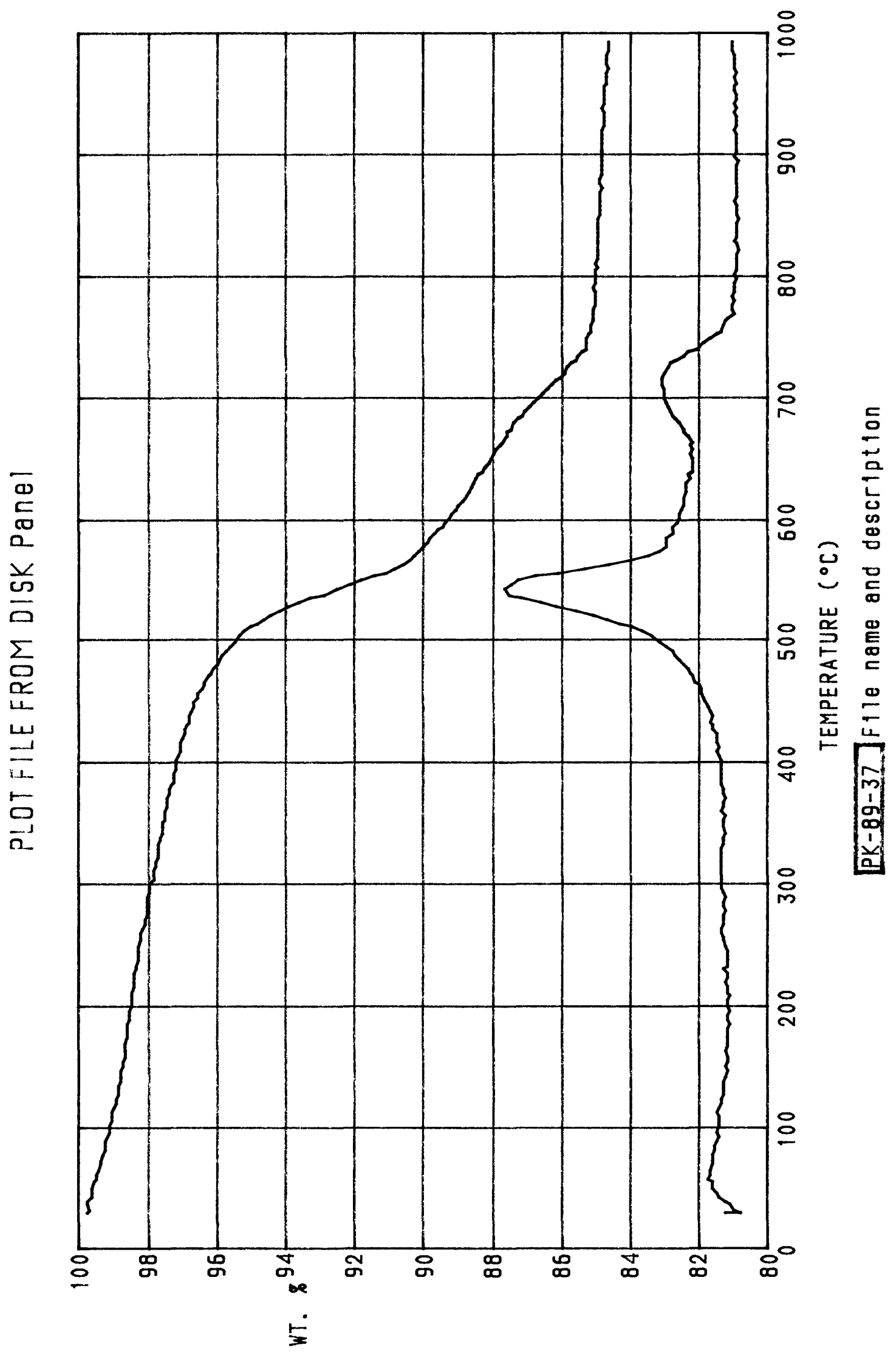




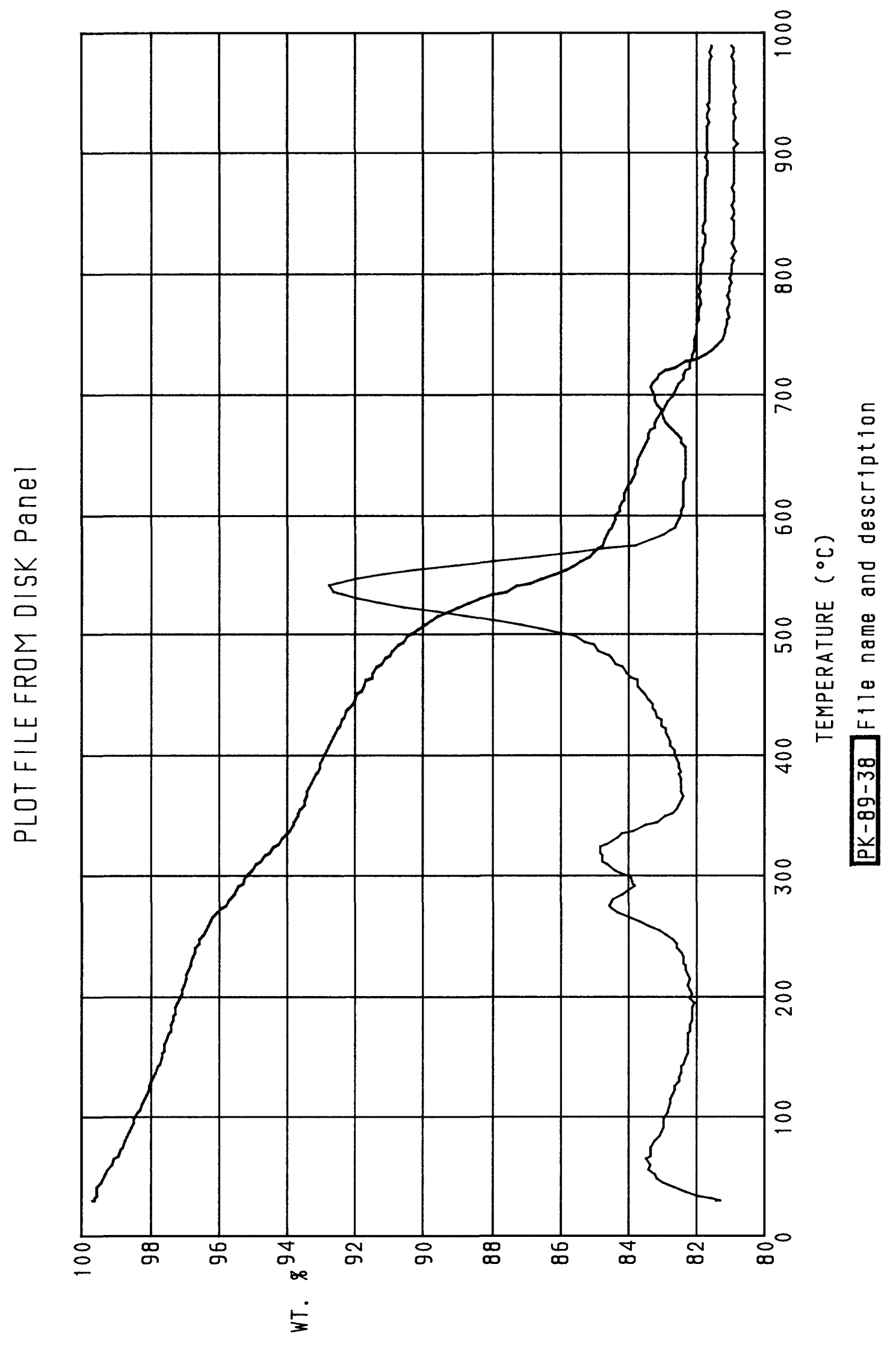




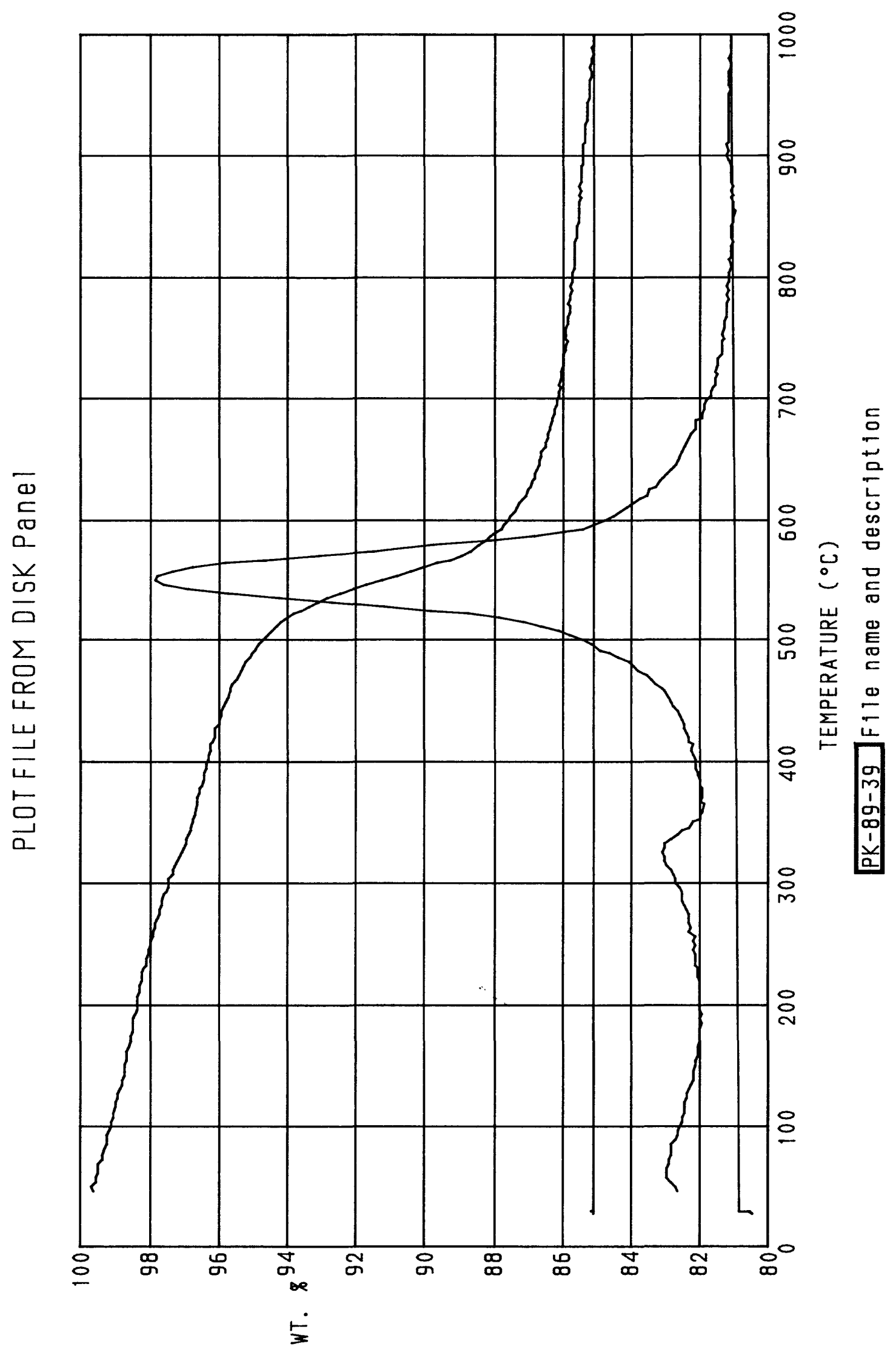




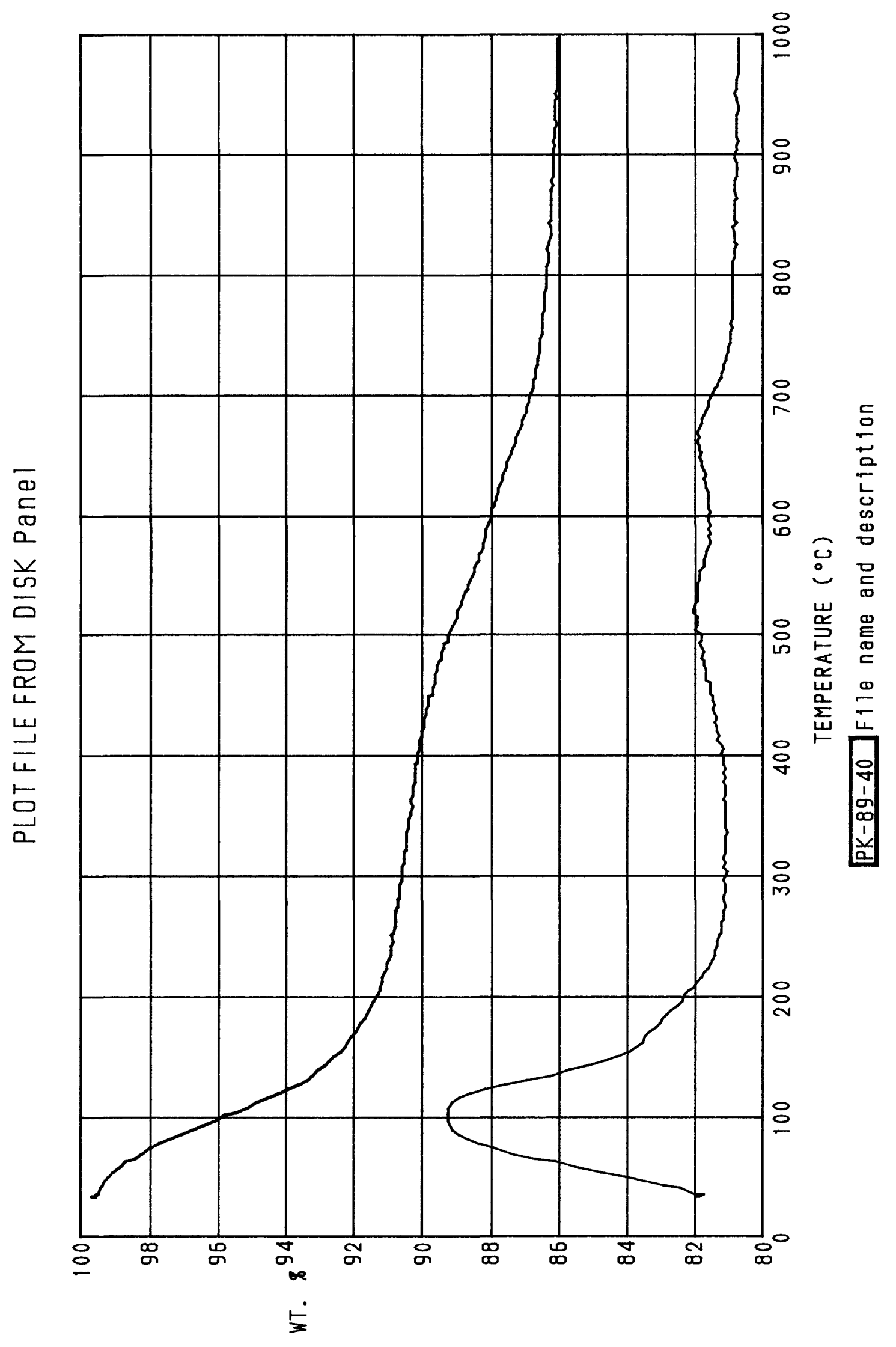




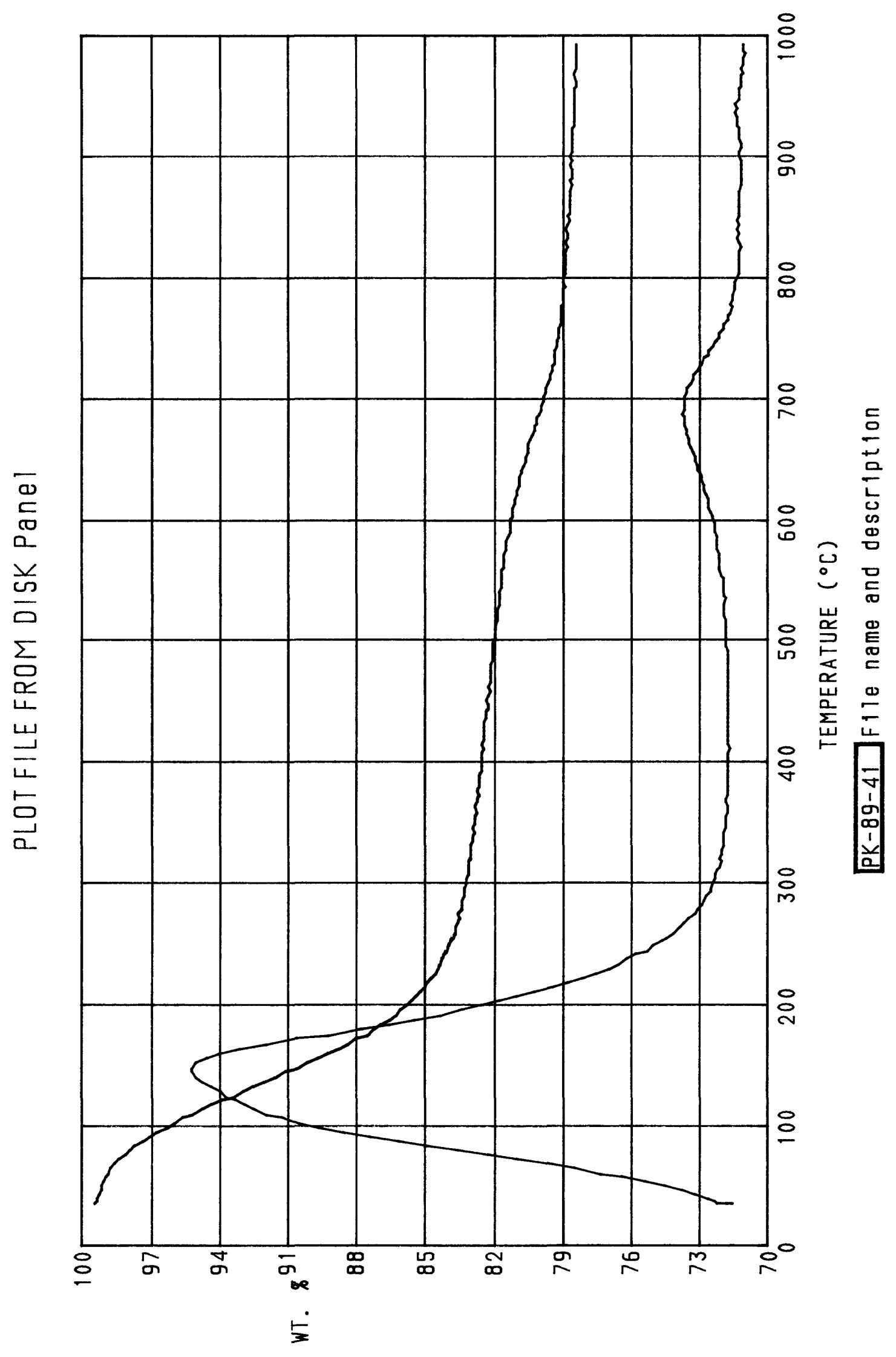




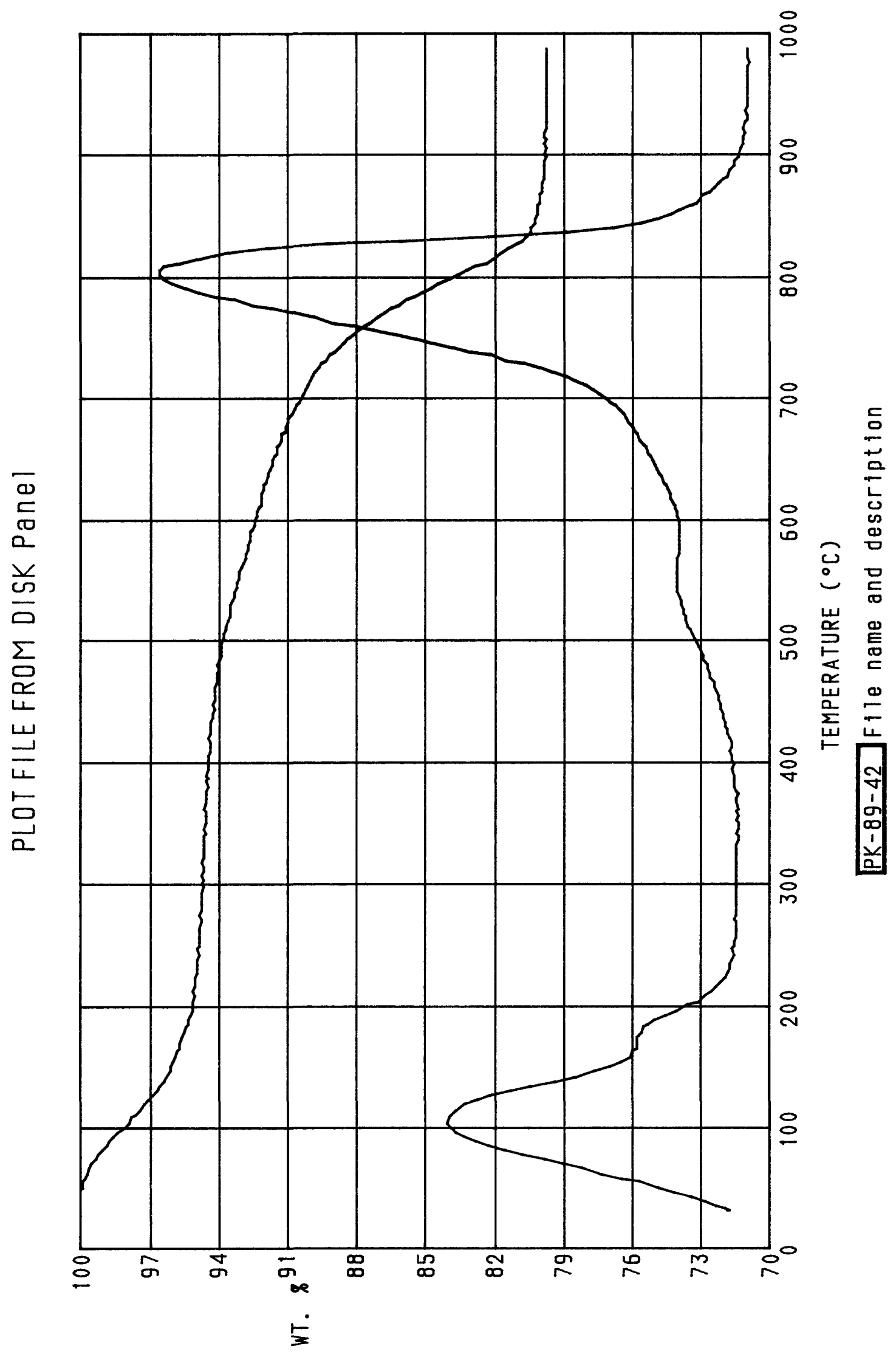




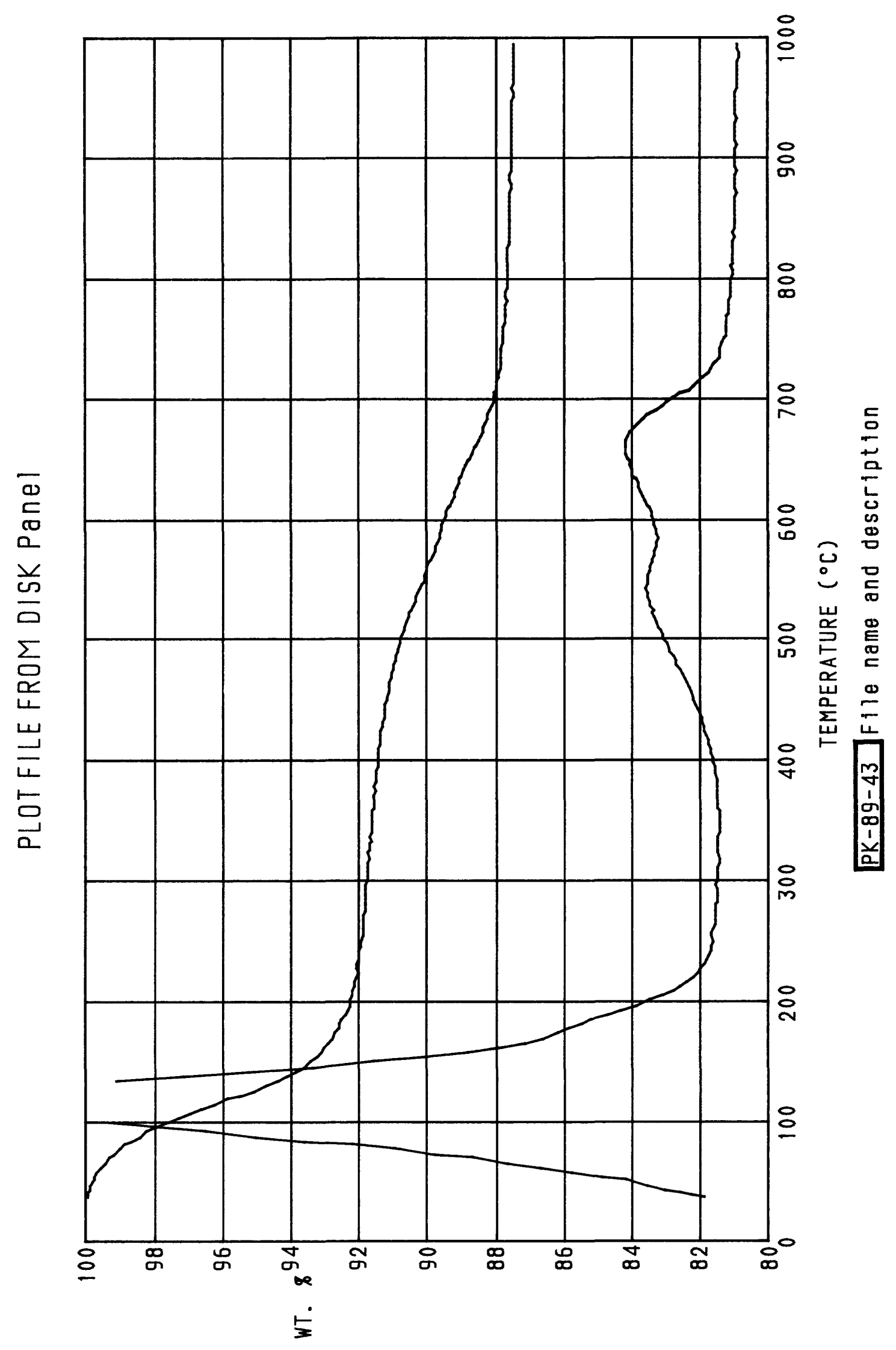




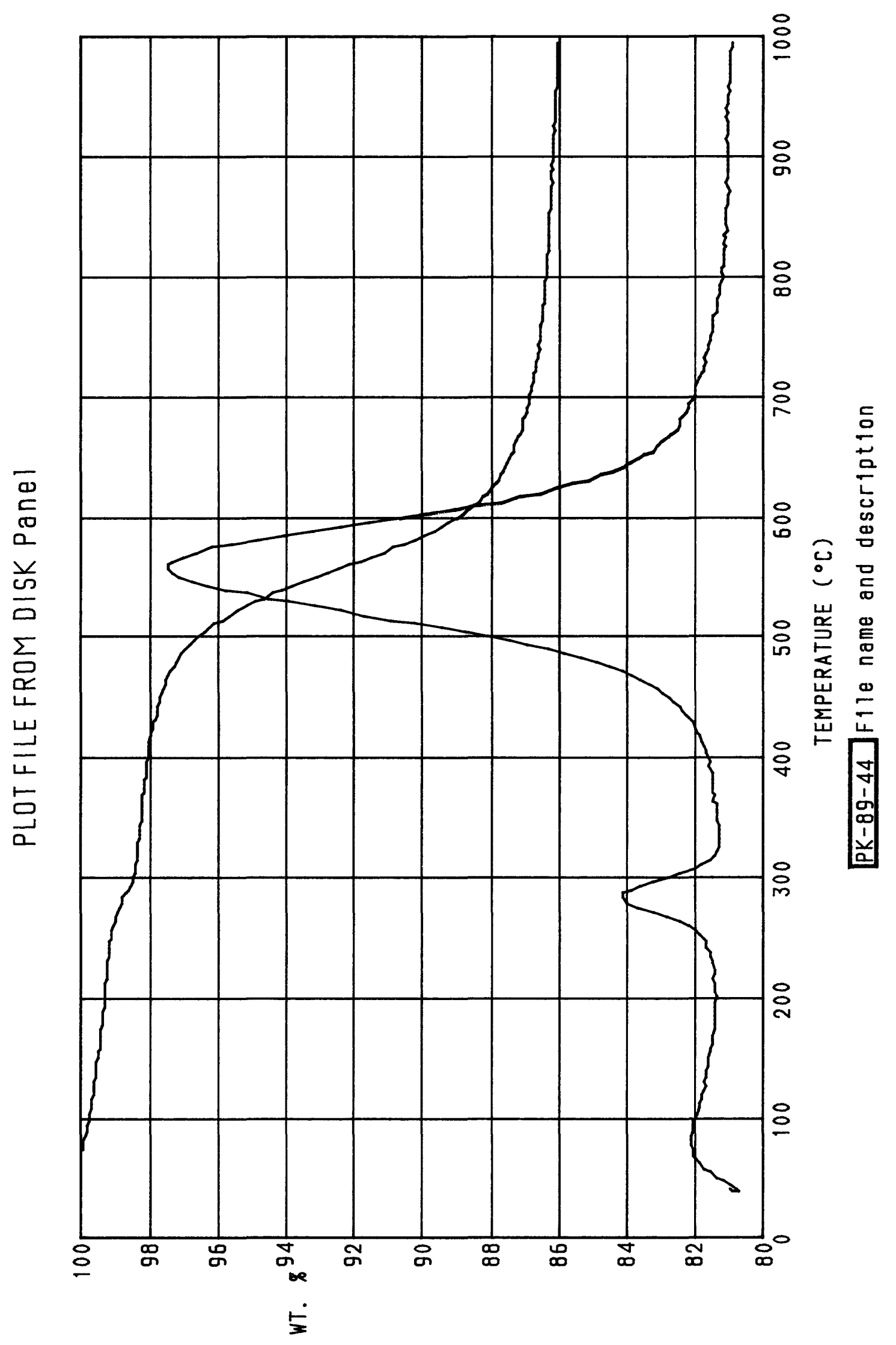




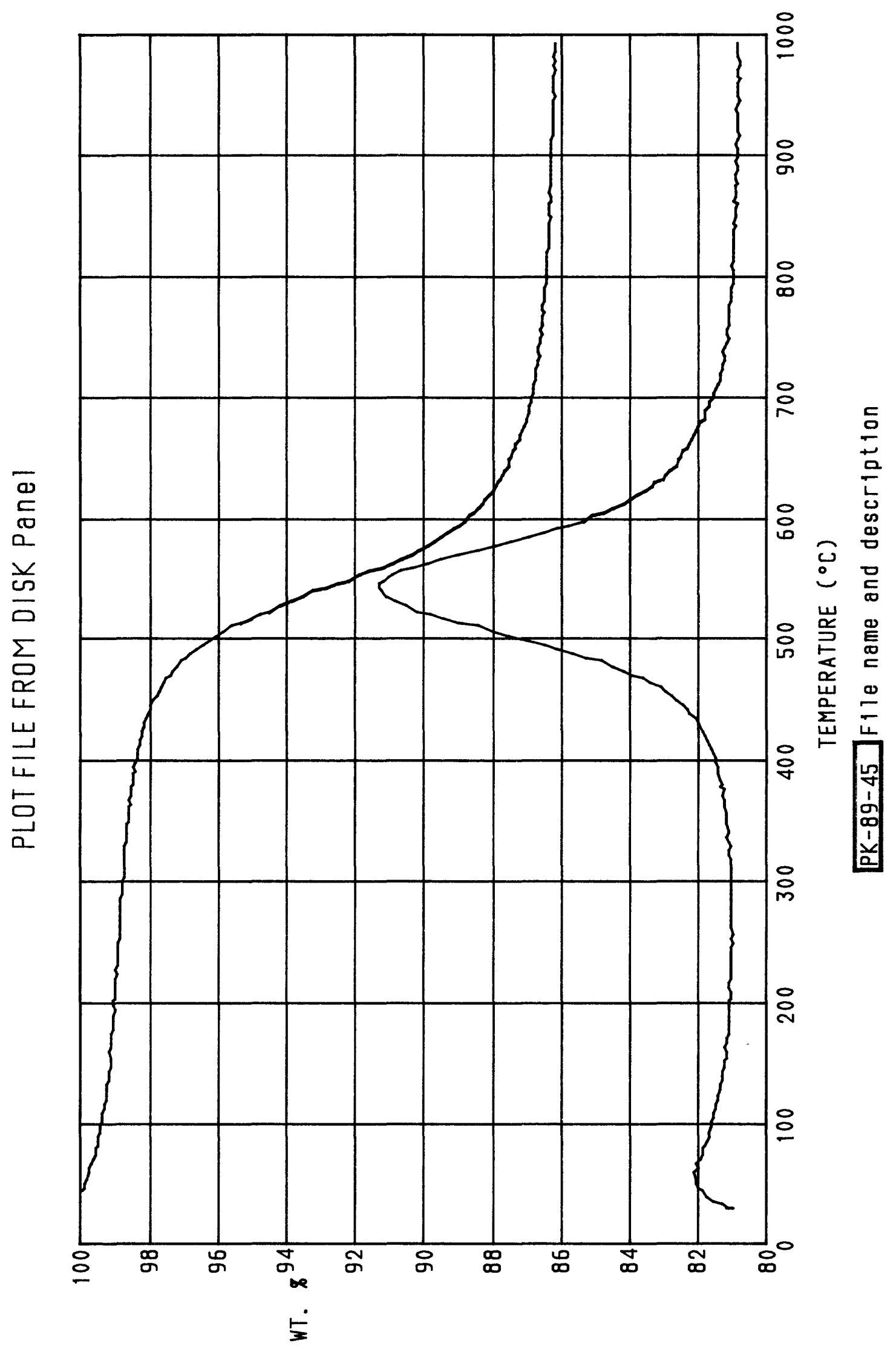




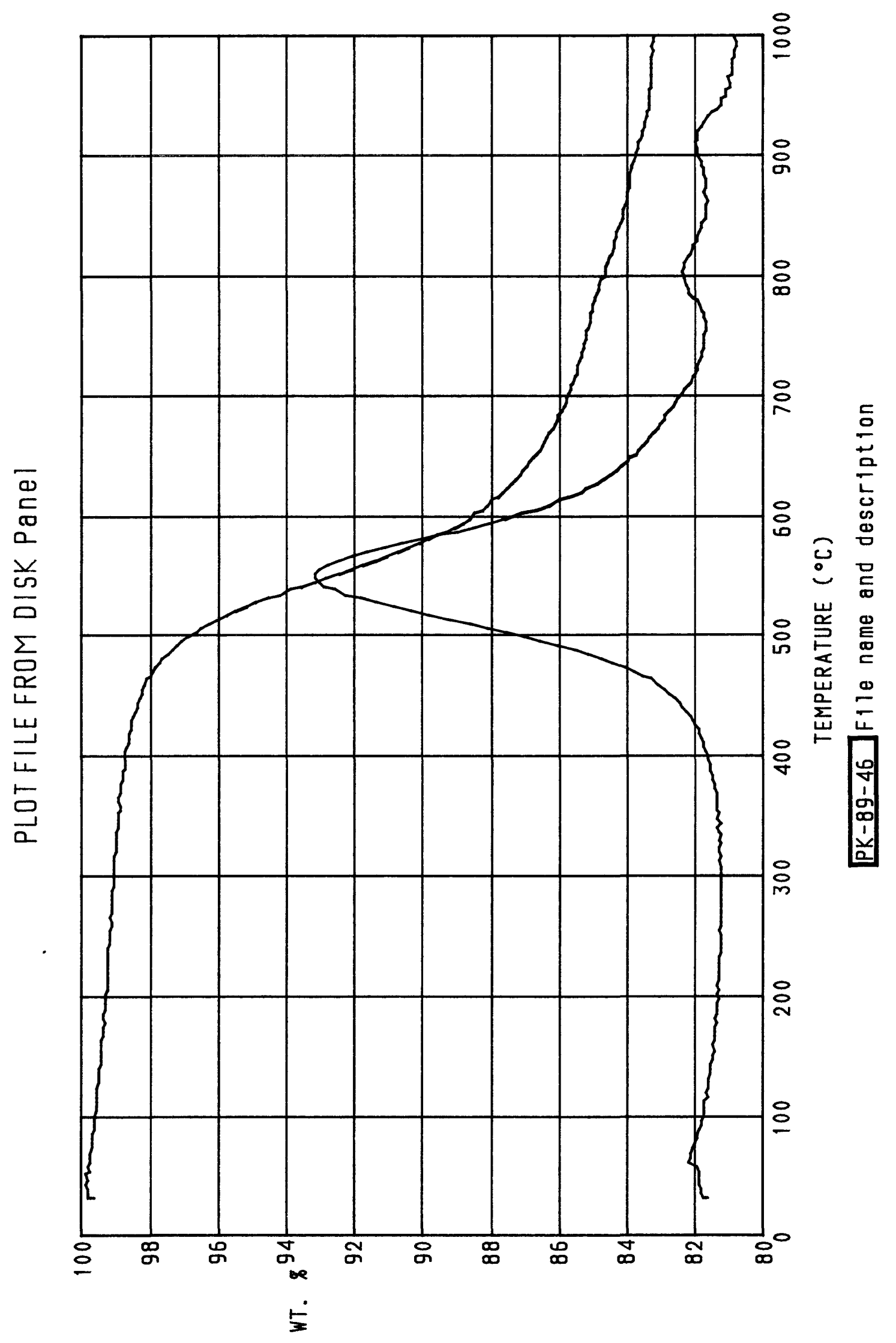




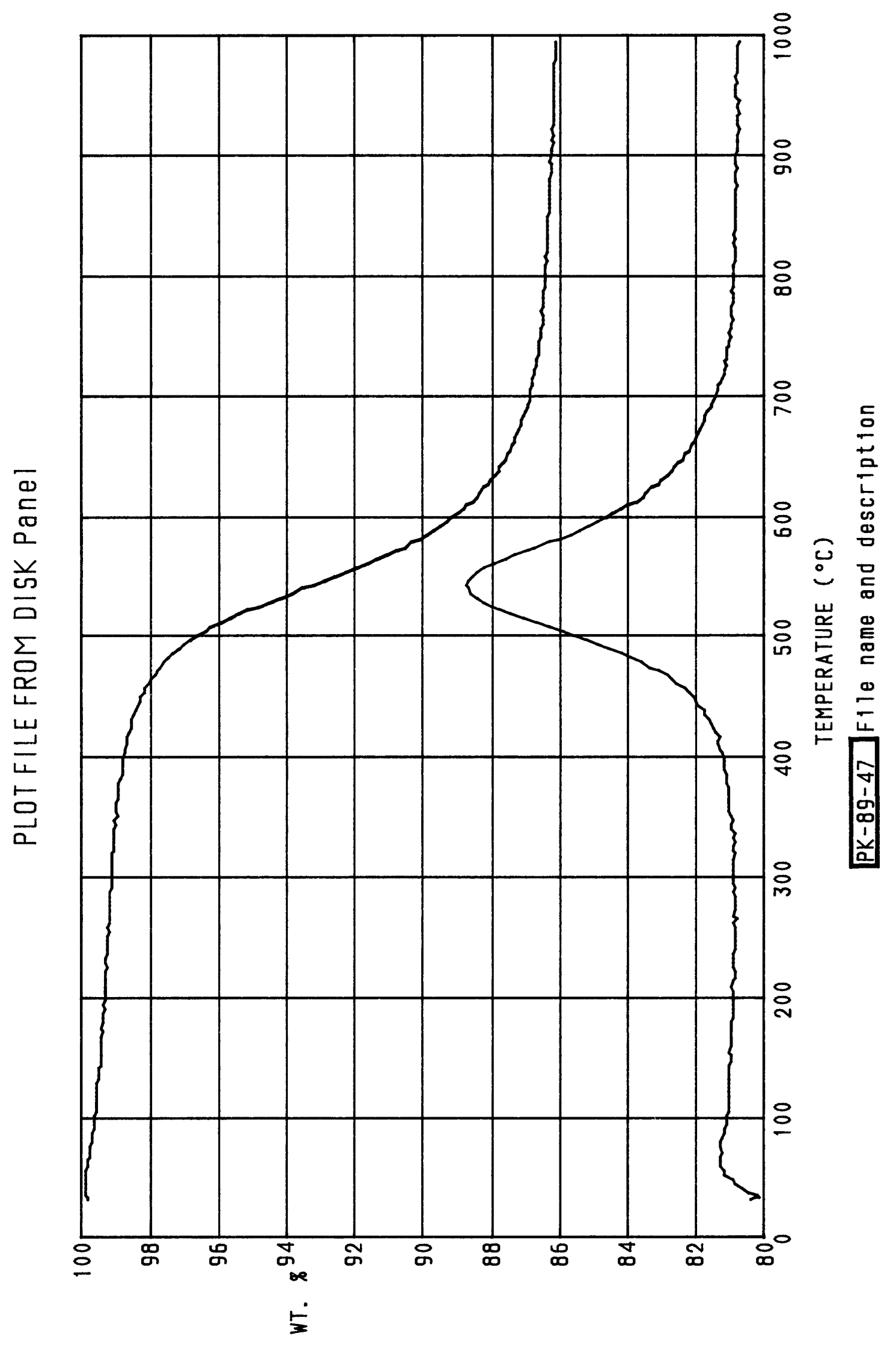




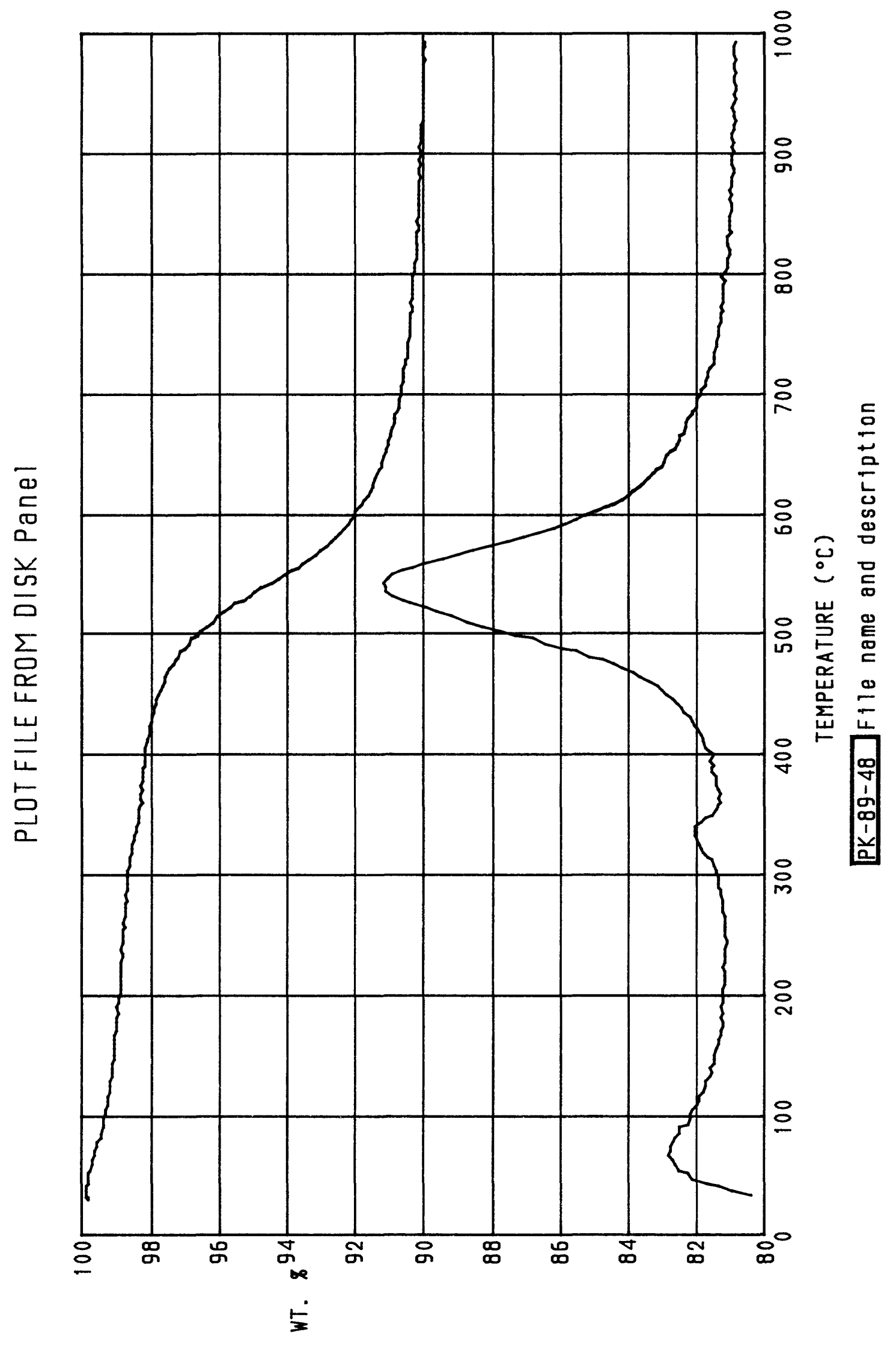




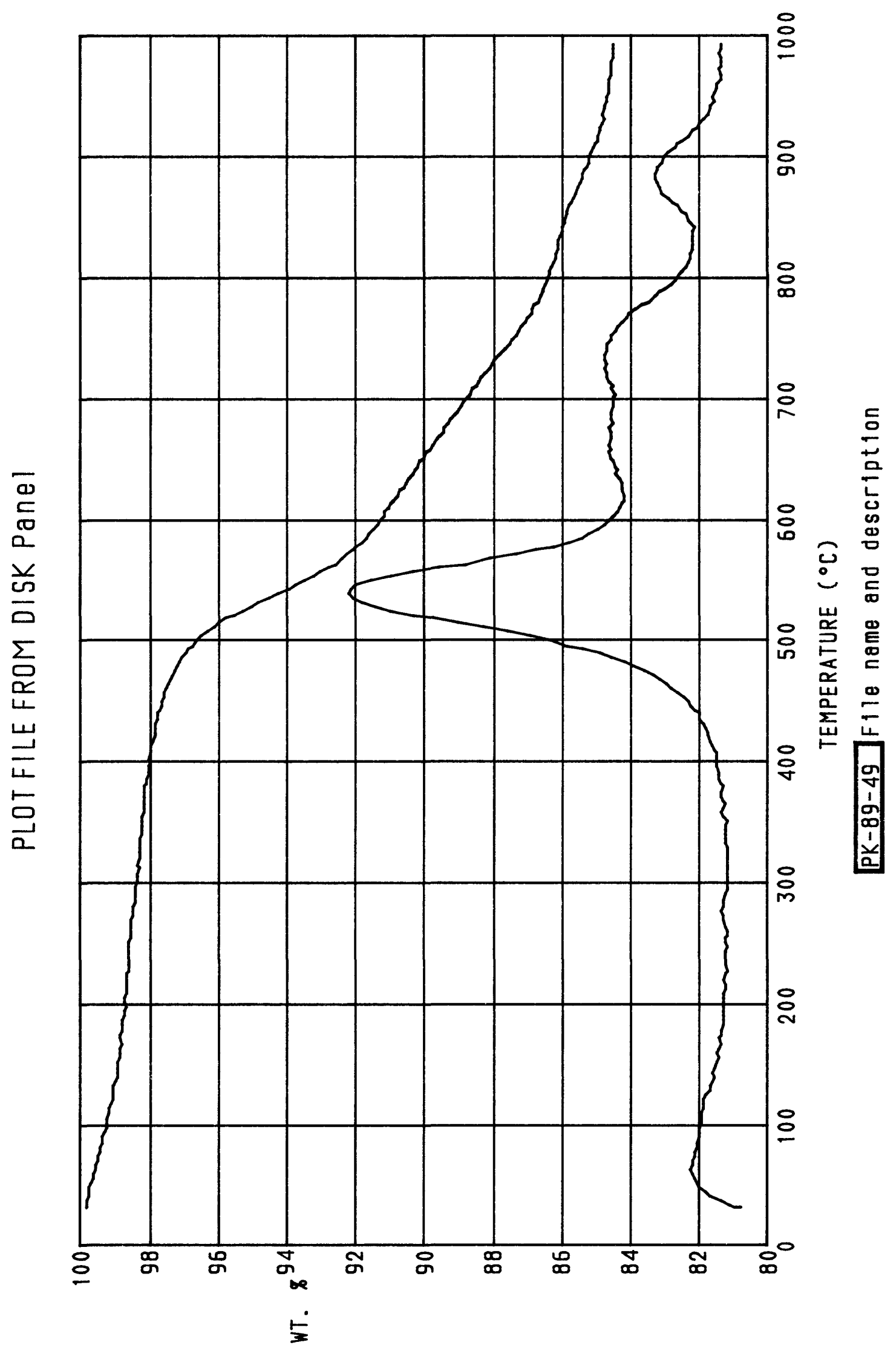




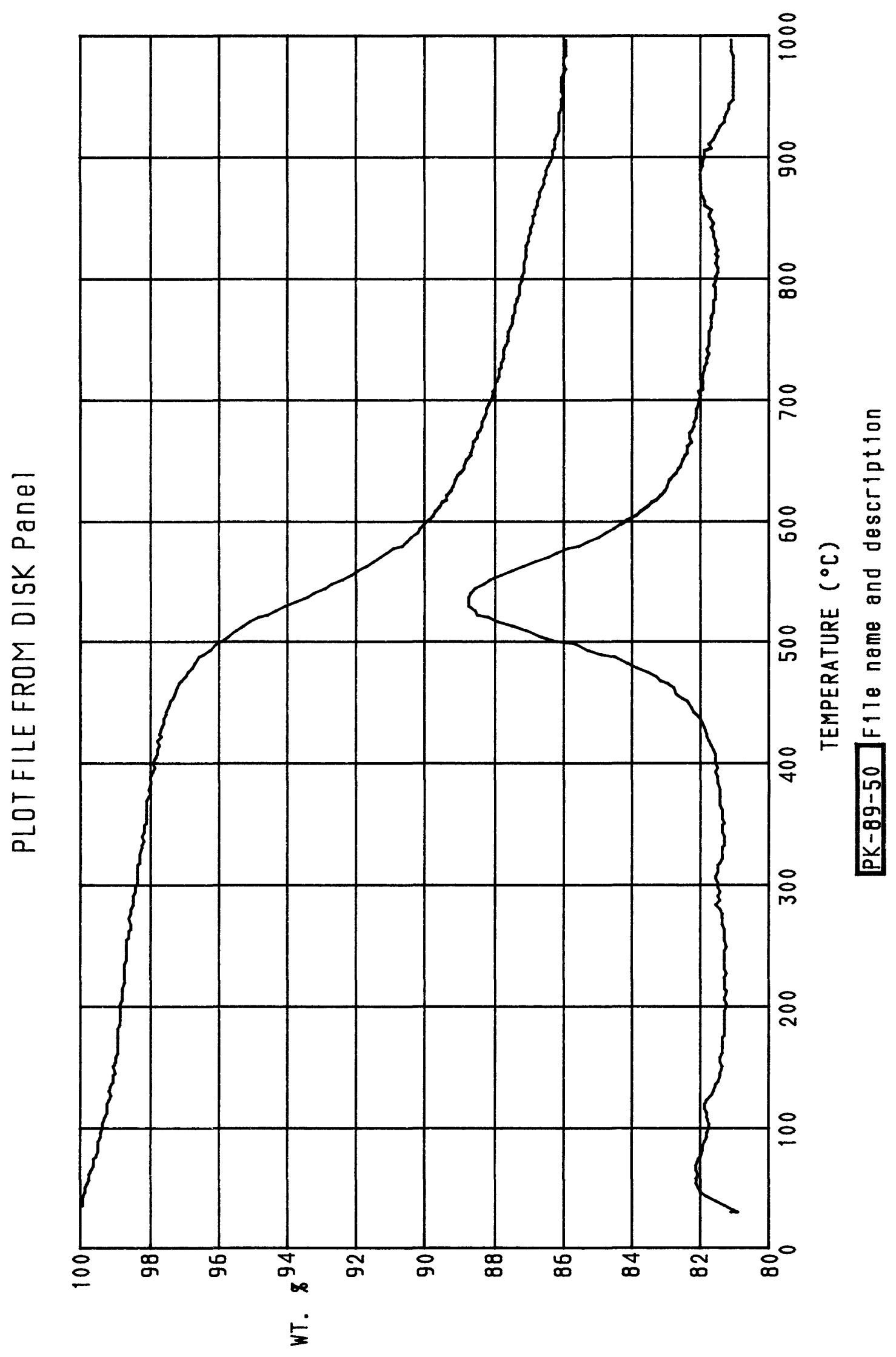




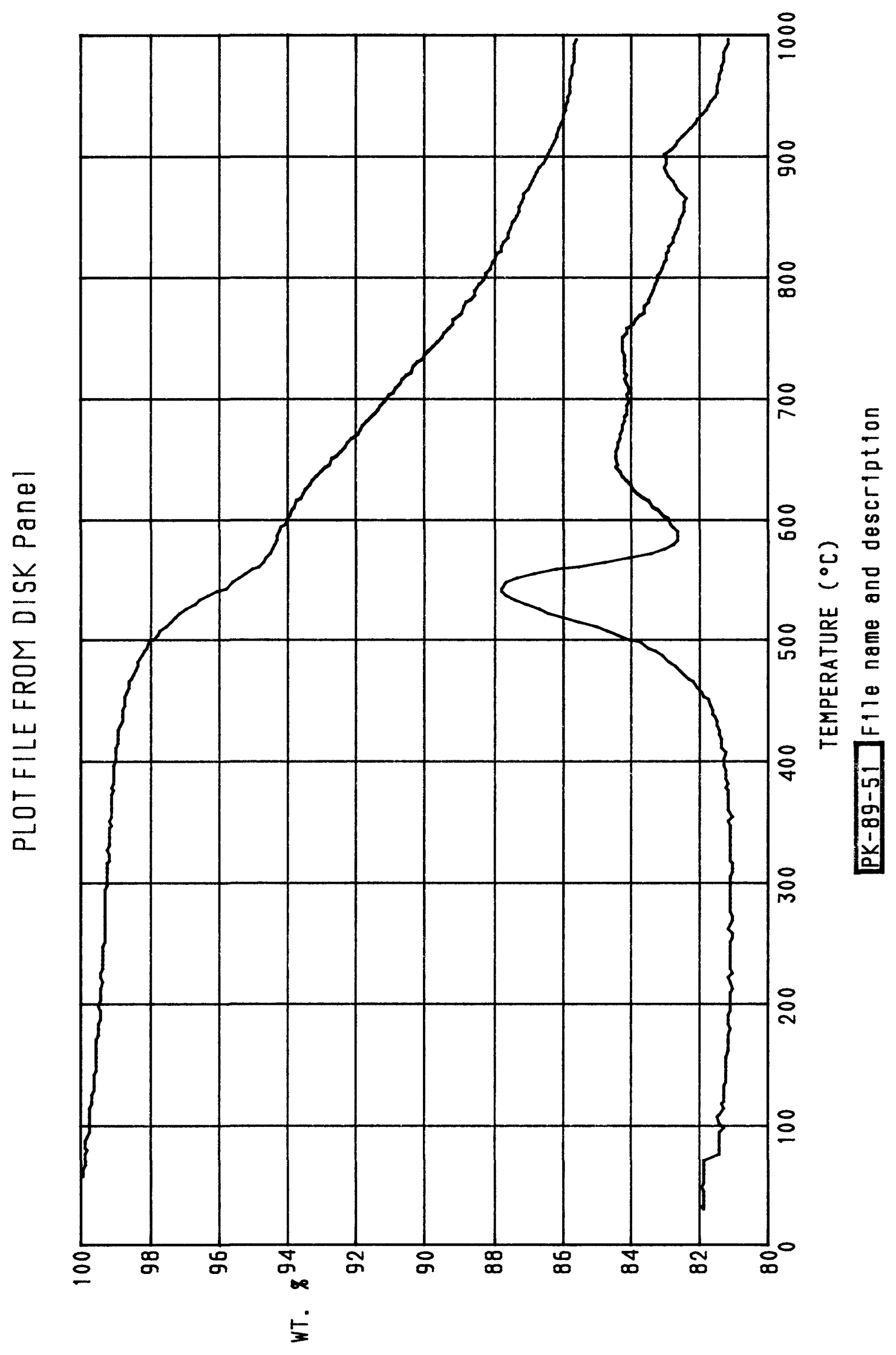




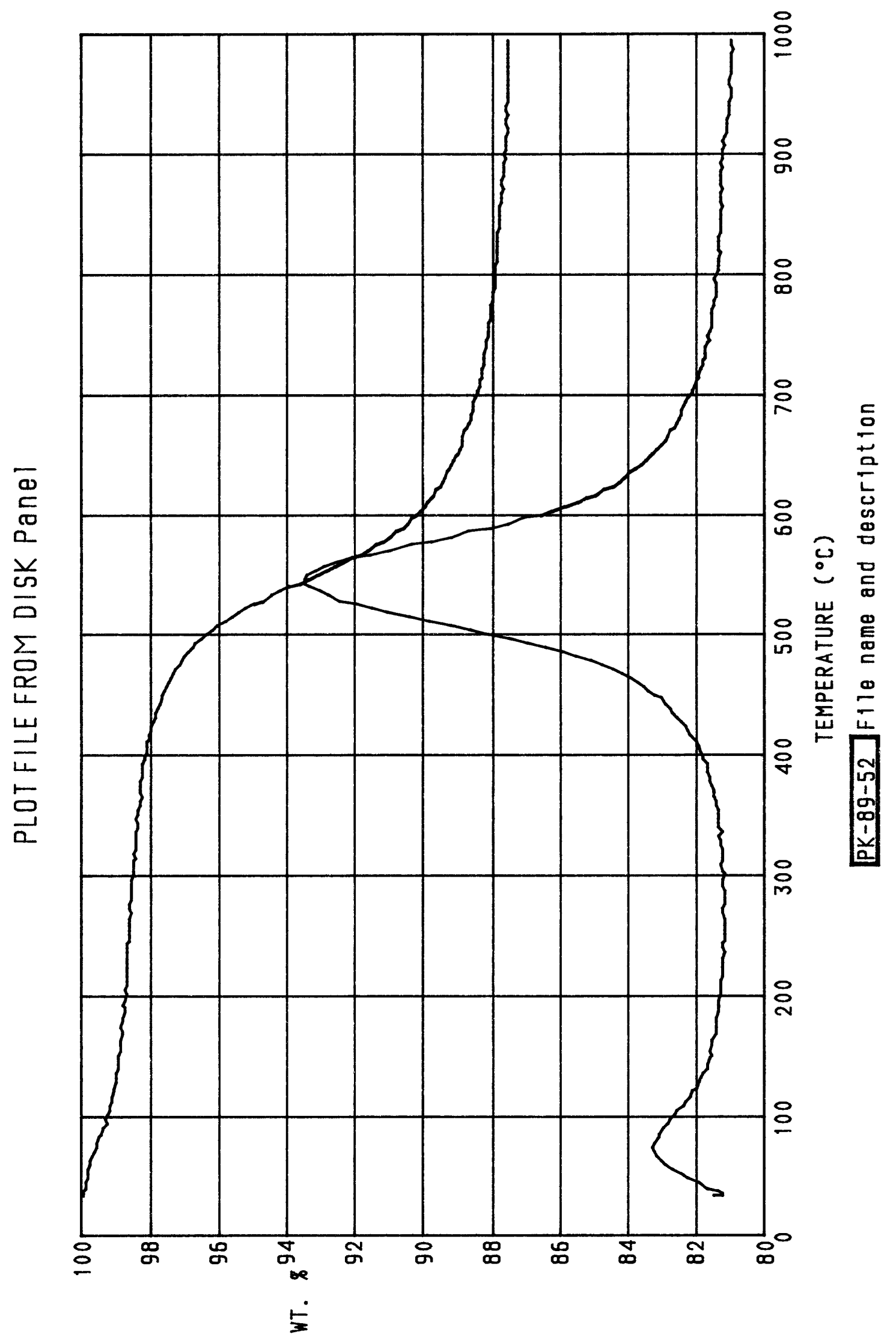




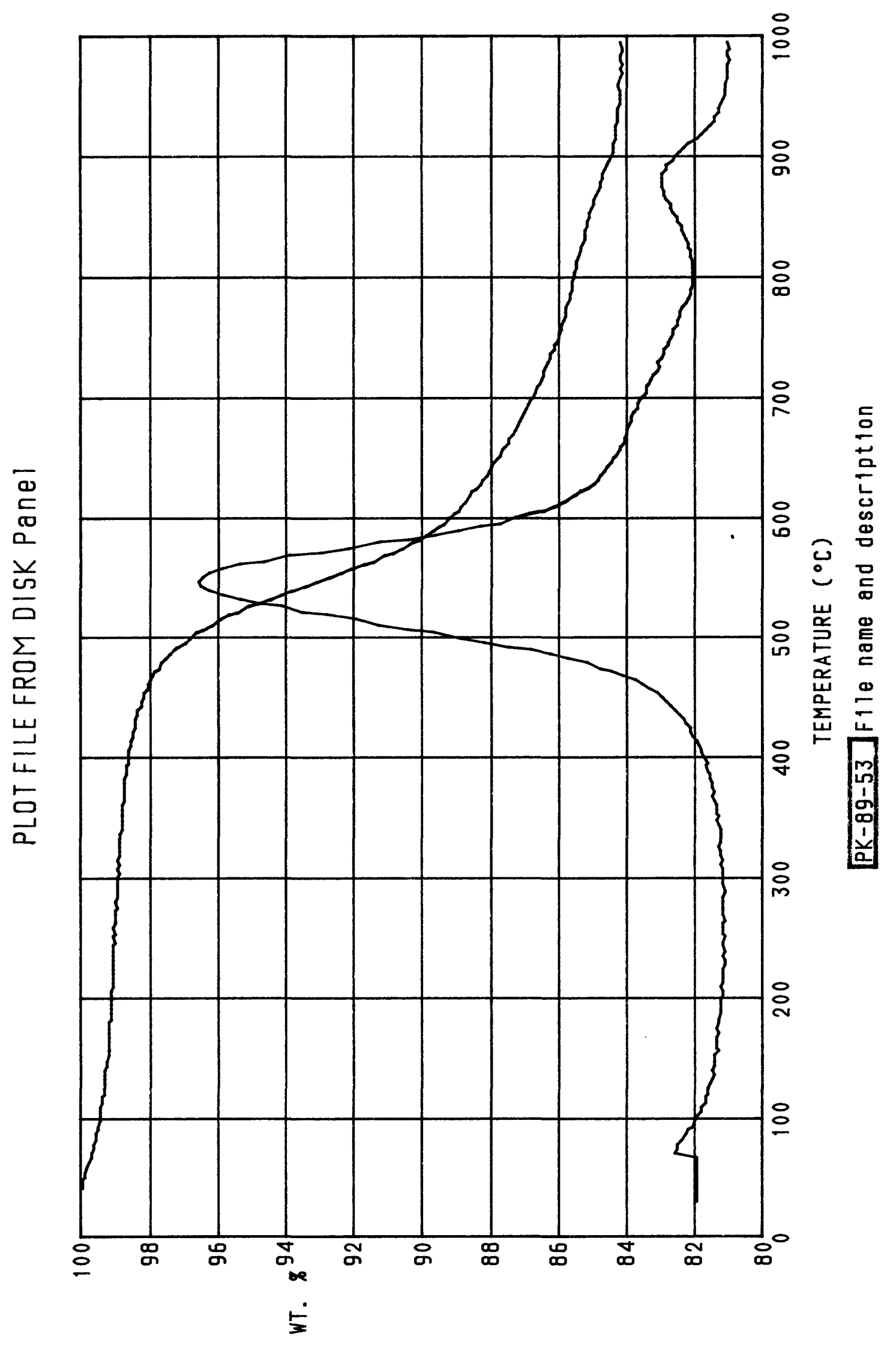




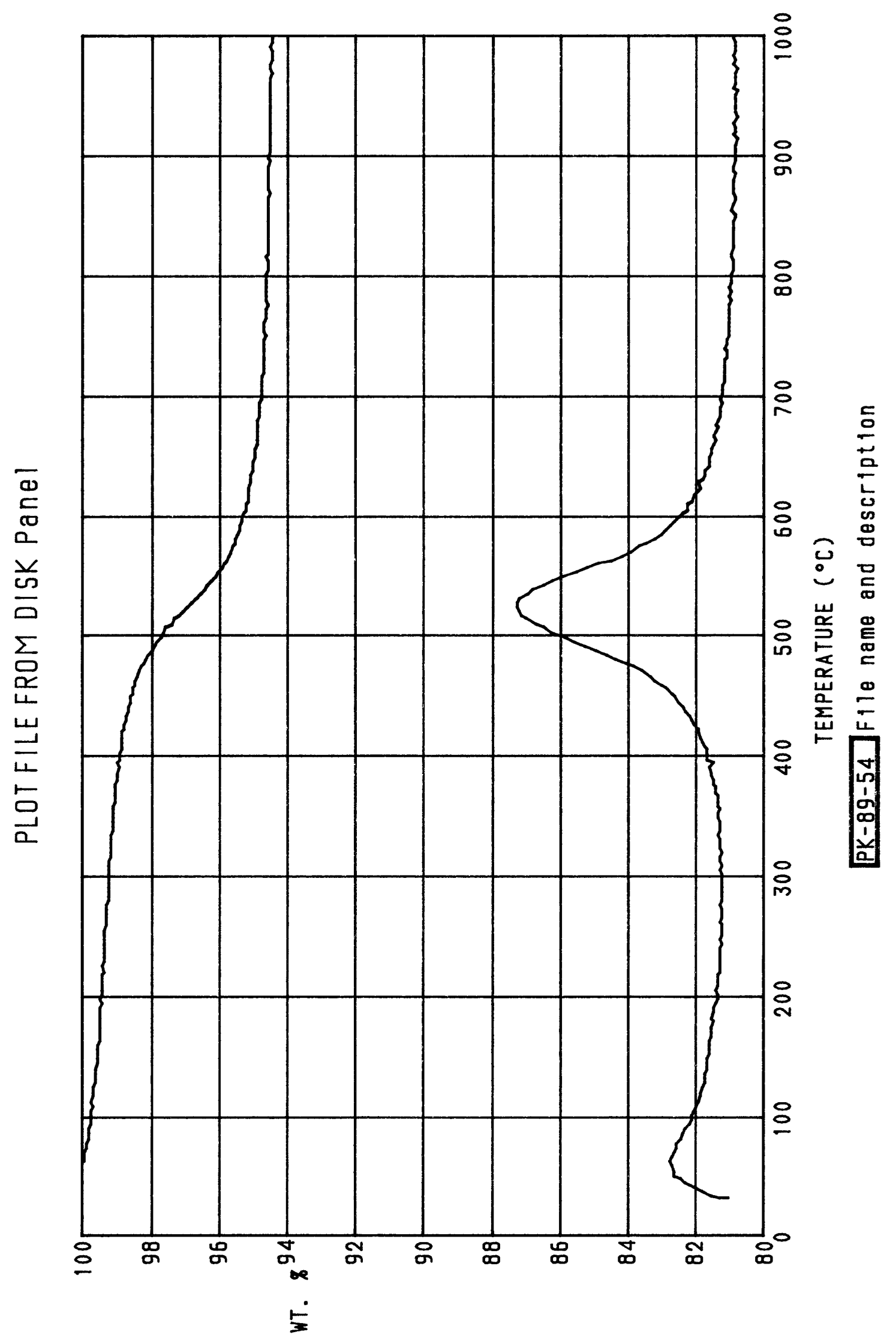




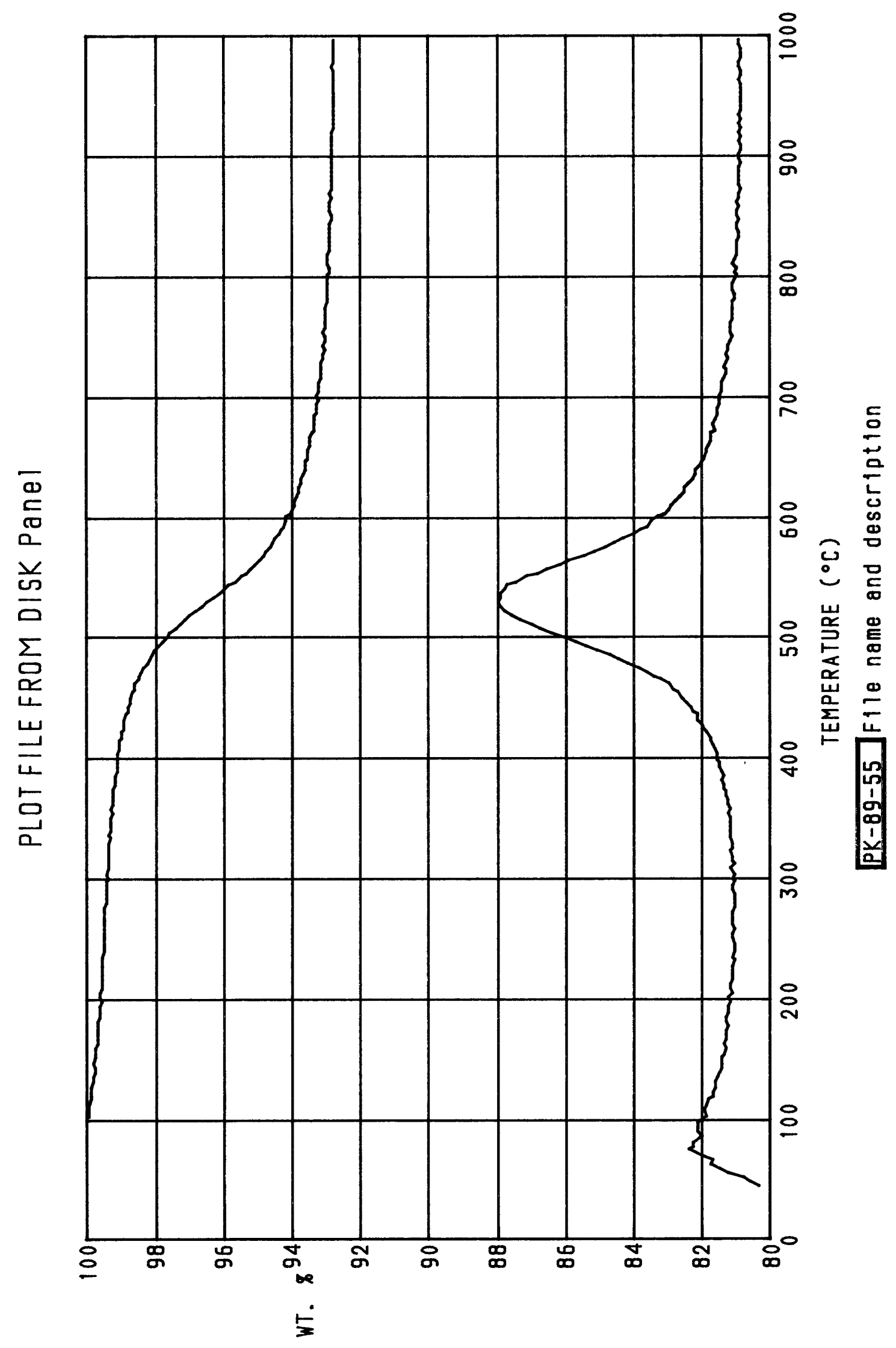




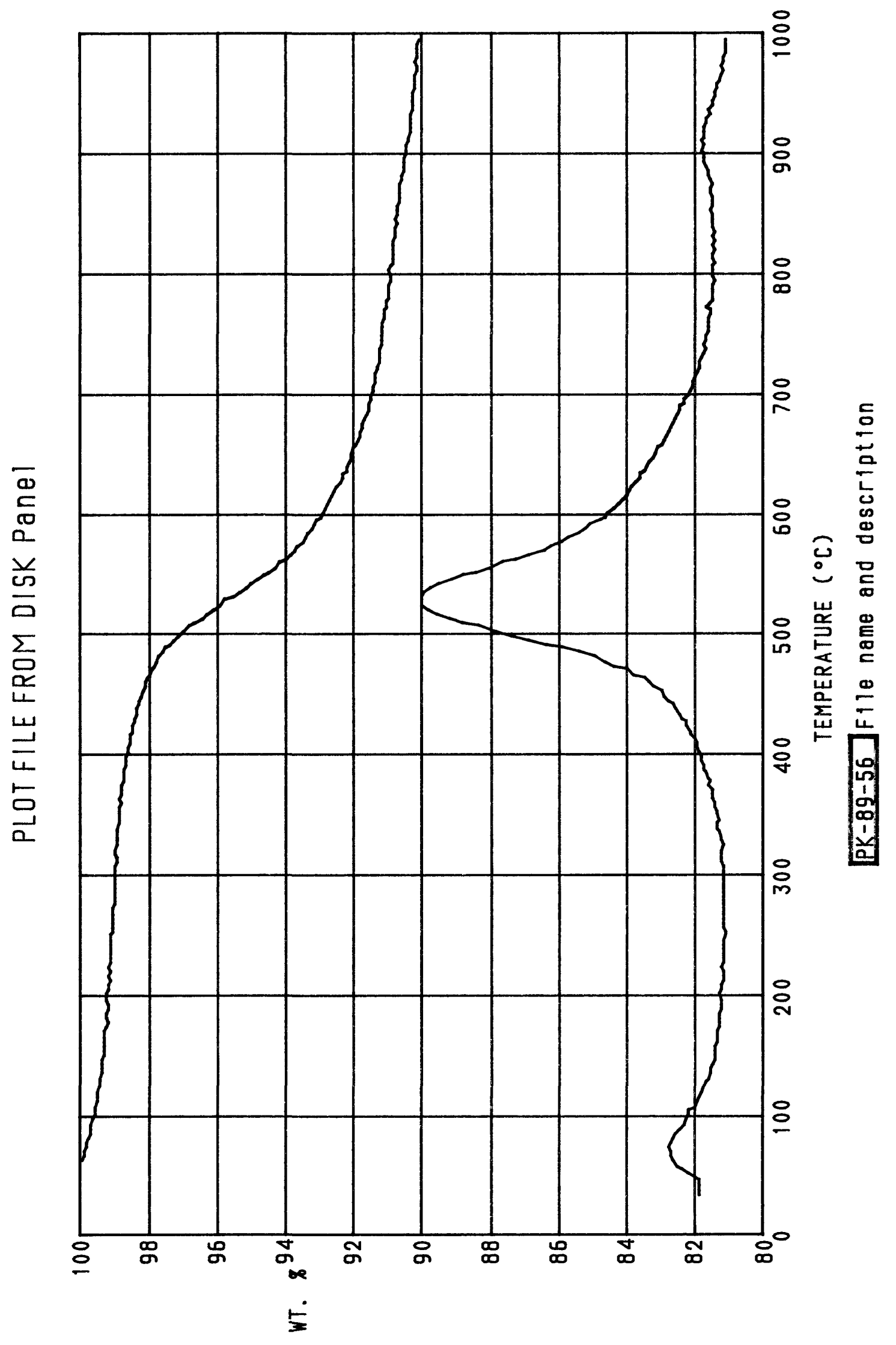




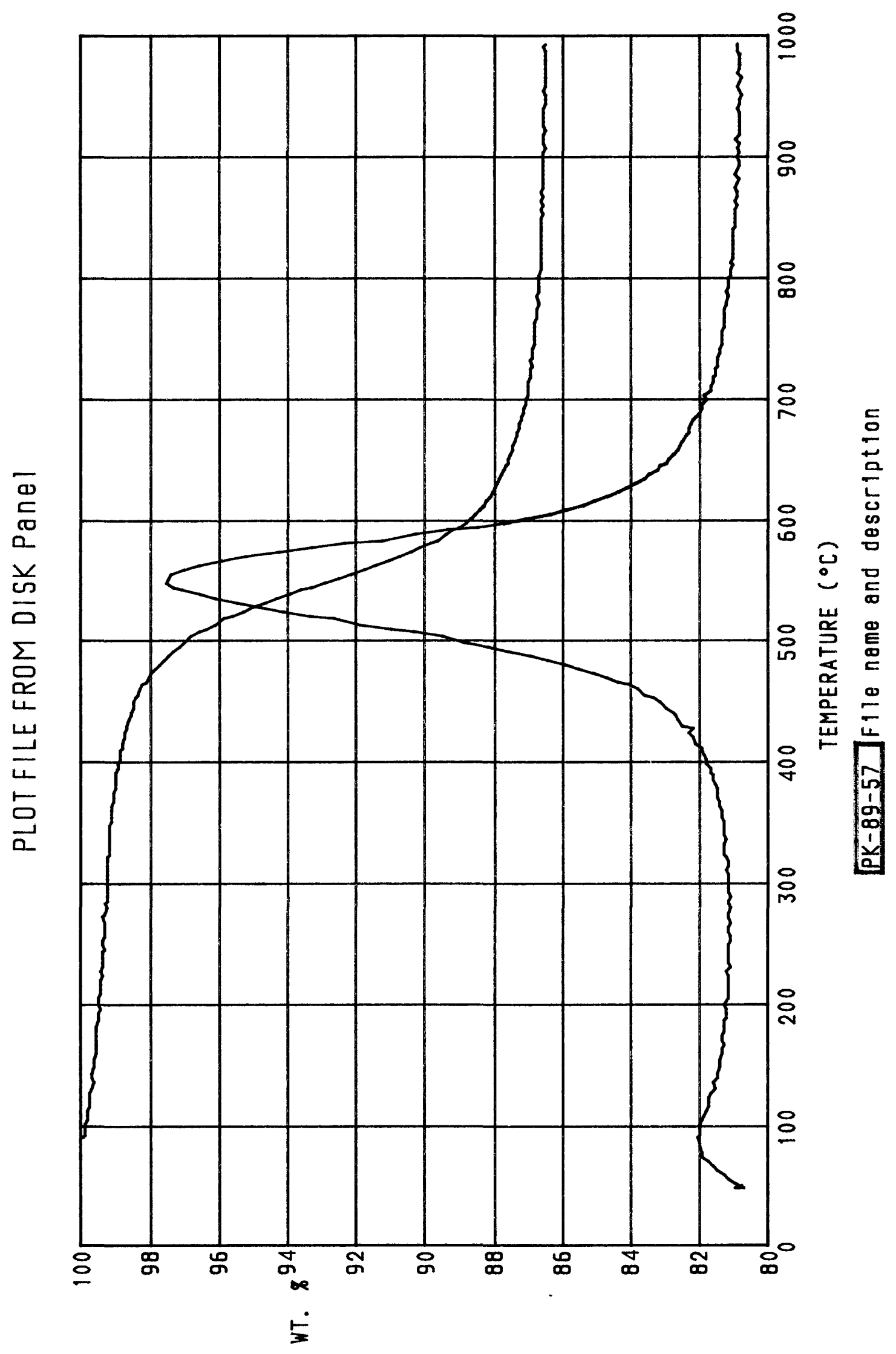




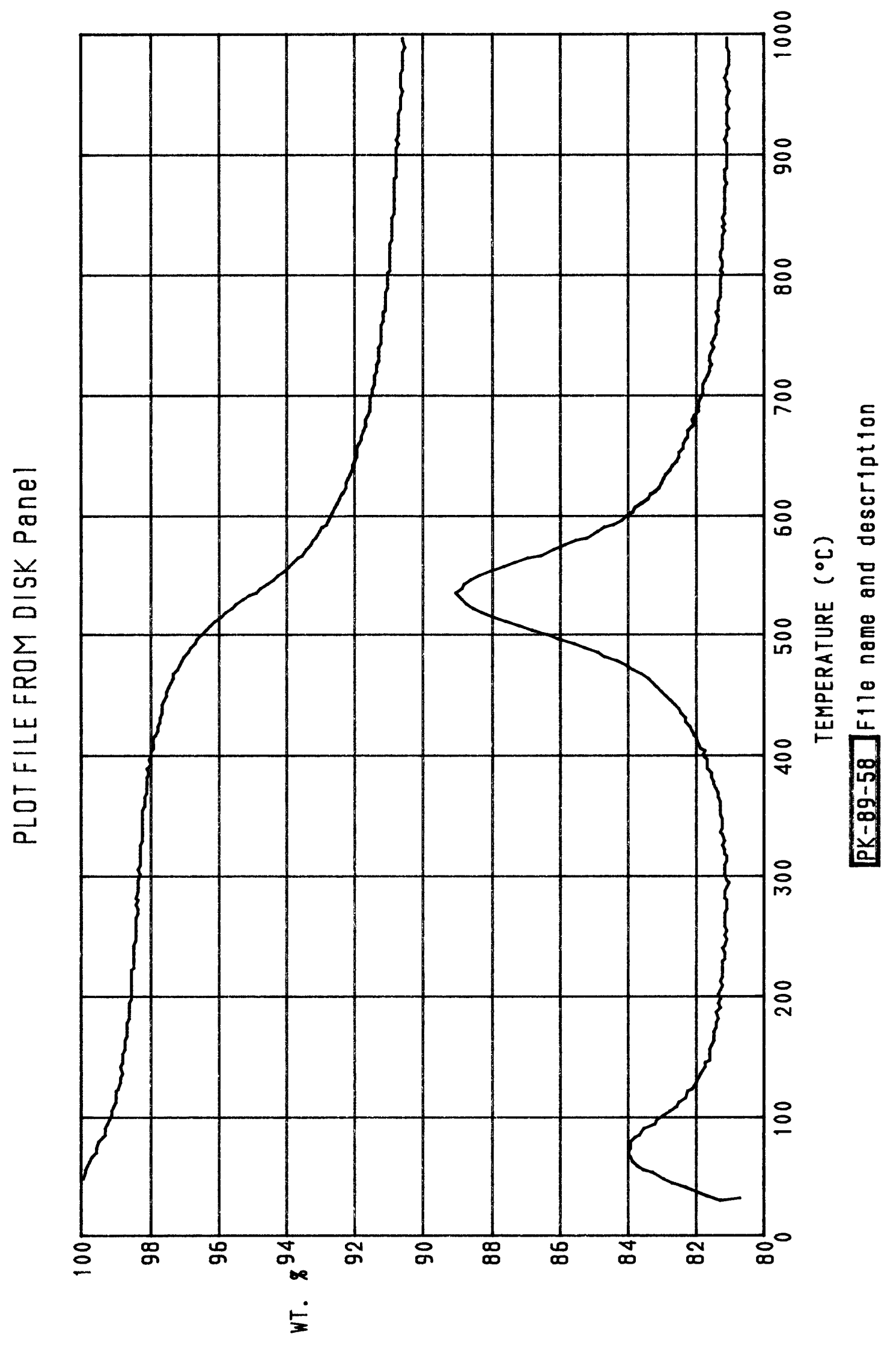




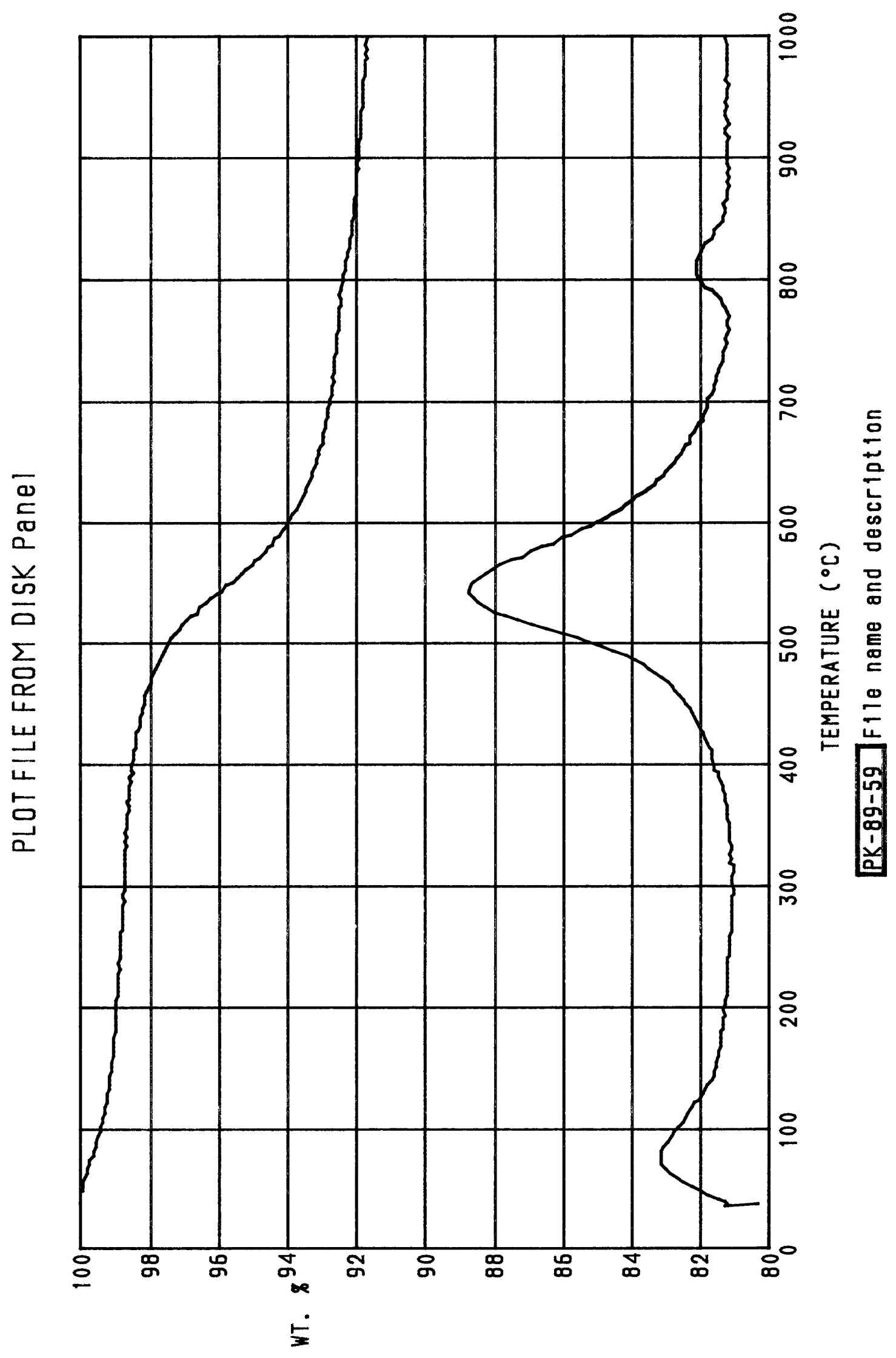




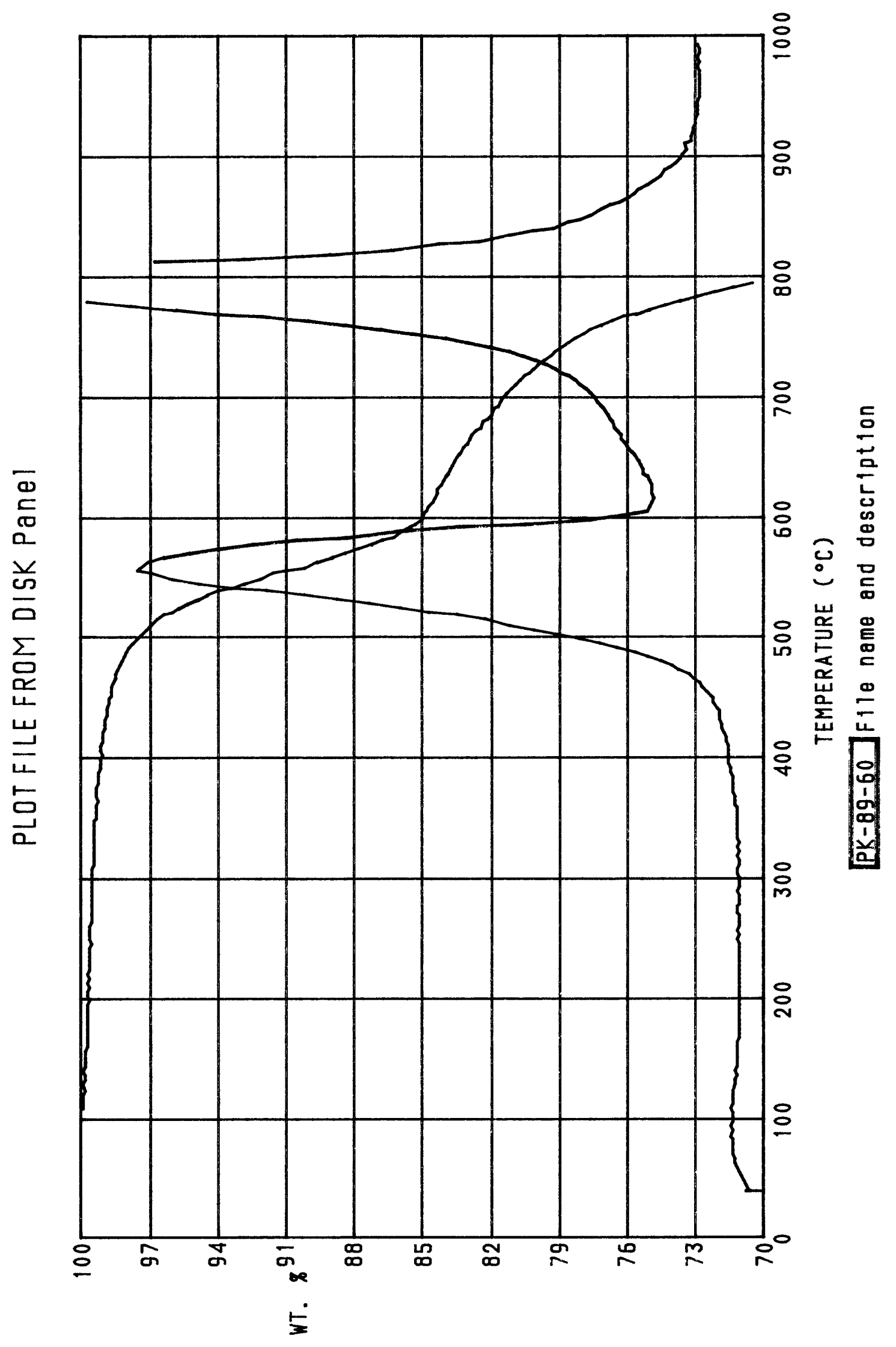




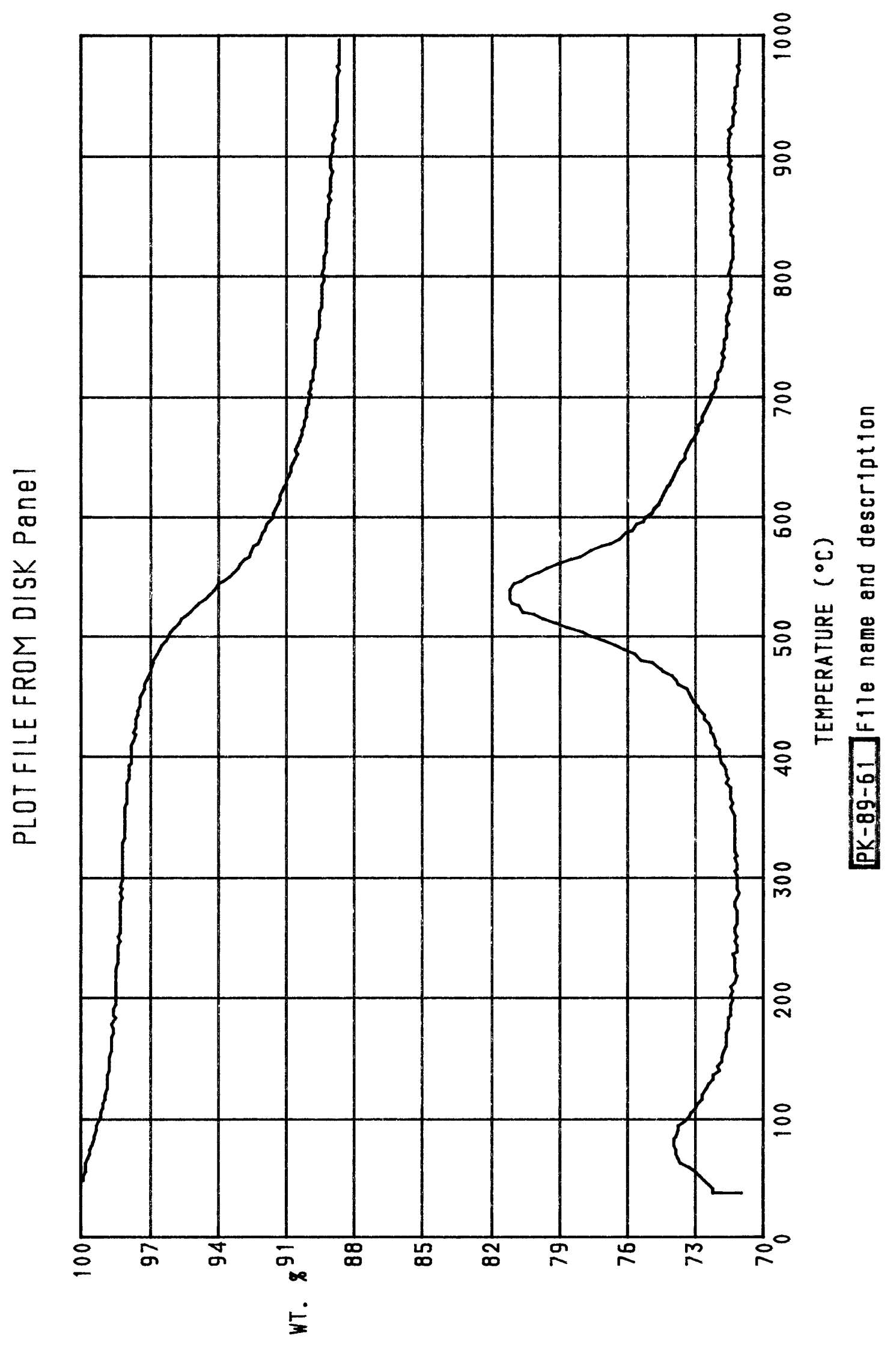




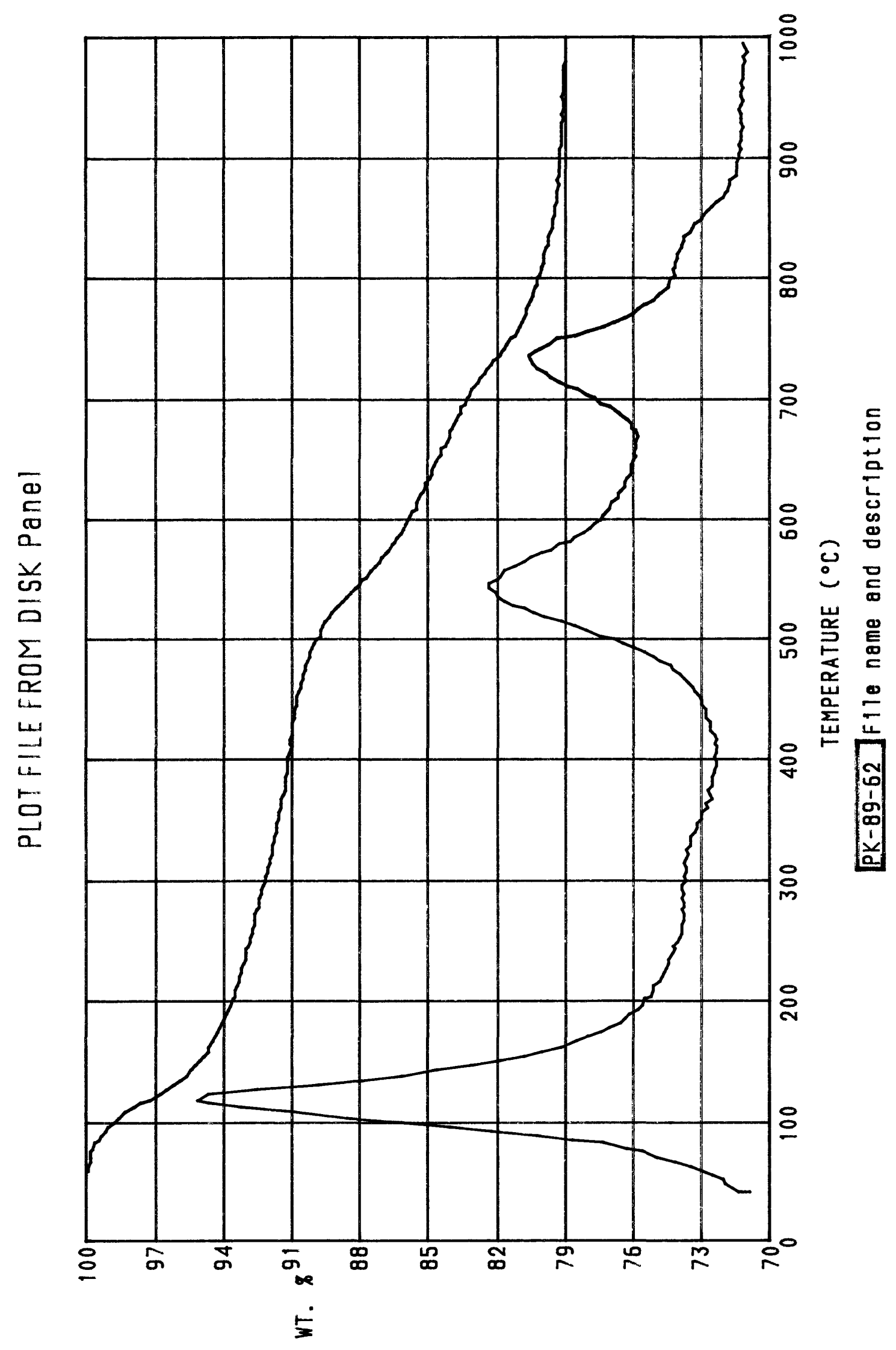




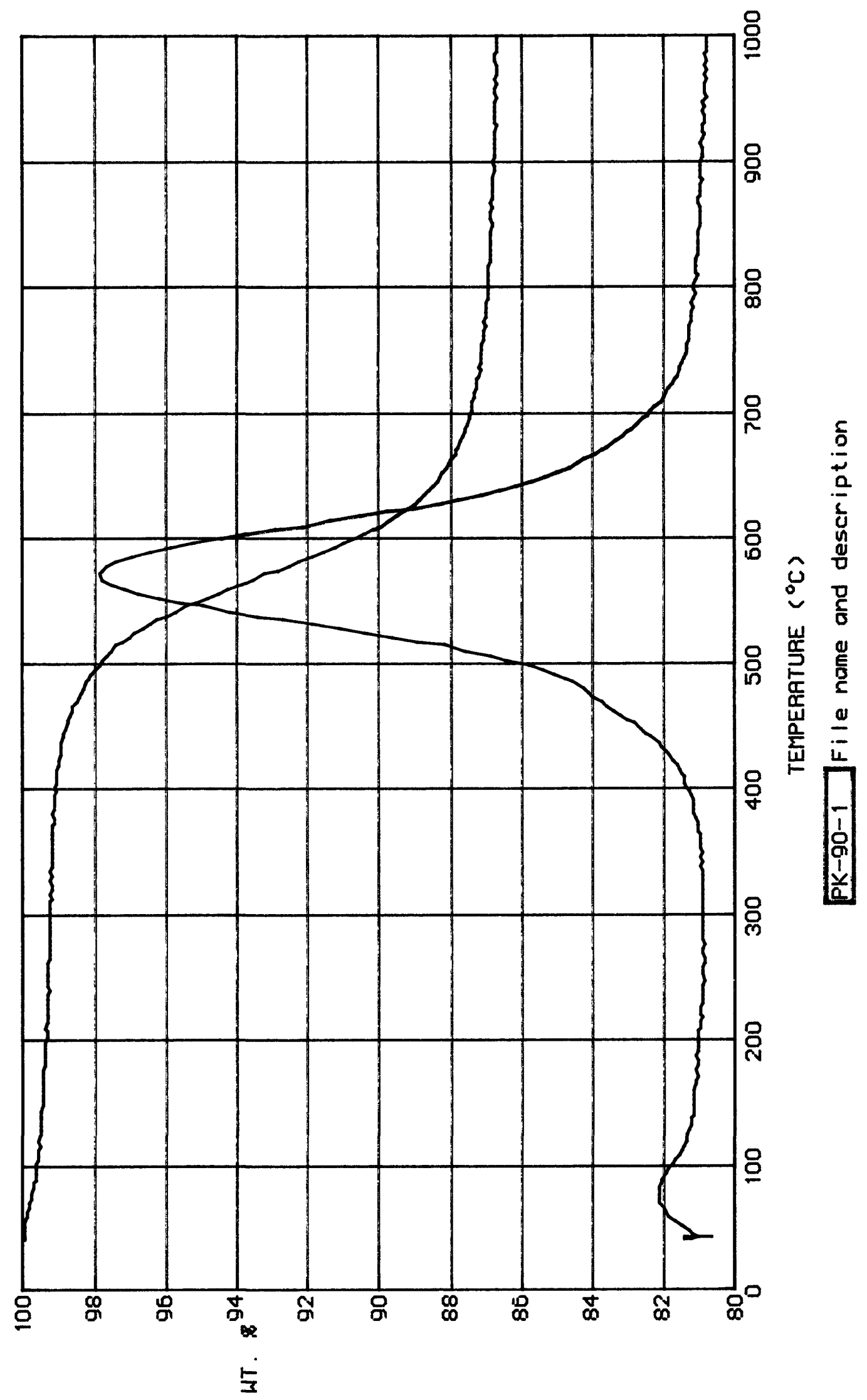




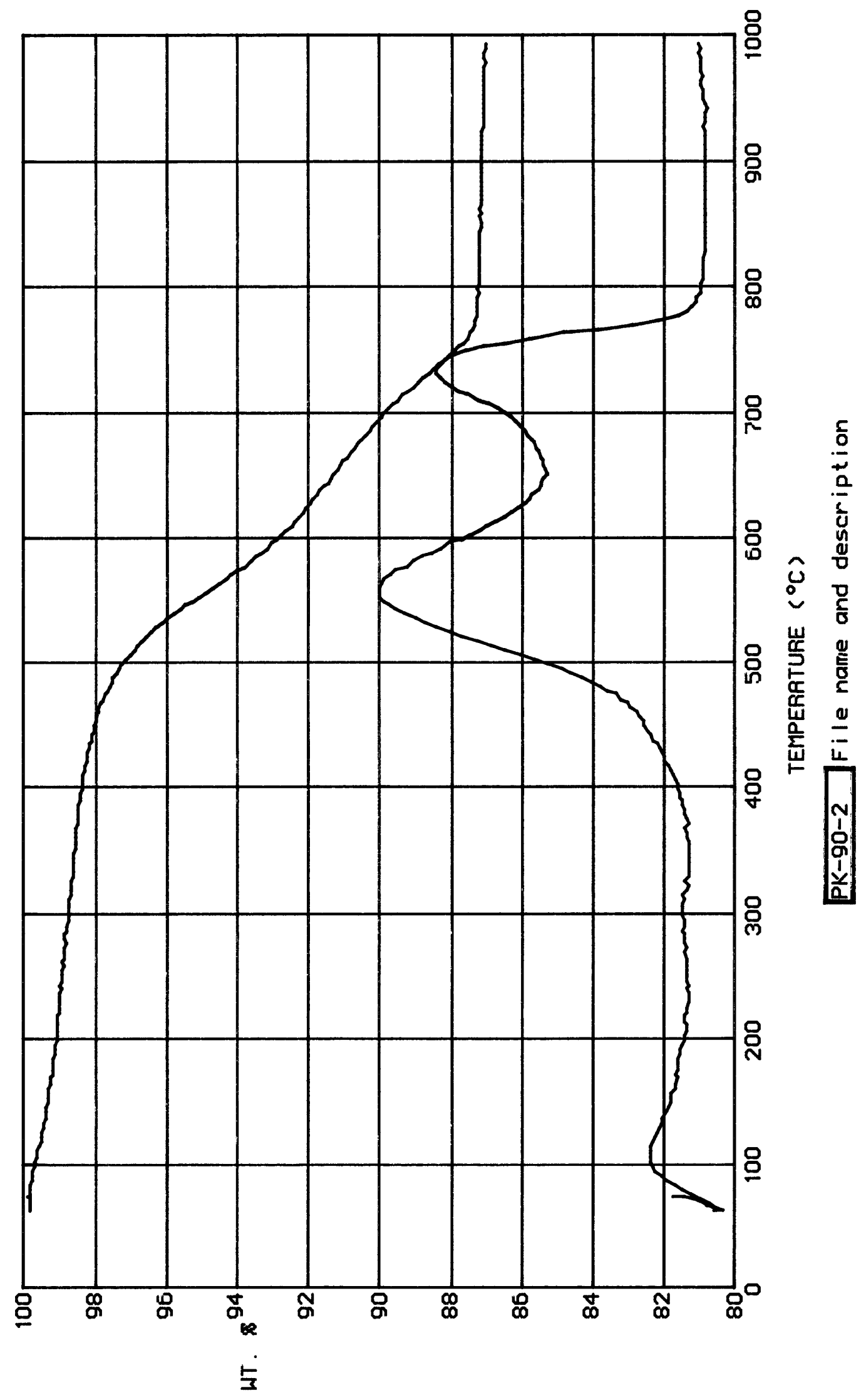




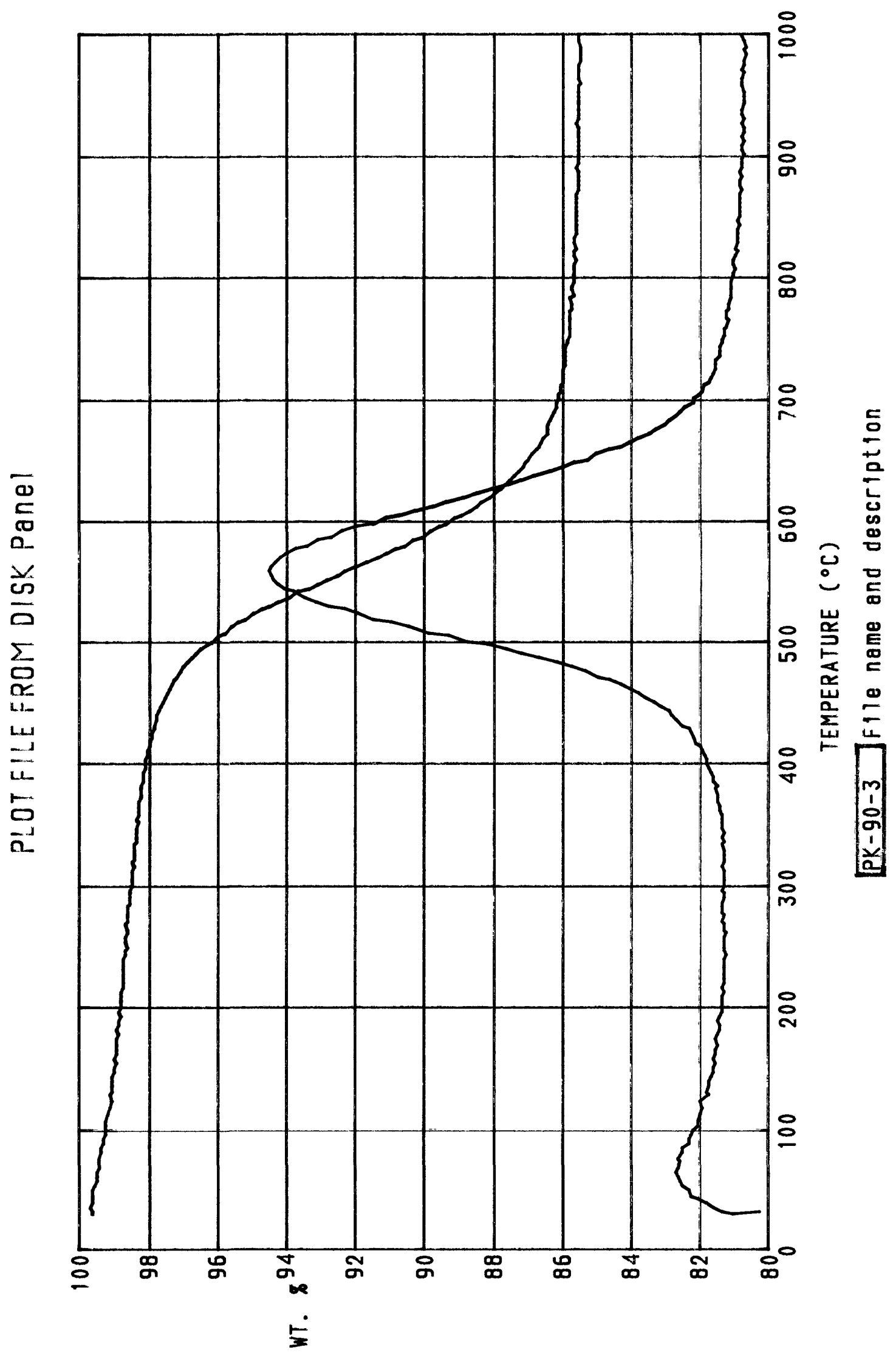




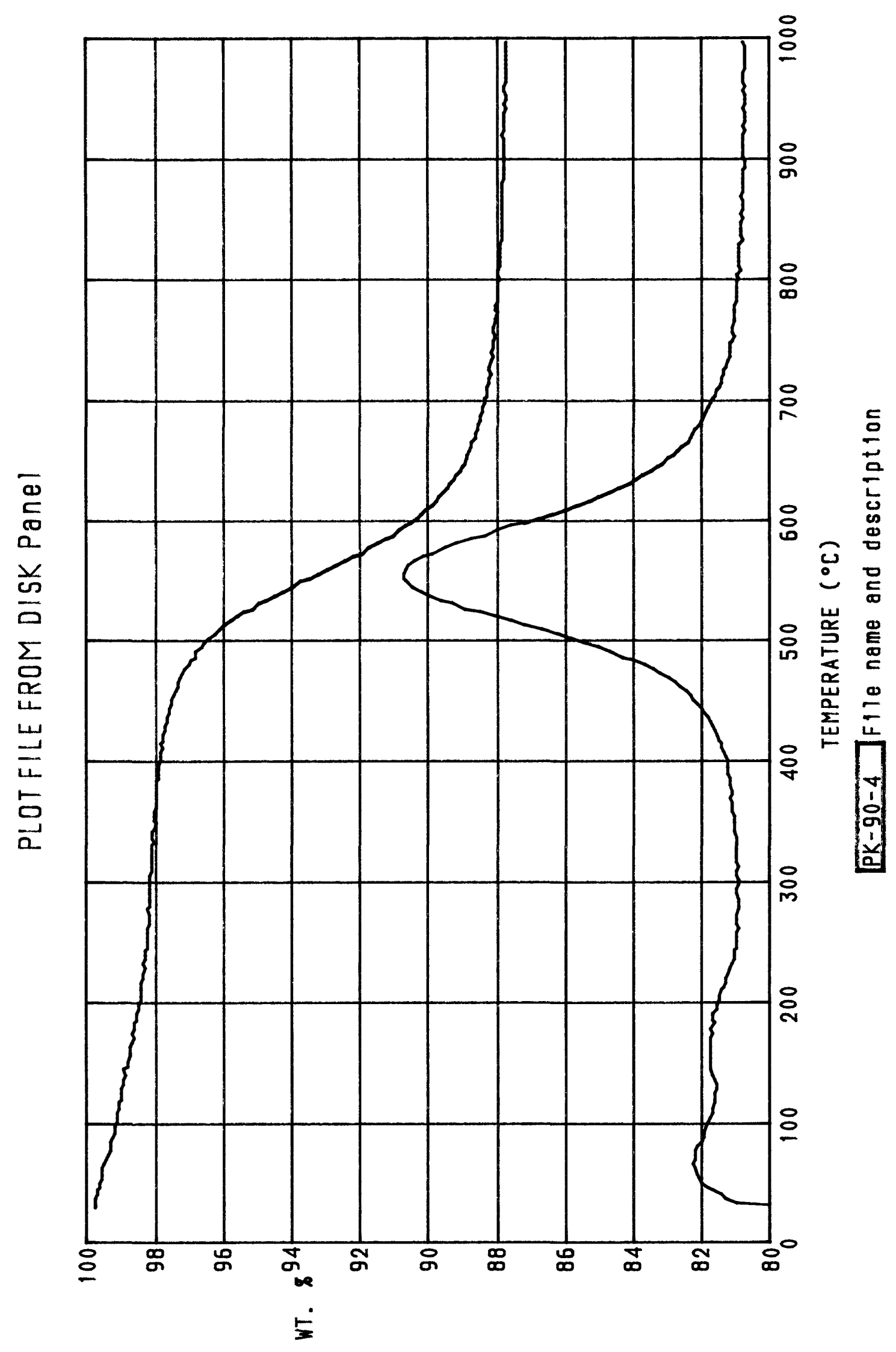




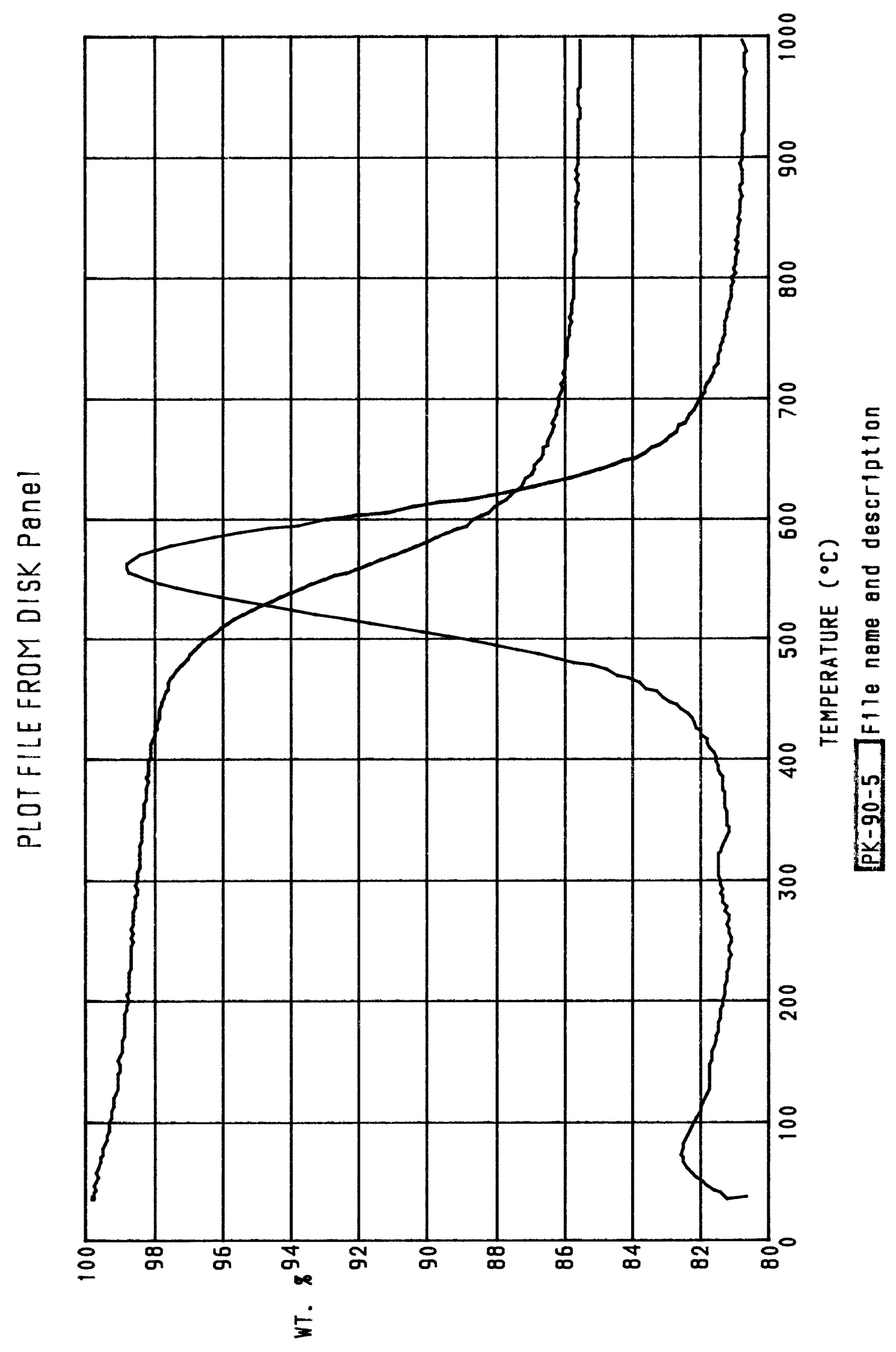




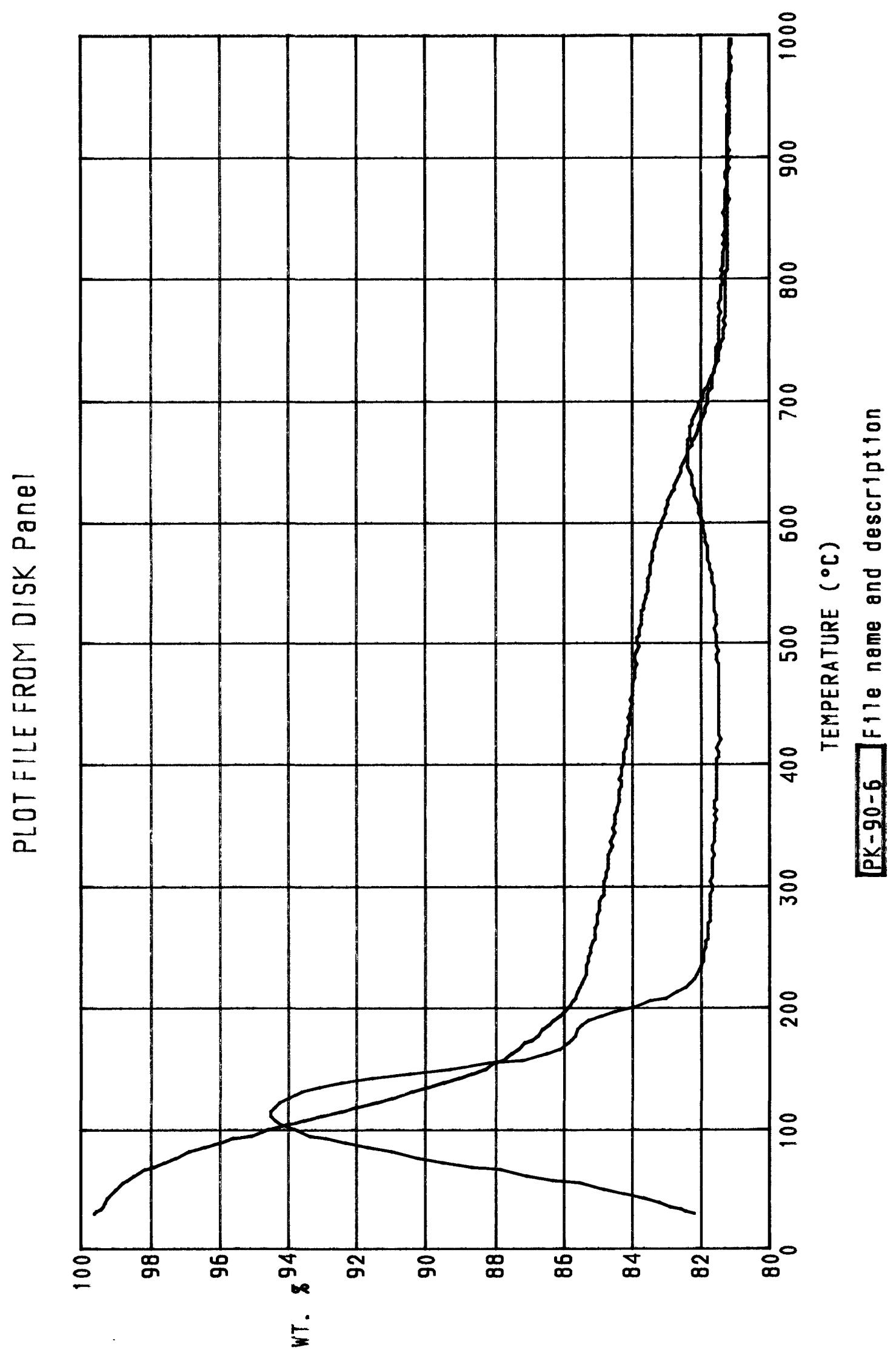




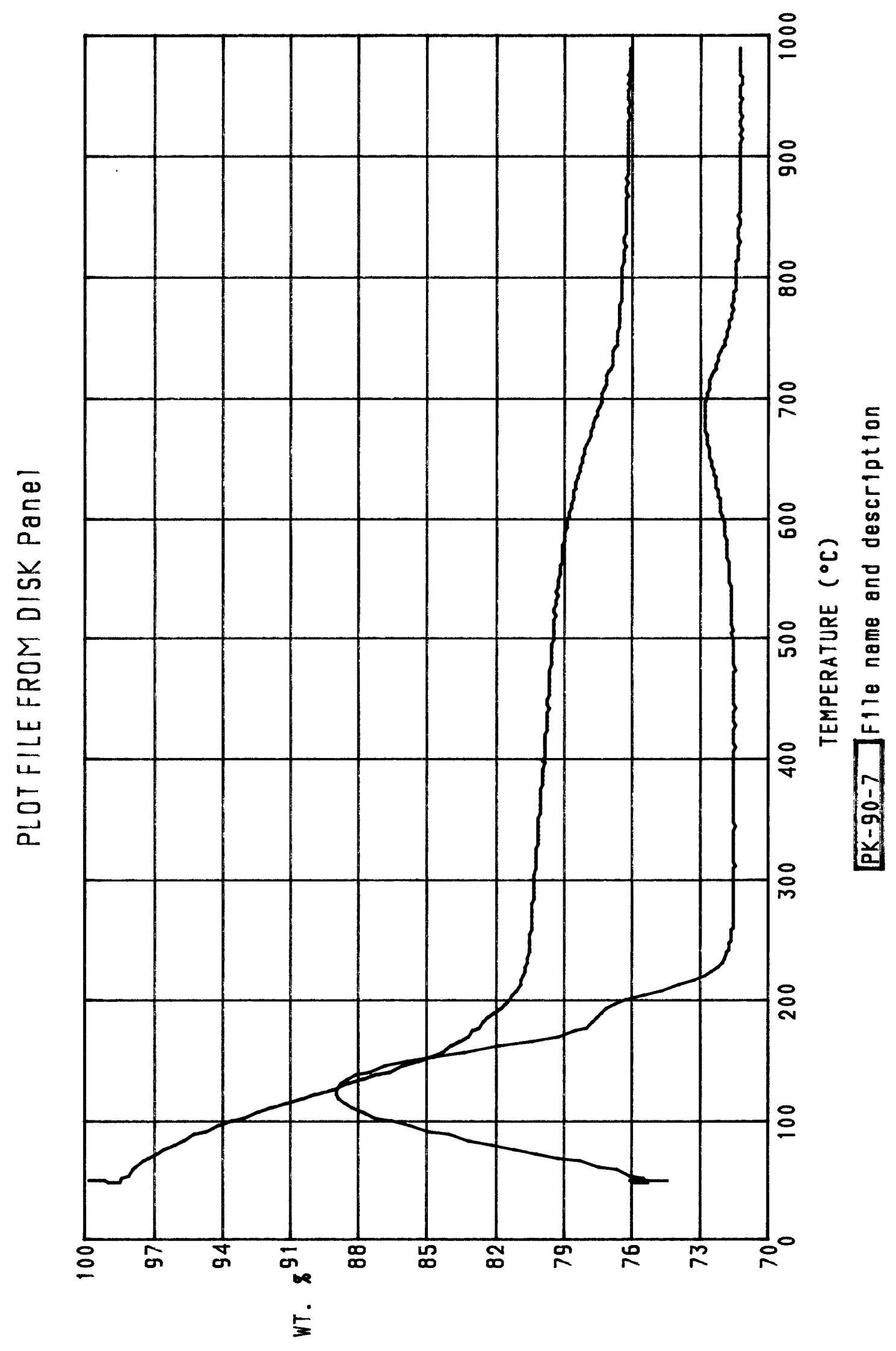




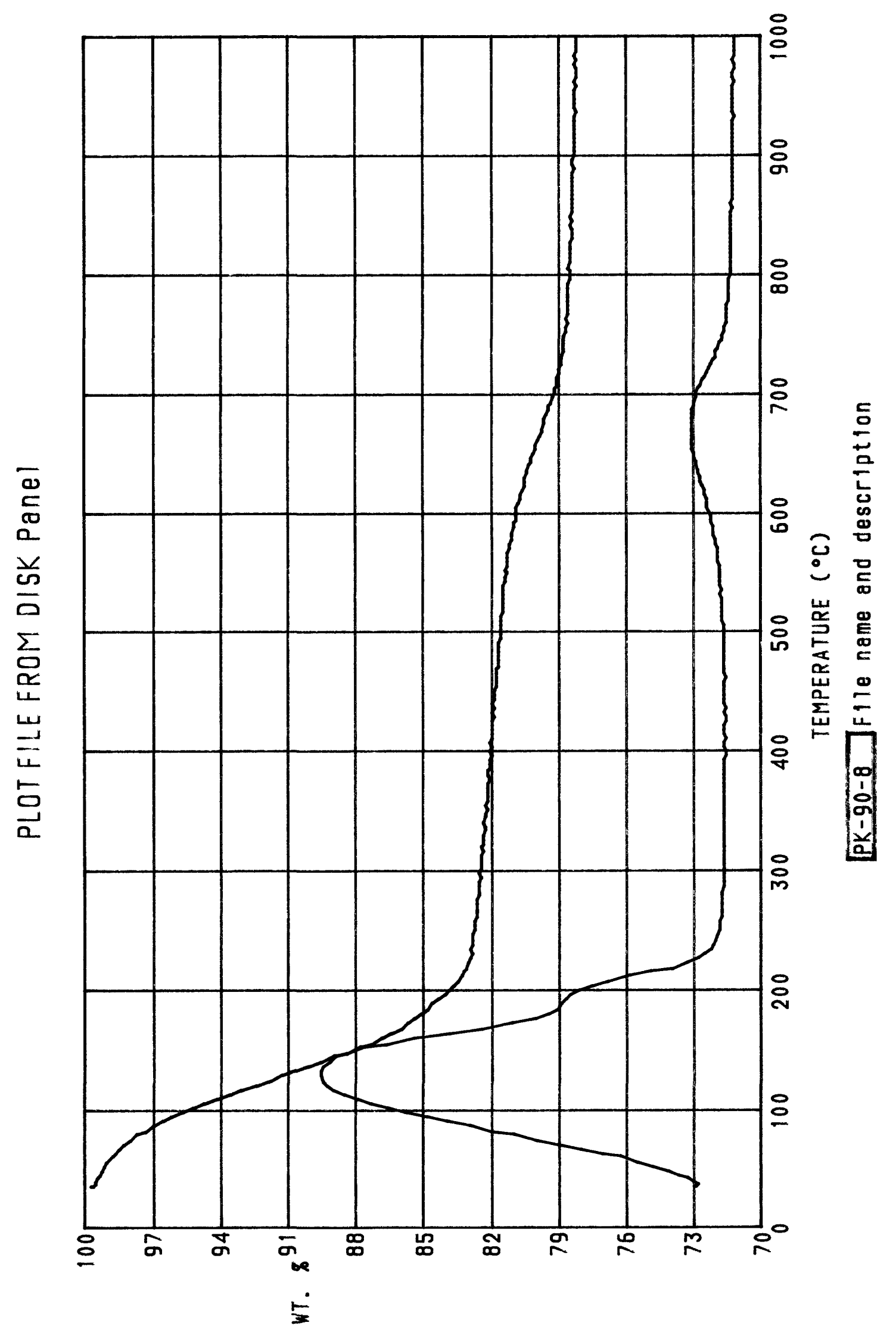




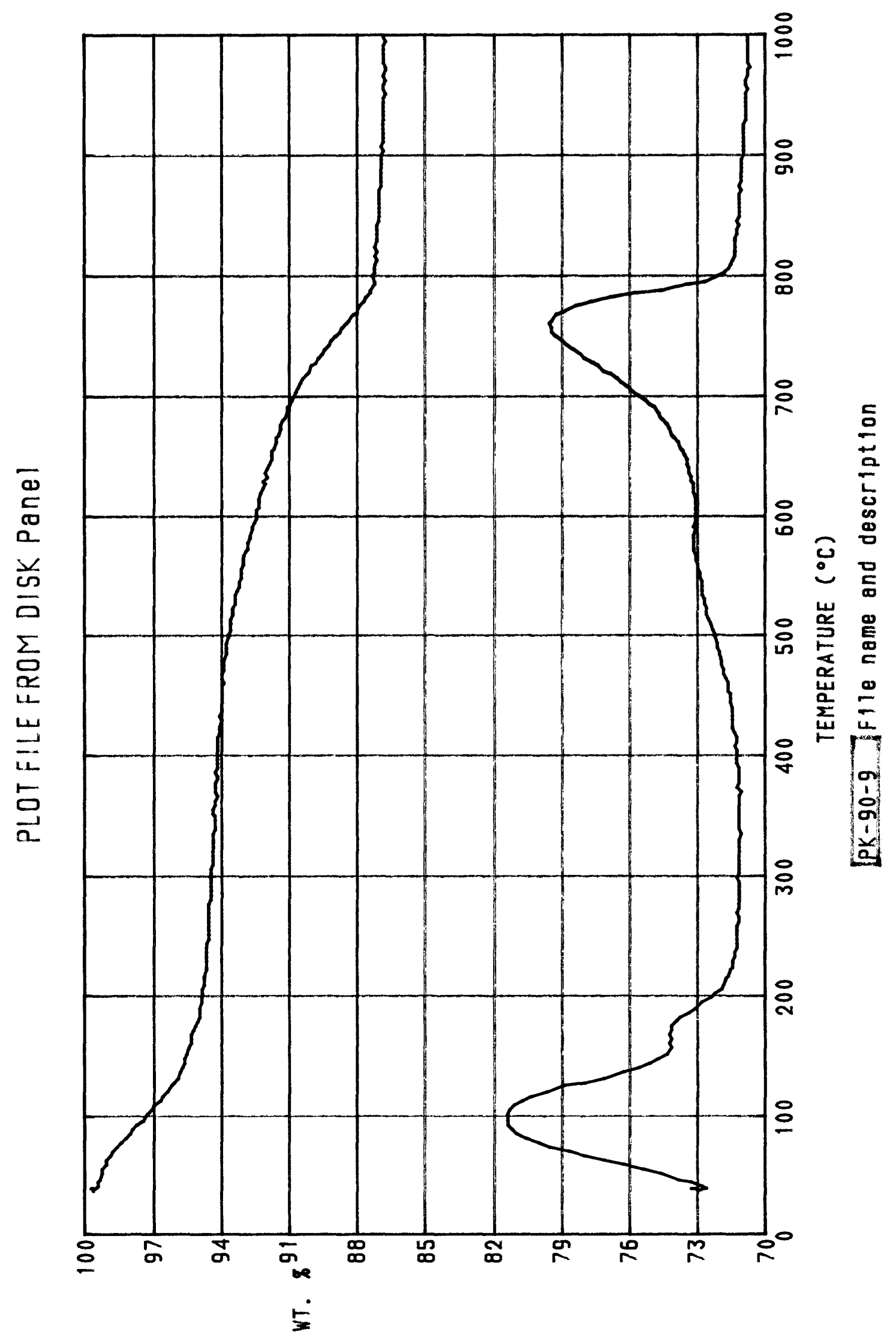




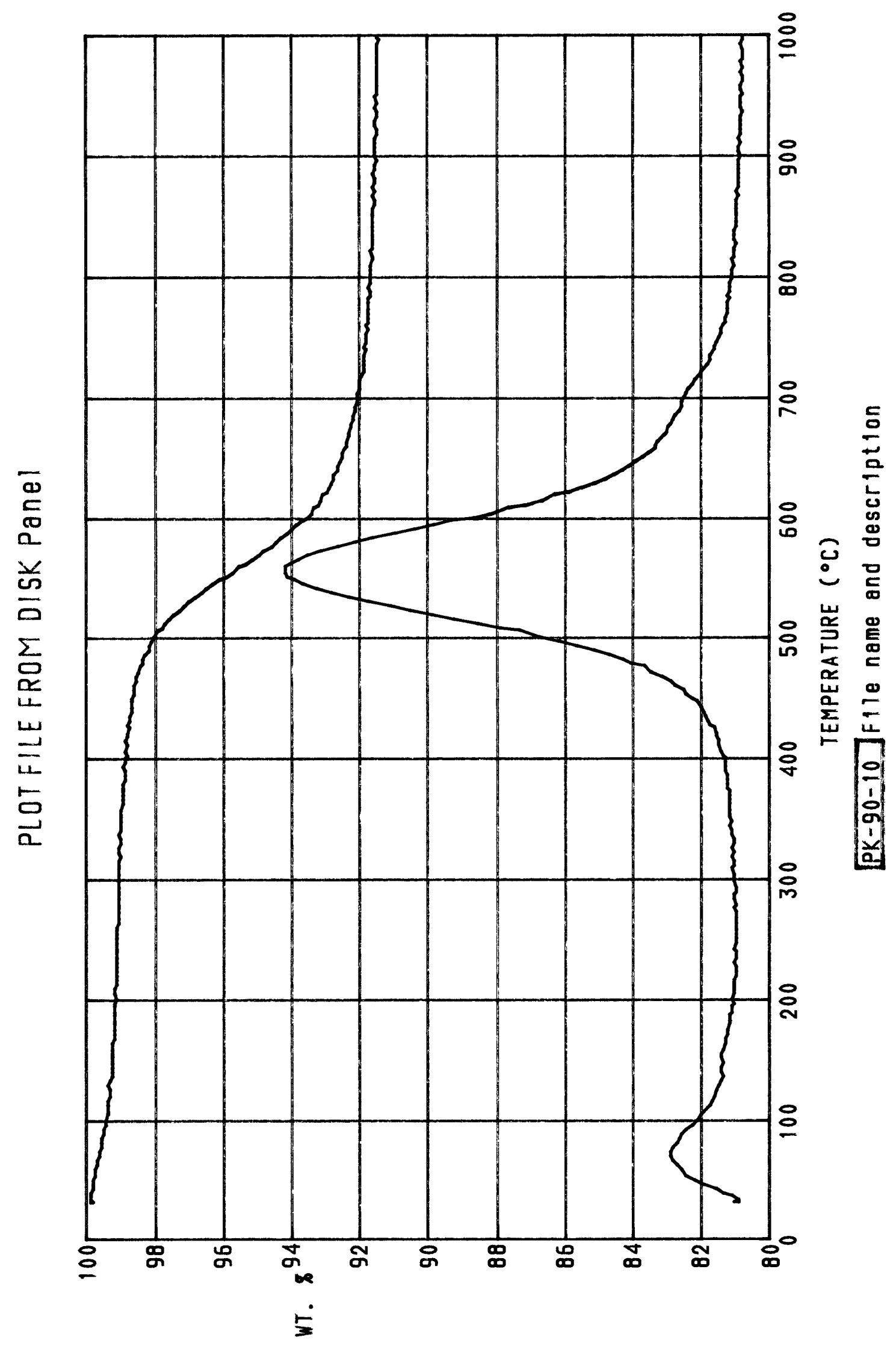




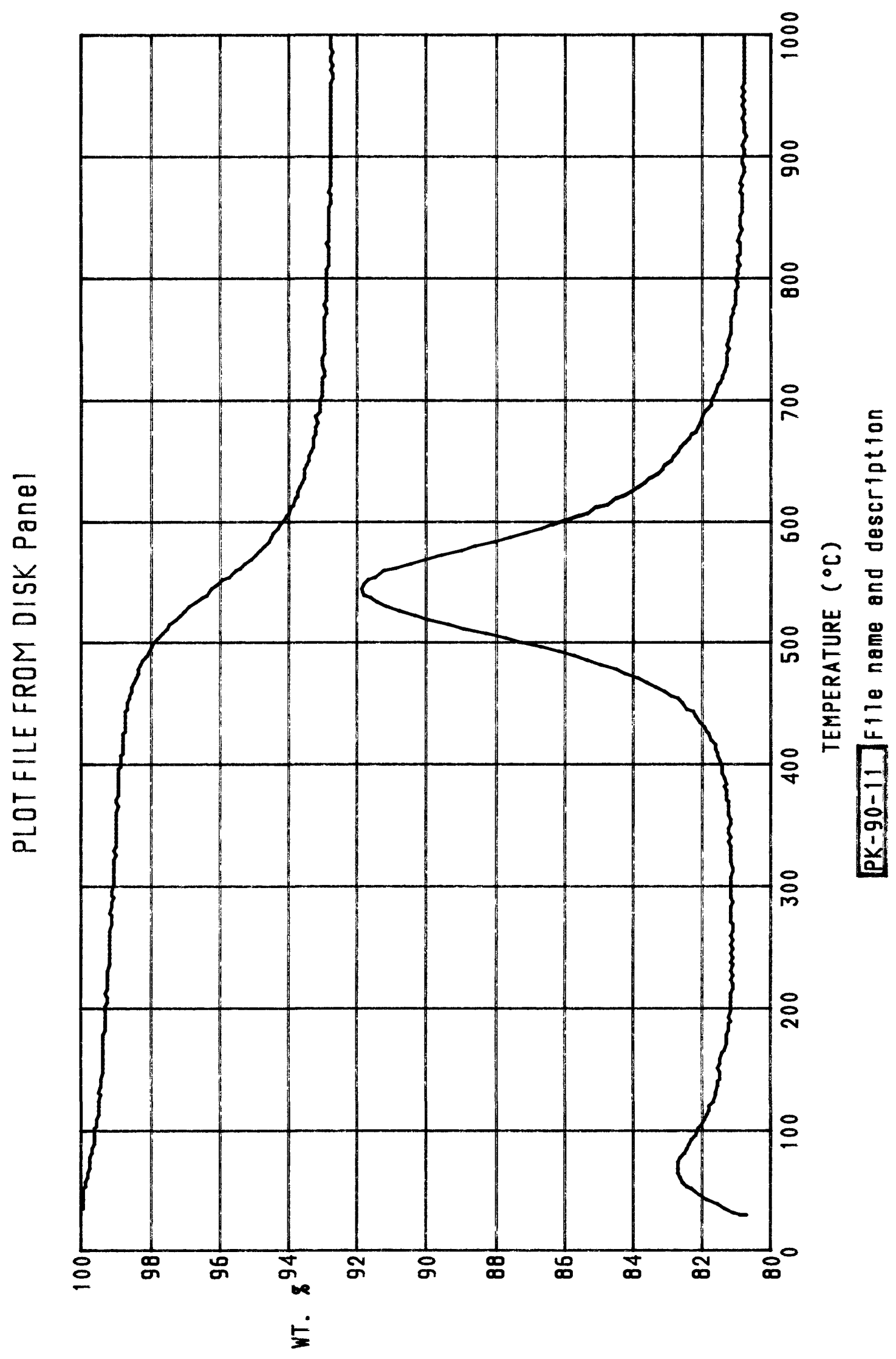




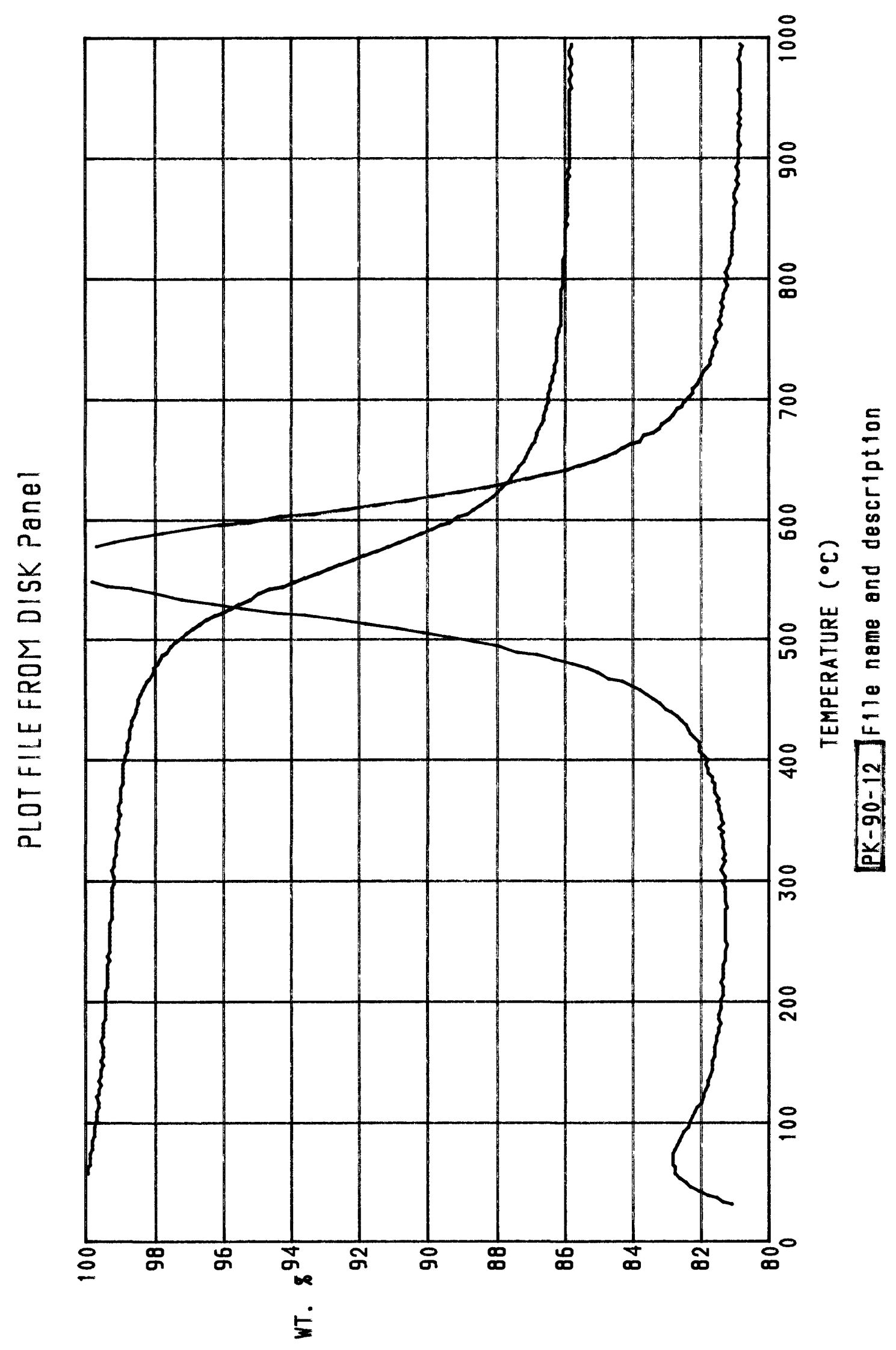




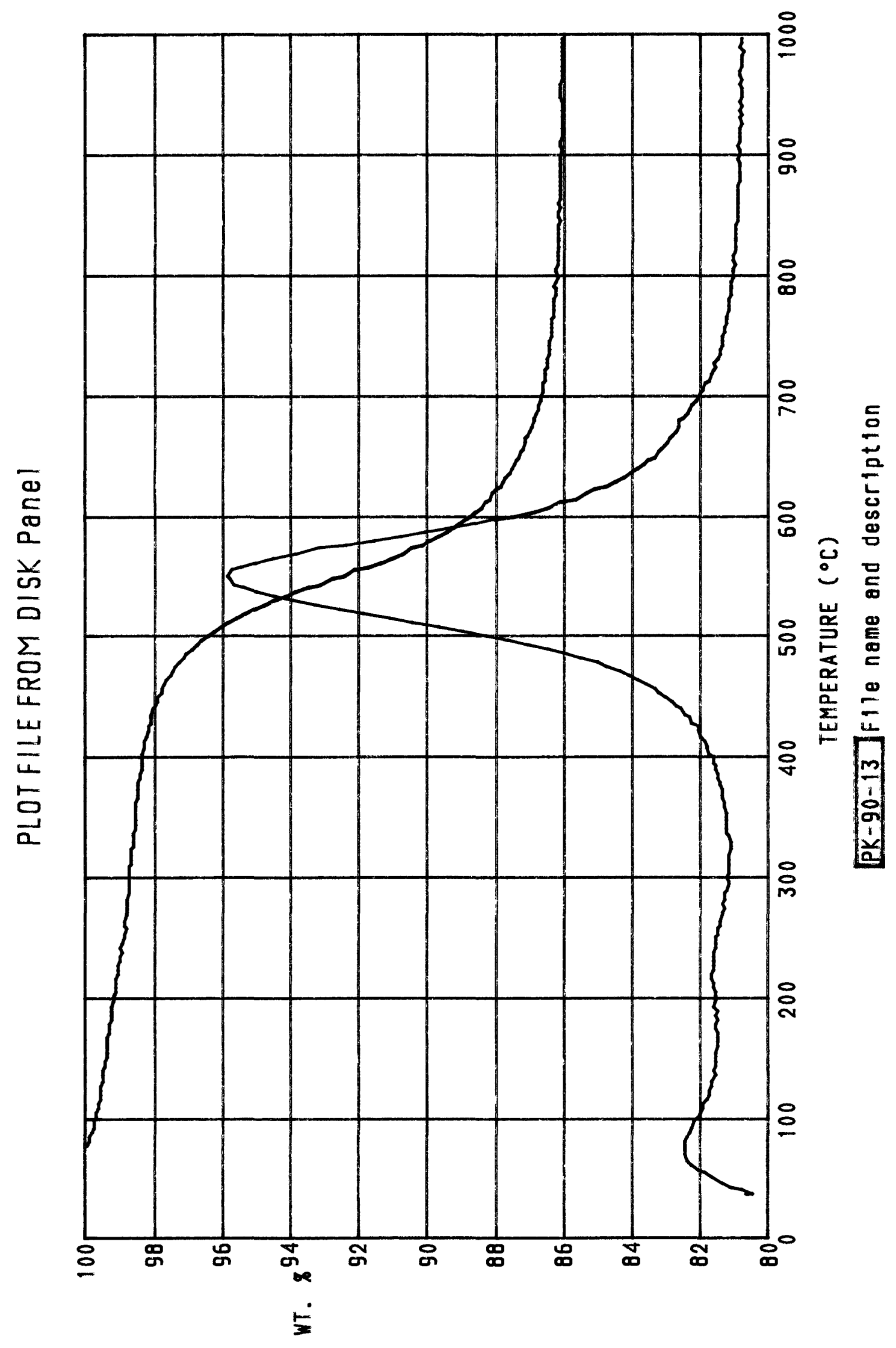




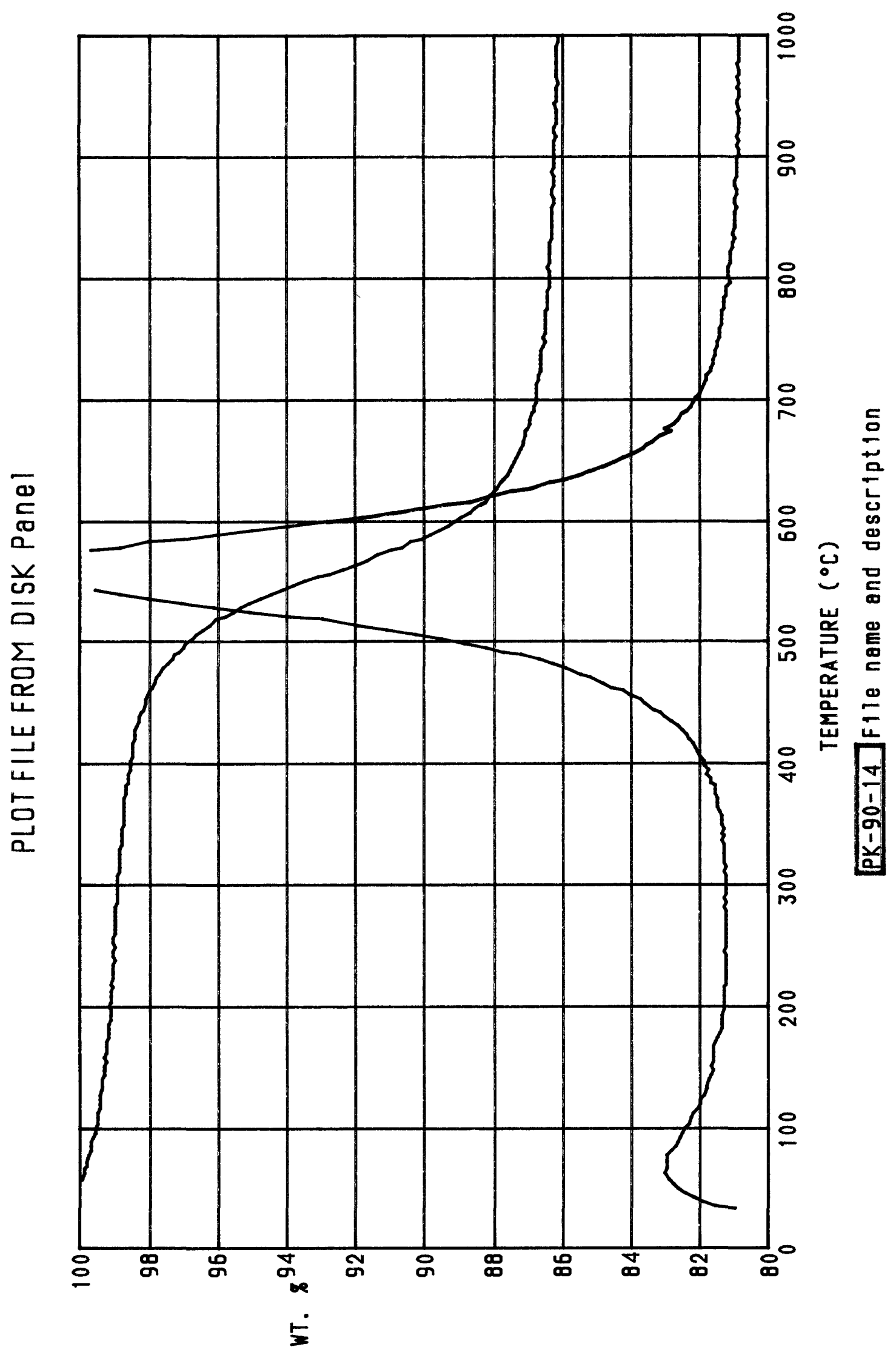




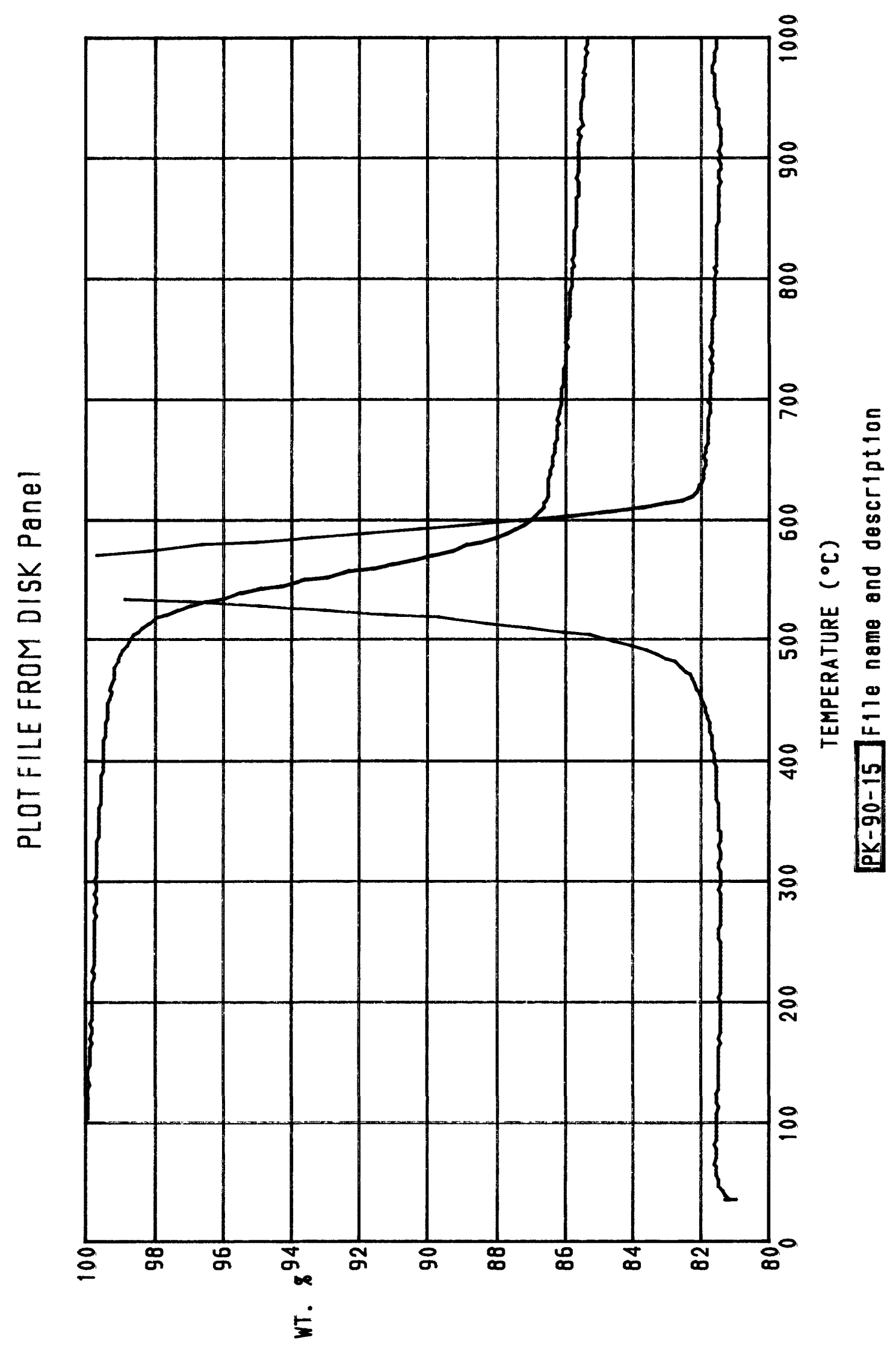




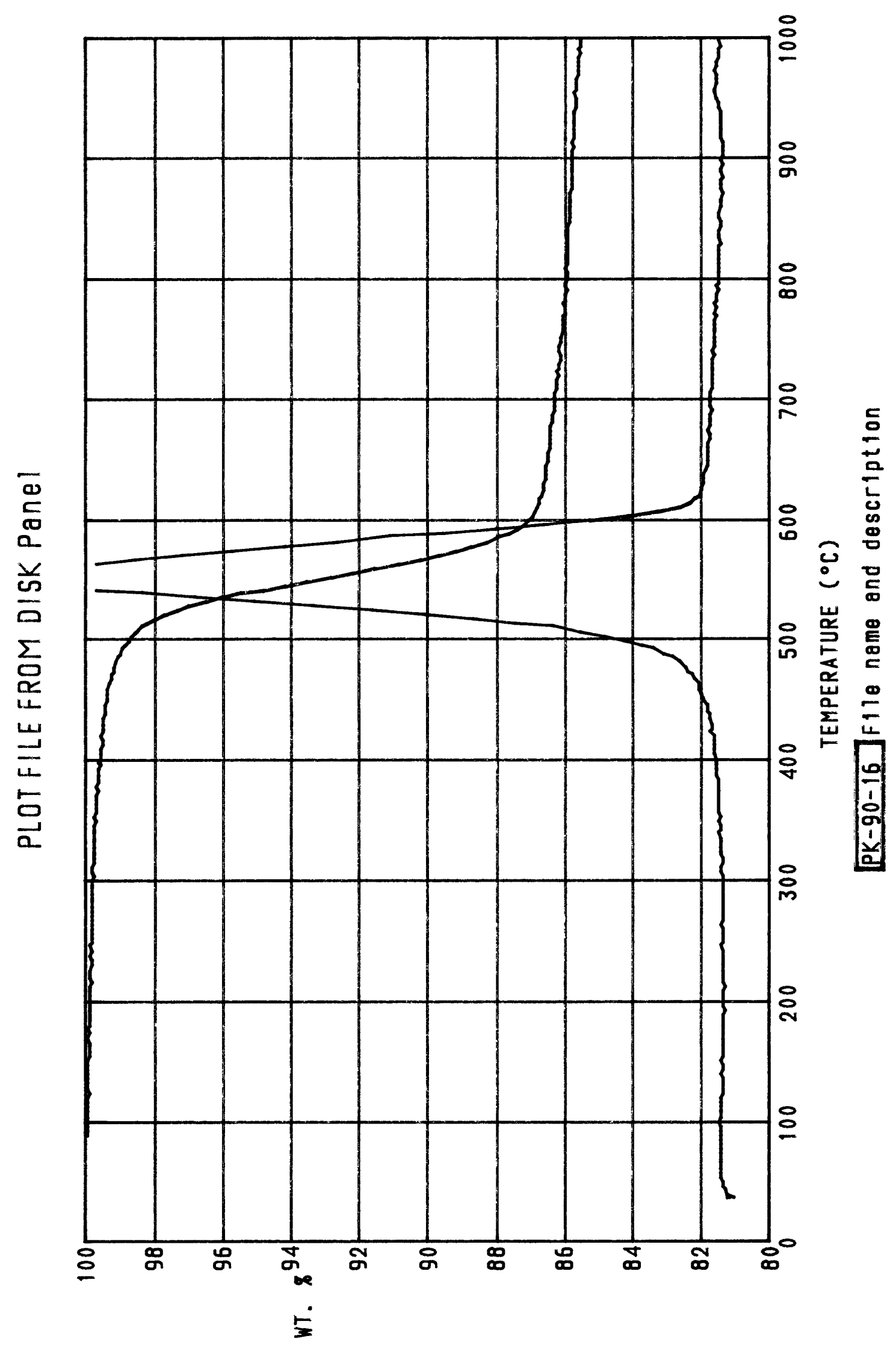




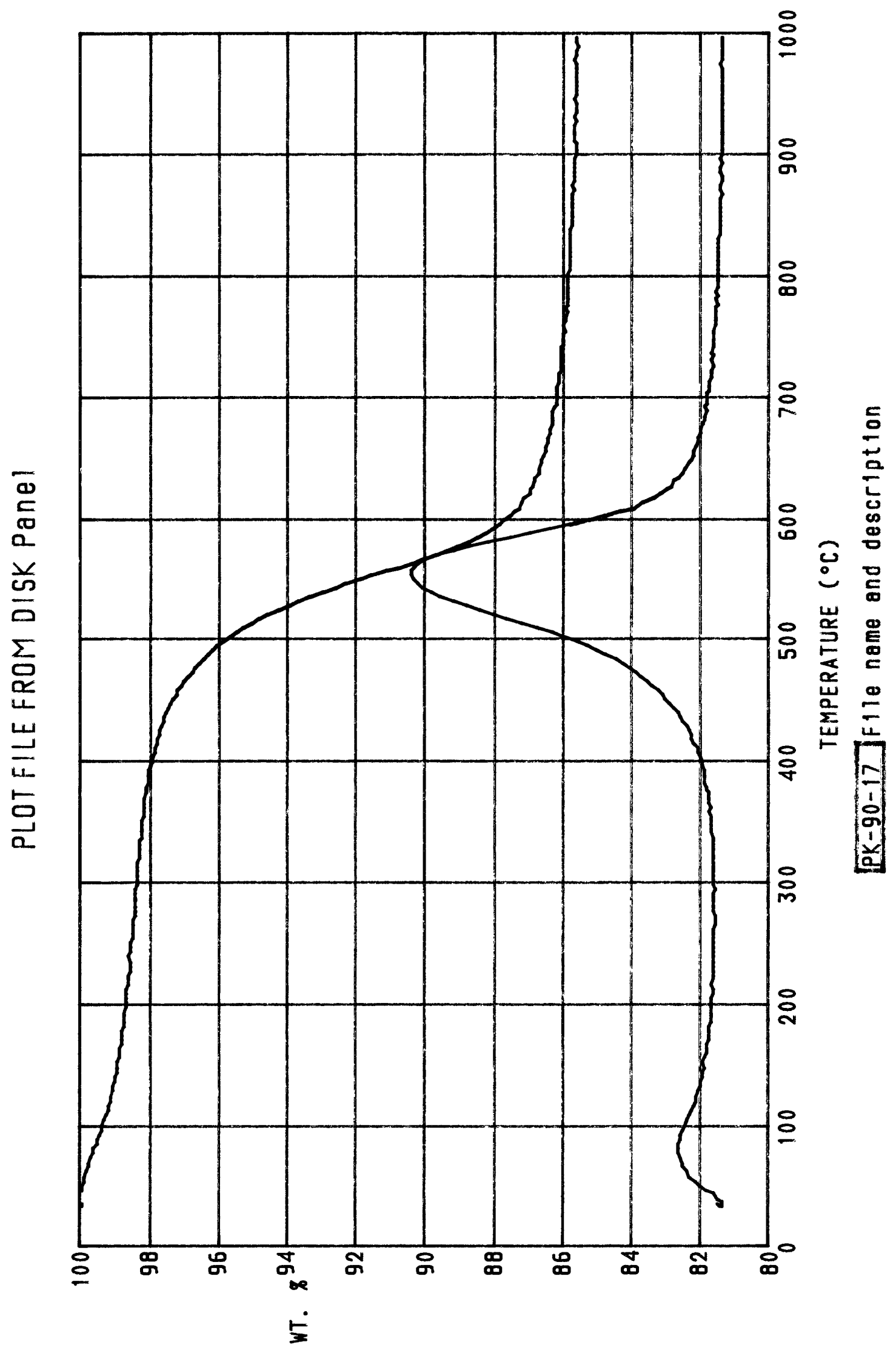

